WATER-QUALITY APPRAISAL OF NASQAN STATIONS

BELOW IMPOUNDMENTS, EASTERN TENNESSEE

R.D. Evaldi and J.G. Lewis

U.S. GEOLOGICAL SUR VEY

Water-Resources Investigations Report 85-4171

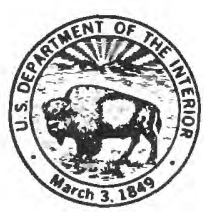

Knoxville, Tennessee 
UNITED STATES DEPARTMENT OF THE INTERIOR

DONALD PAUL HODEL, Secretary

GEOLOGICAL SUR VEY

Dallas L. Peck, Director

For additional information

Copies of this report can be write to: purchased from:

District Chief

U.S. Geological Survey

A-413 Federal Bidg.

Nashville, TN 37203
Open-File Services Section

U.S. Geological Survey

Box 25425, Federal Center

Lakewood, CO 80225 


\section{CONTENTS}

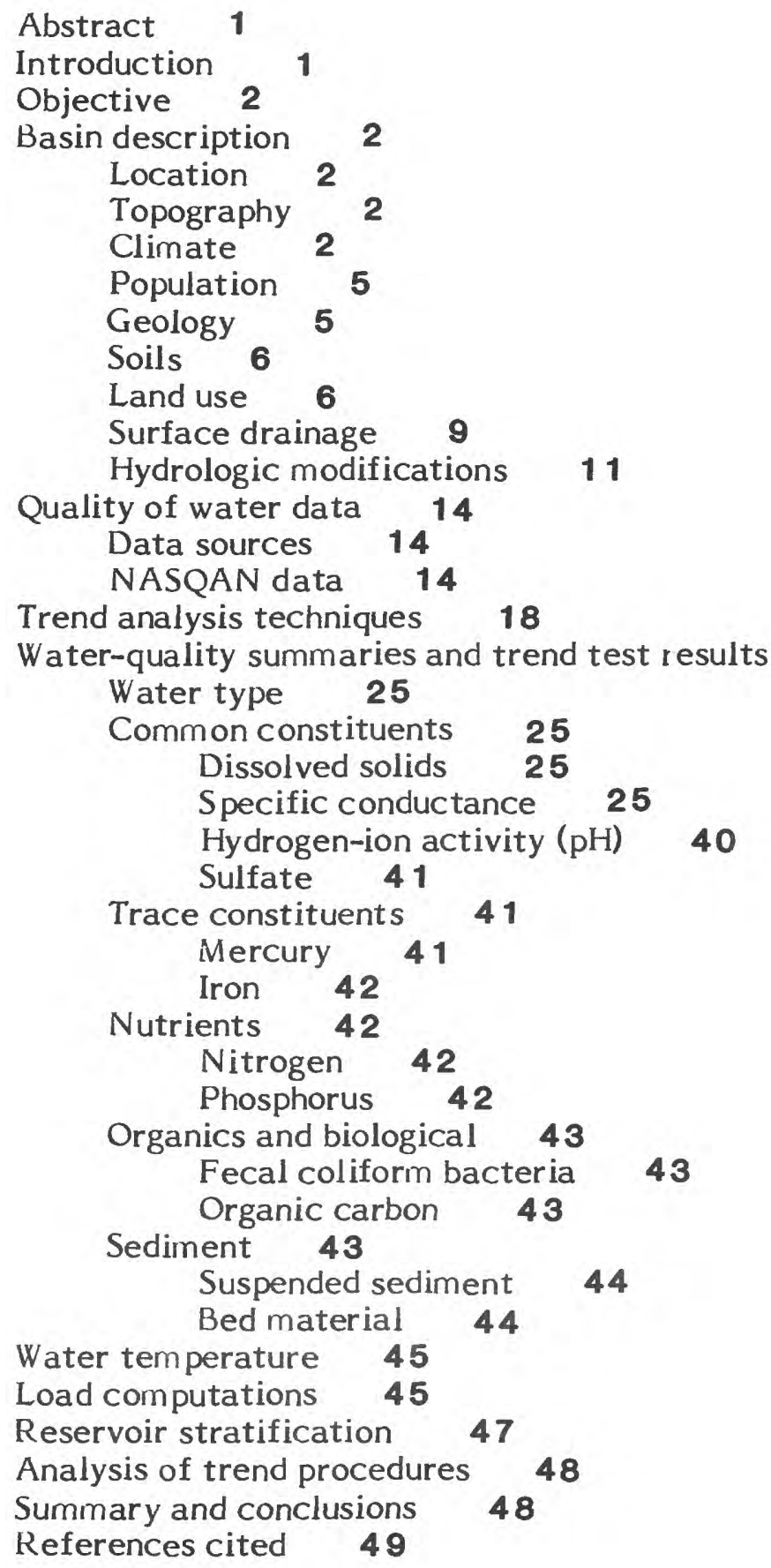




\section{ILLUSTRATIONS}

Figure 1-4. Maps showing:

1. Location of the study area and relation to physiographic provinces

2. Generalized geology and cross section of the NASQAN accounting unit above Watts Bar Dam 4

3. Generalized soils of the NASQAN accounting unit above Watts Bar Dam 7

4. Land use and land cover of the NASQAN accounting unit above Watts Bar Dam

5. Graph showing July to Junecoal production in the 15-county study area from 1971 through $1983 \quad 9$

6. Map showing principal sub-basins and drainage networks of the NASQAN a ccounting unit above Watts Bar Dam 10

7. Graph showing discharge and specific conductance of releases from Melton Hill Dam and Watts Bar Dam on September 1-3, 1981

8. Map showing wastewater discharge sites in the NASQAN accounting unit above Watts Bar Darn 13

9. Map showing hydrologic data-collection sites in the NASQAN accounting unit above Watts Bar Dam 17

10. Graphs showing specific-conductance profiles of the main-channel system in the NASQAN accounting unit above Watts Bar Dam

11. Graph comparing estimated water temperatures from harmonic analyses to the average observed water temperatures at the Watts Bar and Melton Hill NASQAiN stations

46

\section{TABLES}

Table 1. Population of Tennessee and counties upstream

of Watts Bar Reservoir in East Tennessee

\section{5}

2. Average discharge of main-channel stations at and above Watts Bar Dam

3. Flow duration of releases from Tennessee River and Clinch River Dams

4. Hydrologic data stations in the study area 15

5. Daily specific conductance, in microsiemens per centimeter at $25^{\circ} \mathrm{C}$, that was equaled or exceeded for the indicated percentage of time at the Melton Hill and Watts Bar NASQAN stations 18

6. Results of trend tests of discharge and specific conductance obtained at daily record stations at or above Watts Bar Dam during the 1972-82 water years 19

7. Median value of selected water-quality parameters and number of samples obtained at stations in the sub-basins of the study area during the 1972-82 water years 20

8. Summaries of selected constituent values obtained in sub-basins above Watts Bar Darn during the 1972-82 water years 22

9. Summary of water-quality parameters obtained at main-channel stations at or above Watts Bar Dam during the 1972-82 water years 26

10. Summary of trace-constituent data obtained at main-channel stations at or above Watts Bar Darn during the 1972-82 water years 
Table 11. Trends in water-quality parameters obtained at main-channel stations at or above Watts Bar Dam 32

12. Mean values of milliequivalent ratios expressed as percentage of cations $(\mathrm{Ca}+\mathrm{Mg}+\mathrm{Na}+\mathrm{K})$ or anions $\left(\mathrm{SO}_{4}+\mathrm{Cl}+\mathrm{HCO}_{3}+\mathrm{CO}_{3}\right)$

13. Trend test of percent composition data for the Watts Bar NASQAN station (site T19) 35

14. Regression statistics describing the relations between specific conductance and several water-quality parameters obtained at main-channel stations at or above Watts Bar Dam during the 1972-82 water years

37

15. Regression statistics describing the relations between daily specific conductance obtained at the Watts Bar NASQAN station and instantaneous specific-conductance observations obtained at main-channel stations above Watts Bar Dam

\section{0}

16. Sediment yield, accumulation, and outflow of Norris, Melton Hill, Fort Loudoun, and Watts Bar Reservoirs $\quad 43$

17. Mean concentrations of trace constituents in bed material samples obtained from streams above Watts Bar Dam during the period 1970-83

18. Harmonic analyses of stream temperature records of Melton Hill Darn and Watts Bar Dam

45

19. Load estimates of selected constituents sampled at the Watts Bar and Melton Hill NASQAN stations $\quad 47$

20. Water-quality parameters obtained the same day above and below Watts Bar Dam (sites T17 and T 19)

48

\section{FACTORS FOR CONVERTING INCH-POUND UNITS TO INTERNATIONAL SYSTEM OF (SI)}

\section{Multiply}

cubic foot per second $\left(\mathrm{ft}^{3} / \mathrm{s}\right)$

cubic foot per second per square $m$ ile $\left[\left(\mathrm{ft}^{3} / \mathrm{s}\right) / \mathrm{mi}^{2}\right]$

foot $(\mathrm{ft})$

mile (mi)

square mile $\left(\mathrm{mi}^{2}\right)$

pound (Ib)

ton, short
By

0.02832

0.01093

0.3048

1.609

2.590

0.4536

0.9072
To obtain

cubic meter per second $\left(\mathrm{m}^{3} / \mathrm{s}\right)$

cubic meter per second per square kilometer $\left[\left(\mathrm{m}^{3} / \mathrm{s}\right) / \mathrm{km}^{2}\right]$ meter $(\mathrm{m})$ kilometer $(\mathrm{km})$ square kilometer $\left(\mathrm{km}^{2}\right)$ kilogram (kg) metric ton

Temperature in degrees Fahrenheit $\left({ }^{\circ} \mathrm{F}\right)$ can be converted to degrees Celsius $\left({ }^{\circ} \mathrm{C}\right)$ as follows:

$$
{ }^{\circ} \mathrm{C}=\frac{{ }^{\circ} \mathrm{F}-32}{1.8}
$$




\title{
APPRAISAL OF WATER-QUALITY DATA FROM NASQAN STATIONS BELOW IMPOUNDMENTS, EASTERN TENNESSEE
}

\author{
by Ronald D. Evaldi and James G. Lewis
}

\section{ABSTRACT}

The National Stream Quality Accounting Network (NASQAN) is a network of stations at which systematic and continuing water-quality data are collected. Major objectives of this U.S. Geological Survey program are (1) to depict areal variability of streamflow and water-quality conditions nationwide on a year-by-year basis and (2) to detect long-term changes in streamflow and stream quality.

Several NASQAN stations in East Tennessee are downstream from impoundments which have a significant effect on water quality. NASQAN data obtained from the Tennessee River below Watts Bar Dam and the Clinch River below Melton Hill Dam were compared to water-quality data from the basins upstream. The comparison indicates that NASQAN data obtained below impoundments may not be adequate to describe a composite picture of water quality in the accounting unit. Detention time of storage in the impoundments is believed to moderate the range of constituent values observed at the NASQAN stations. Data obtained upstream and downstream from Watts Bar Dam indicate that the water sampled at the NASQAN station comes from stratified layers of the impoundment and is not representative of an integrated sample of water from the impoundment. Values of total recoverable iron suggest that, because of adsorption to sediments in impoundments, some constituents are not accurately described by sampling below impoundments.

Relations between water-quality constituents and flow at stations on the Clinch River and Tennessee River are not well defined due to regulation. Direct load computations for many constituents were therefore not possible, which diminished the utility of data from these NASQAN stations to account for quantity versus quality of the water. Load computations were only possible for ionic constituents through use of a continuous specific-conductance record as an intermediary. Compensation for the effects of discharge prior to application of the Seasonal Kendall test for trends could not be done and identification of trends in water-quality constituents caused by some process (source) change was not possible. Some water-quality trends indicated by data from the Clinch and Tennessee Rivers might reflect the decreasing trend in discharge during the 1972-82 water years. Thus the stations below Watts Bar Dam and below Melton Hill Dam do not adequately meet the NASQAN objective to detect and assess long-term changes in stream quality.

\section{INTRODUCTION}

The National Stream Quality Accounting Network (NASQAN) is a network of stations at which systematic and continuing water-quality data are collected. The major objectives of this U.S. Geological Survey program are:

(1) To obtain information on the quality and quantity of water moving within and from the United States through a systematic and uniform process of data collection, summarization, analysis, and reporting such that the data may be used for:

(2) Description of the areal variability of water quality in the Nation's streams through analysis of data from this and other programs.

(3) Detection of changes or trends with time in the pattern of occurrence of water-quality characteristics. 
(4) Providing a nationally consistent data base useful for watcr-quality assessments and hydrologic research.

The spacial distribution of NASQAN stations is based on a system of hydrologic subdivisions developed by the U.S. Water Resources Council and the Geological Survey. In this system, drainage basins in the United States are divided into 21 regions, 222 subregions, and 352 accounting units; the latter two divisions being progressively smaller parts of a region.

NASQAN stations generally are located at or near the most downstream point of accounting units. Some NASQAN sites are being operated downstream of impoundments. For example, all NASQAN stations in East Tennessee are located on highly regulated streams and several are located immediately below dams.

\section{OBJECTIVE}

The objective of this study was to describe the areal variability and long-term trends in water quality at NASQAN stations on the Tennessee River below Watts Bar Dam and the Clinch River below Melton Hill Dam in East Tennessee. The NASQAN station data was compared with the areal and temporal variability of water quality in the upstream NASQAN accounting unit. Comparison of NASQAN data obtained below an impoundment to water quality of the upstream basin will help to determine whether NASQAN stations located on regulated stream systems provide a composite picture of water quality within the accounting unit. Constituent concentrations which might be expected in a free-flowing stream may be changed due to storage in the impoundments, and samples obtained below the impoundments may not adequately describe the water quality of the drainage basin.

\section{BASIN DESCRIPTION}

The Tennessee River at Watts Bar Dam is the outlet for all surface flow leaving the study area. The drainage area at the streamflowmeasuring and water-sampling station on the Tennessee River at Watts Bar Dam is $17,310 \mathrm{mi}^{2}$.
However, this study was restricted, in general, to the $2,201 \mathrm{mi}^{2}$ area above Watts Bar Dam that corresponds to the Area 19 hydrologic reporting area of the Eastern Coal province. This 2,201 $\mathrm{mi}^{2}$ is downstream from other impoundments of the NASQAN accounting unit. The following descriptive information about the study area was excerpted mainly from the Geological Survey publication "Hydrology of Area 19, Eastern Coal Province, Tennessee" (Gaydos and others, 1982).

\section{Location}

The study area, in eastern Tennessee, includes parts of 15 counties (fig. 1). This a rea lies in parts of two physiographic provinces, the Cumberland Plateau (a section of the Appalachian Plateau province) and the Ridge and Valley province.

\section{Topography}

The Cumberland Plateau, in the northwest part of the study area, has a general altitude of 1,500 to 1,700 feet and an area of more than $1,100 \mathrm{mi}^{2}$. The terrain is mostly rolling hills. However, a line of mountains near the eastern edge of the Cumberland Plateau is more than 1,000 feet higher than the surrounding plateau, and some streams have incised more than 600 feet below the plateau surface. Separating the Cumberland Plateau from the Ridge and Valley is a highly dissected southeast-facing escarpment which has 700 to 900 feet relief in most areas.

The Ridge and Valley, in the southeast part of the study area, is characterized by long ridges separated by valleys trending in a northeastsouthwest direction (figs. 1 and 2 ). These valleys are usually flat with a general altitude of 800 to 900 feet. Intervening ridges reach altitudes of 1,000 to 1,300 feet.

\section{Climate}

The study area is in parts of two climatological divisons, eastern Tennessee and the Cumberland Plateau. Mean annual precipitation is about 52 inches, with extremes ranging from 


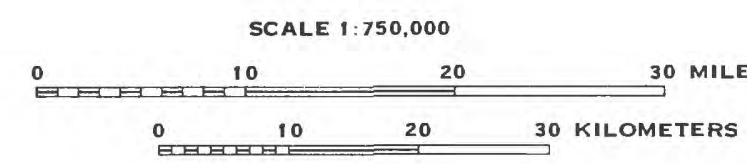

(1)

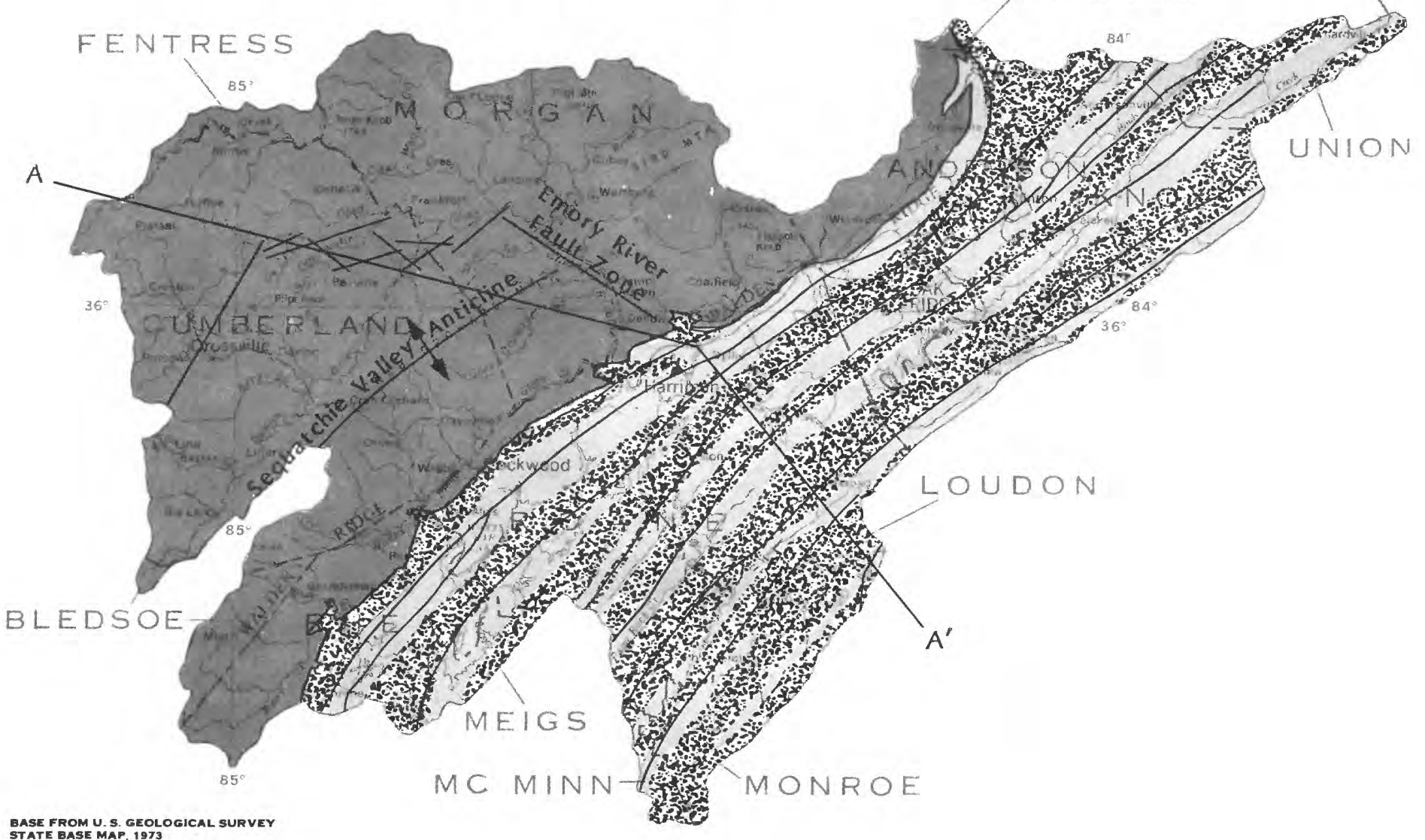

BASE FROM U. S. GEOLOGICAL SURVEY
STATE BASE MAP, 1973

\section{EXPLANATION}

Pennsylvanian rocks

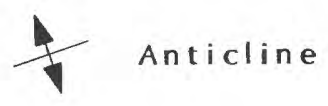

Pre-Pennsylvanian rocks

Fa u It

Karst areas

Contain sinkholes, caves, and disappearing streams

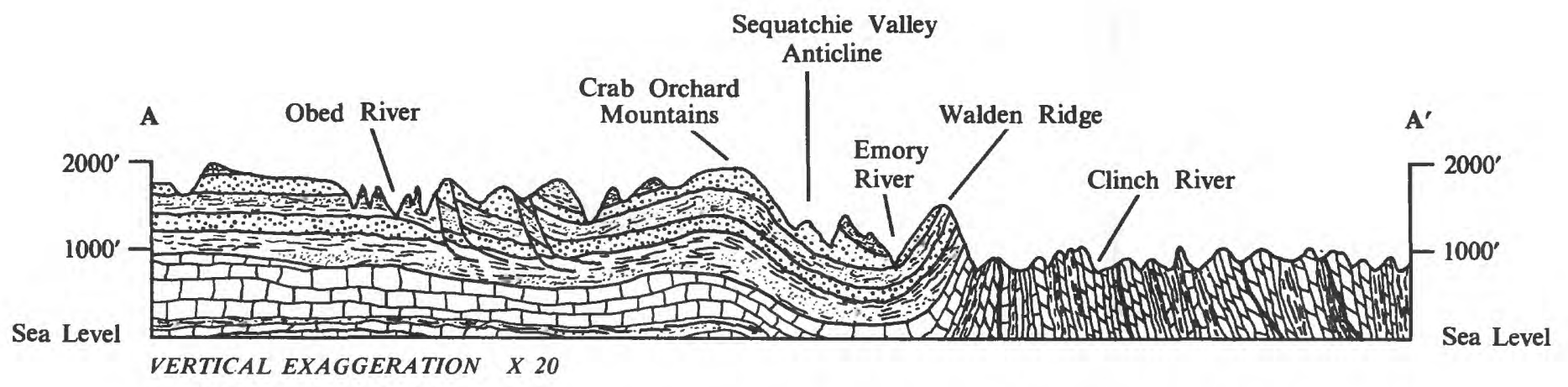

Figure 2.--Generalized geology and cross section of the NASQAN accounting unit above Watts Bar Dam (geology from W. D. Hardeman, 1966; karst areas from R. A. Miller and P. D. Sitterly, 1977). 
about 35 inches in dry years to about 70 inches in wet years (U.S. Department of Commerce, 1961). Average annual temperature is about $58^{\circ} \mathrm{F}$ with extremes seldom above $100^{\circ} \mathrm{F}$ or below $-5^{\circ} \mathrm{F}$.

\section{Population}

The 1980 population of the 15 counties, in which the study area is located, was 699,100 , or about 15 percent of the total population of Tennessee. This represents an increase of 26 percent over the 1960 population $(554,900)$. Several counties had a decrease in population between 1960 and 1970, but all showed a significant increase between 1970 and 1980. Distribution of the 1960,1970 , and 1980 population by counties is presented in table 1.

\section{Geology}

The Cumberland Plateau (fig. 2) is underlain by gently dipping Pennsylvanian sandstone and shale, some conglomerate, and coal, with a com- bined thickness of about 1,500 feet. These Pennsylvanian rocks overlie Mississippian carbonate rocks and are separated by the Pennington Formation of Mississippian age which is a transitional formation to the basal Pennsylvanian sandstone and shale. The Mississippian rocks are predominately limestone, calcareous shale, and siltstone with a maximum thickness of about 1,000 feet. These rocks crop out along the escarpment which separates the Cumberland Plateau from the Ridge and Valley. Chattanooga Shale of Devonian age and the Rockwood Formation of Silurian age underlie the Mississippian rocks and crop out along the base of the escarpment.

The Ridge and Valley is underlain by Ordovician and Cambrian rocks which are predominately carbonate, siltstone, shale, and some sandstone. Topographic relief consists of ridges underlain by resistant sandstone or cherty limestone, and valleys underlain by shale and soluble limestone. Formations within the Ridge and Valley have been deformed by folding and faulting (fig. 2).

Table 1.--Population of Tennessee and counties upstream of Watts Bar Reservoir in East Tennessee

[Source: U.S. Bureau of the Census]

\begin{tabular}{|c|c|c|c|c|c|}
\hline & 1960 & $\frac{\text { Year }}{1970}$ & 1980 & $\begin{array}{l}\text { Percent } \\
\text { change } \\
1960-70\end{array}$ & $\begin{array}{l}\text { Percent } \\
\text { change } \\
1970-80\end{array}$ \\
\hline Tennessee & $3,567,089$ & $3,926,018$ & $4,591,120$ & 10.0 & 16.9 \\
\hline Anderson & 60,032 & 60,300 & 67,346 & .4 & 11.6 \\
\hline Bledsoe & 7,811 & 7,643 & 9,478 & -2.1 & 24.0 \\
\hline Campbe11 & 27,936 & 26,045 & 34,923 & -6.7 & 34.1 \\
\hline Cumberland & 19,135 & 20,733 & 28,676 & 8.3 & 38.3 \\
\hline Fentress & 13,288 & 12,593 & 14,826 & -5.2 & 17.7 \\
\hline Grainger & 12,506 & 13,948 & 16,751 & 11.5 & 20.0 \\
\hline Knox & 250,523 & 276,293 & 319,694 & 10.2 & 15.7 \\
\hline Loudon & 23,757 & 24,266 & 28,553 & 2.1 & 17.6 \\
\hline McMinn & 33,662 & 35,462 & 41,878 & 5.3 & 18.0 \\
\hline Meigs & 5,160 & 5,219 & 7,431 & 1.1 & 42.3 \\
\hline Monroe & 23,316 & 23,475 & 28,700 & .6 & 22.2 \\
\hline Morgan & 14,304 & 13,619 & 16,604 & -4.7 & 21.9 \\
\hline Rhea & 15,863 & 17,202 & 24,235 & 8.4 & 40.8 \\
\hline Roane & 39,133 & 38,881 & 48,425 & -.5 & 24.5 \\
\hline Union & 8,498 & 9,072 & 11,707 & 6.7 & 29.0 \\
\hline
\end{tabular}


Karst topography occurs mainly in the Valley and Ridge section of the study area (fig. 2), and in the Sequatachie anticline area of the Cumberland Plateau.

\section{$\underline{\text { Soils }}$}

Soils of the Cumberland Plateau are predominately loamy and well-drained. Their thickness ranges from less than 1 foot to as much as 5 feet over most of the plateau. The potential for erosion is slight to moderate except on steep slopes where erosion can become severe if the vegetation cover is removed.

Soils of the Ridge and Valley are predominately clayey and loamy and are well drained to excessively drained. Their thickness ranges from 4 feet to more than 8 feet over most of the Ridge and Valley. These soils have a slight to moderate potential for erosion.

The soil associations of the study area are shown on figure 3. Also presented on figure 3 is a description of the groups of soils within each soil association.

\section{Land Use}

Changes in land use may alter infiltration and runoff rates as well as the quality of the water draining from the basin. Land use and land cover for the study area is shown in figure 4. The locations of coal-mining activities are based on permits issued by the Tennessee Division of Conservation since 1972. Locations of mine sites abandoned prior to 1972 or unlicensed mine sites are unknown.

Urban development reduces the amount of infiltration, increases runoff rates, and may adversely affect water-quality. Pollutants accumulate on urban surfaces, especially impervious areas which are subject to washoff by storm events. Automobile emissions, fertilizers applied to lawns, industrial effluents and many other pollutants are washed from the atmosphere or urban landscape into storm-drainage systems and eventually into streams.

Forest cutting may cause long-term changes in streamflow and water quality. Following forest cutting, streamflow increases and then declines with the logarithm of time as the forest regrows (Swift and Swank, 1981). Much of the tree harvesting activity can lead to soil disturbance. This, coupled with steep terrain and storm runoff, makes erosion and the transport of sediment to surface streams highly probable. Logging activities around streams may result in debris being left in streams that can lead to bank erosion, leaching of toxic compounds, biodegradation of organic matter, and a general reduction in the dissolved oxygen level (U. S. Environmental Protection Agency, 1976a).

Agricultural activities can affect water quality. In a study involving rural areas of North Carolina, Simmons and Heath (1979) stated activities that most likely affect water quality include:

1. The use of fertilizers and pesticides on row crops and pastures,

2. Pollution from farm animals, especially cattle and poultry,

3. Pollution originating from septic tanks used for the disposal of domestic wastes, and

4. Exposure of the land to erosion during cultivation of fields and land clearing for buildings, roads, or other developments.

The first three activities generally increase concentrations or densities of select water-quality constituents leaving a drainage basin. While the last activity is expected to increase concentrations of suspended sediment and constituents sorbed on or in some way associated with sediment.

Construction and surface-mining activities, though not as wide-spread as agricultural activities, can yield large quantities of sediment to nearby waterways, causing severe adverse effects (EPA, 1976b). In addition to the sediment, contamination of streams draining strip-mined coal areas generally results from overland runoff or ground-water seepage contacting iron-sulfur compounds or minerals and introducing deleterious chemicals into solution (Bevans, 1980). Annual coal production for the years 1971-83 of the 15 county study area is shown in figure 5 . Production exhibited an increasing trend from 1973 through 1977 and a decreasing trend from 1978 into 1983. 


\section{FENTRESS}

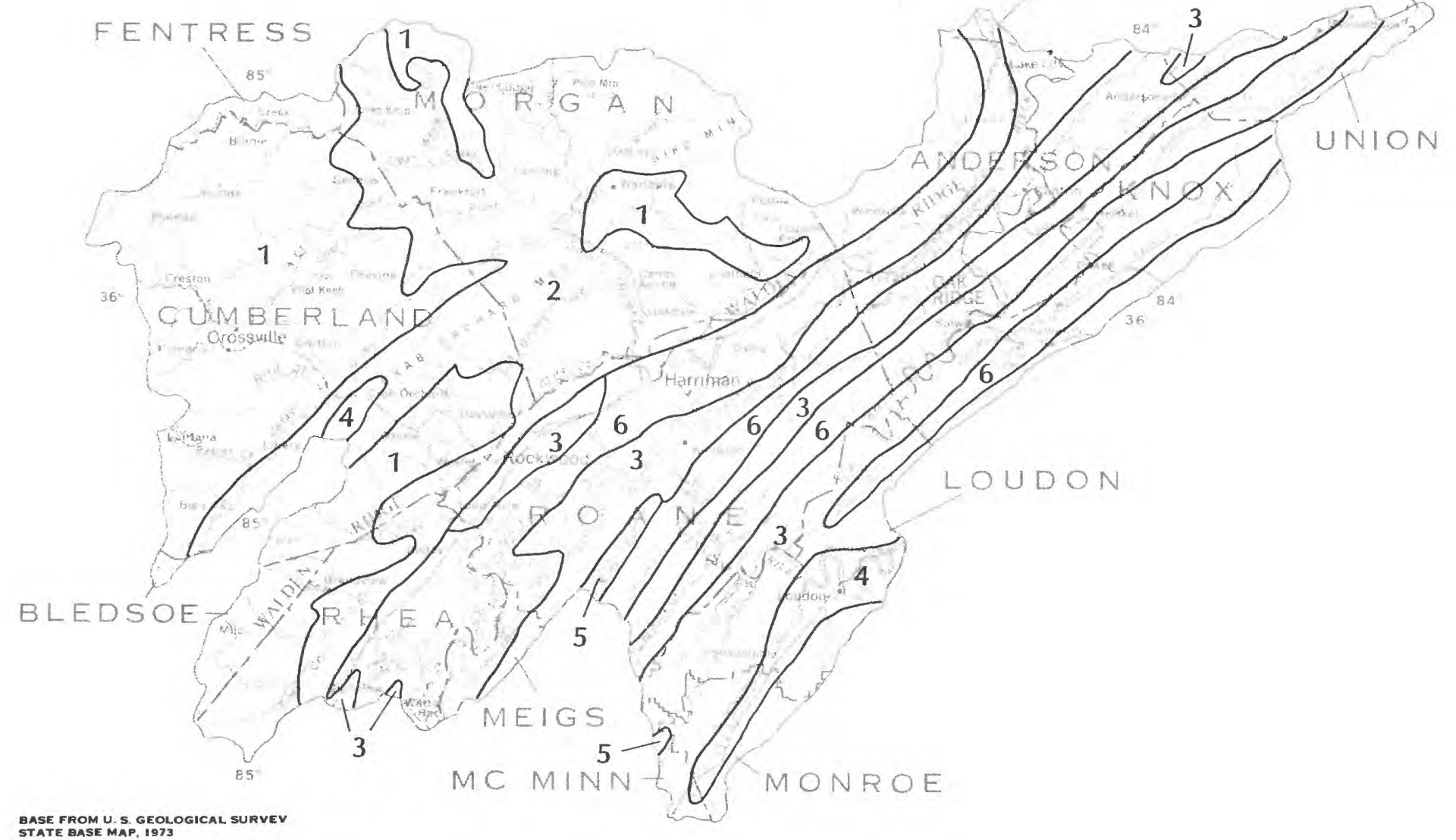

Map reference number Soil association

\section{Description}

\begin{tabular}{|c|c|c|}
\hline \multirow{2}{*}{1} & Hartsells-Lonewood- & $\begin{array}{l}\text { Moderately deep, well-drained, loamy soils } \\
\text { from sandstone and shale }\end{array}$ \\
\hline & $\begin{array}{l}\text { Hartsells-Ramsey- } \\
\text { Gilpin }\end{array}$ & $\begin{array}{l}\text { Moderately deep to shallow. well-drained. } \\
\text { loamy soils from sandstone and shale }\end{array}$ \\
\hline \multirow{3}{*}{2} & Bouldin-Ramsey & $\begin{array}{l}\text { Well-drained, stony and loamy soils with rock } \\
\text { outcrops from colluvium sandstone and shale }\end{array}$ \\
\hline & $\begin{array}{l}\text { Ramsey-Hartselis- } \\
\text { Grimsley-Gilpin }\end{array}$ & $\begin{array}{l}\text { Well-dramed stony and loamy soils from } \\
\text { sandstone and shale }\end{array}$ \\
\hline & $\begin{array}{l}\text { Muskıngum-Gilpin- } \\
\text { Jefferson }\end{array}$ & $\begin{array}{l}\text { Well-drained. loamy solls from shale and } \\
\text { sandstone }\end{array}$ \\
\hline \multirow{2}{*}{3} & Fullerton-Dewey & $\begin{array}{l}\text { Deep. well-drained. cherty and clayey soils } \\
\text { from dolomite and limestone }\end{array}$ \\
\hline & Fullerton-Bodine & $\begin{array}{l}\text { Deep, well-drained. cherty and clayey soils } \\
\text { from dolomite and limestone }\end{array}$ \\
\hline \multirow{2}{*}{4} & $\begin{array}{l}\text { Decatur-Dewey- } \\
\text { Waynesboro }\end{array}$ & $\begin{array}{l}\text { Deep. well-drained. clayey soils from } \\
\text { alluvium and limestone }\end{array}$ \\
\hline & $\begin{array}{l}\text { Waynesboro-Etowah- } \\
\text { Sequatchie-Allen }\end{array}$ & $\begin{array}{l}\text { Deep well-drained, clayey and loamy soils } \\
\text { from alluvium and colluvium }\end{array}$ \\
\hline 5 & Talbott-Etowah & $\begin{array}{l}\text { Shallow to deep well-draıned clayey and } \\
\text { loamy soils with rock outcrops from shale } \\
\text { and lirnestone }\end{array}$ \\
\hline 6 & $\begin{array}{l}\text { Wallen-Talbott- } \\
\text { Montevallo }\end{array}$ & $\begin{array}{l}\text { Shallow to moderately deep, excessively to } \\
\text { well-dramed stony and clayey soils from } \\
\text { sandstone shale and limestone }\end{array}$ \\
\hline
\end{tabular}

Figure 3.--Generalized soils of the NASQAN accounting unit above Watts Bar Dam (soils from J.A. Elder and M. E. Springer, 1978). 


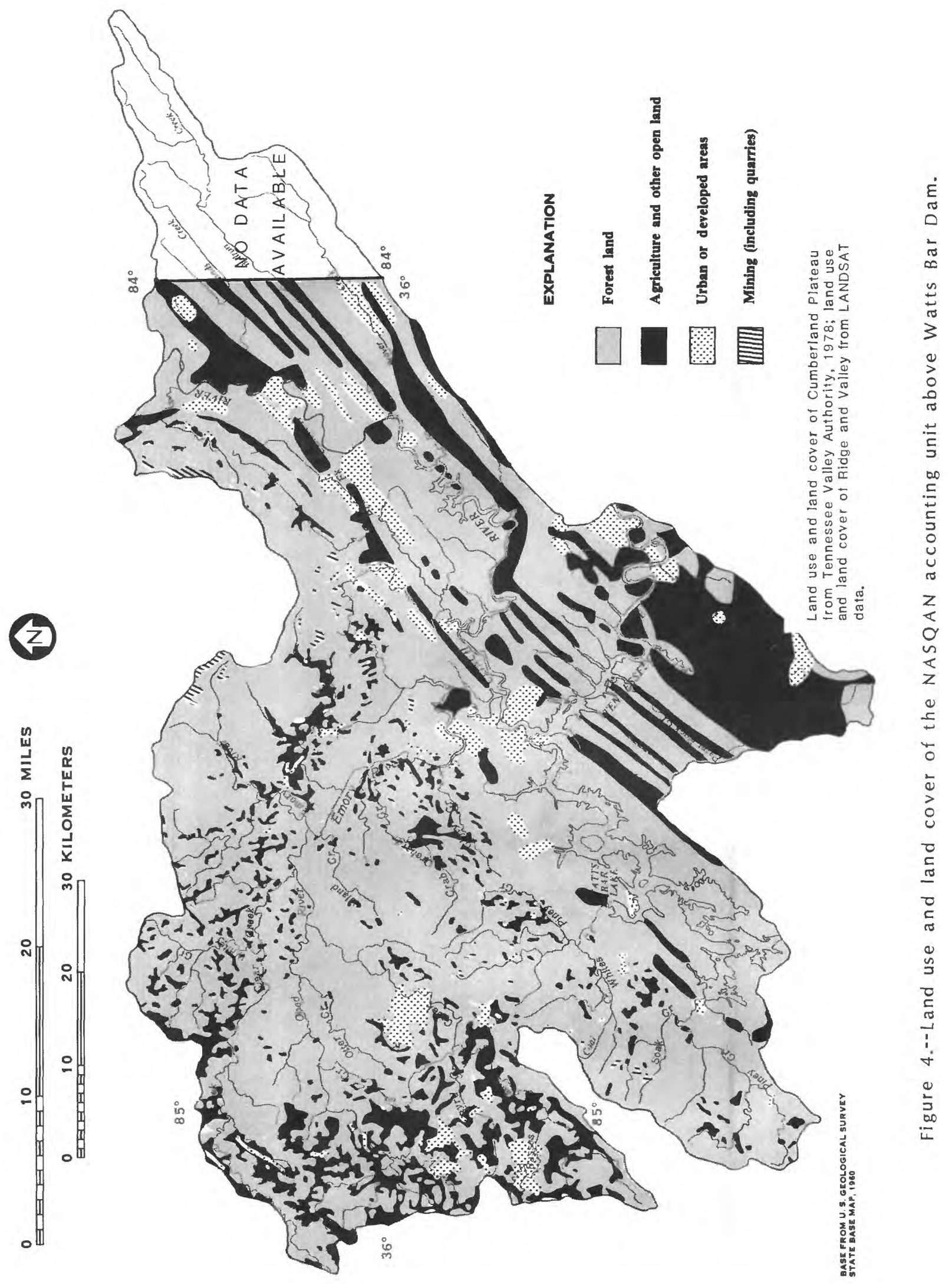




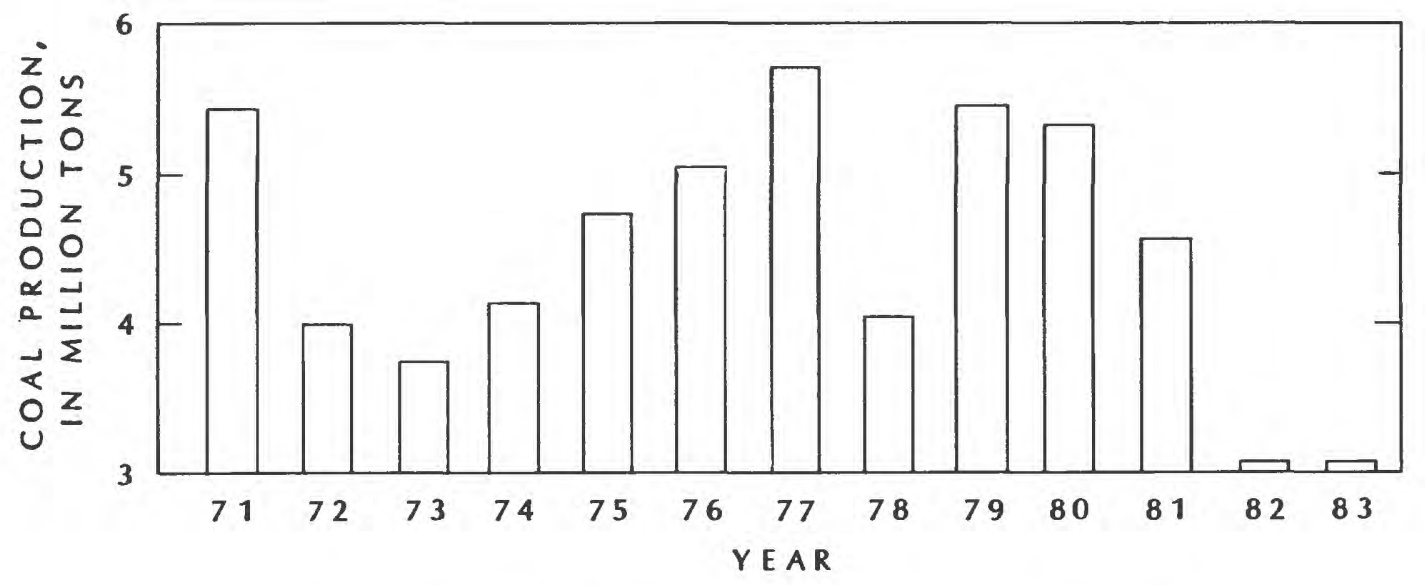

Figure 5.--July to June coal production in the 15county study area from 1971 through 1983.

\section{Surface Drainage}

Principal sub-basins and drainage networks of the study area are shown on figure 6. Drainage basins for all streams in the study area except the Tennessee and Clinch Rivers are contained within the area. The Clinch River enters the study area at Norris Dam and drains an area of 2,912 $\mathrm{mi}^{2}$ at that point. The Tennessee River enters the study area at Fort Loudoun Dam and drains an area of $12,197 \mathrm{mi}^{2}$ at that point.
Average discharge of sub-basin streams in the study area is approximately $2\left(\mathrm{ft}^{3} / \mathrm{s}\right) / \mathrm{mi}^{2}$. However, during dry months the minimum monthly flows per square mile are much lower for streams on the Cumberland Plateau than for streams in the Ridge and Valley due to differences in underlying geology. Average discharge of long-term gaging stations on the main-channel systems of the study area are given in table 2. Flow duration information for the four dam sites in the study area are presented in table 3.

Table 2.--Average discharge of main-channel stations at and above Watts Bar Dam

\begin{tabular}{cccc}
\hline Station & Period of record & $\begin{array}{c}\text { Average discharge } \\
\left(\mathrm{ft}^{3} / \mathrm{s}\right)\end{array}$ & $\left.\left(\mathrm{ft}^{3} / \mathrm{s}\right) / \mathrm{mi}^{2}\right)$ \\
\hline $\begin{array}{c}\text { Clinch River at } \\
\text { Melton Hill Dam. }\end{array}$ & $\begin{array}{c}1936-64, \\
1967-68, \\
1978-82\end{array}$ & 4,650 & 1.4 \\
$\begin{array}{c}1928-82 \\
\text { Emory River } \\
\text { at Oakdale. }\end{array}$ & 1,460 & 1.9 \\
$\begin{array}{c}\text { Tennessee River } \\
\text { at Watts Bar Dam. }\end{array}$ & $\begin{array}{l}1935-39, \\
1975-82\end{array}$ & 28,700 & 1.7 \\
\hline
\end{tabular}




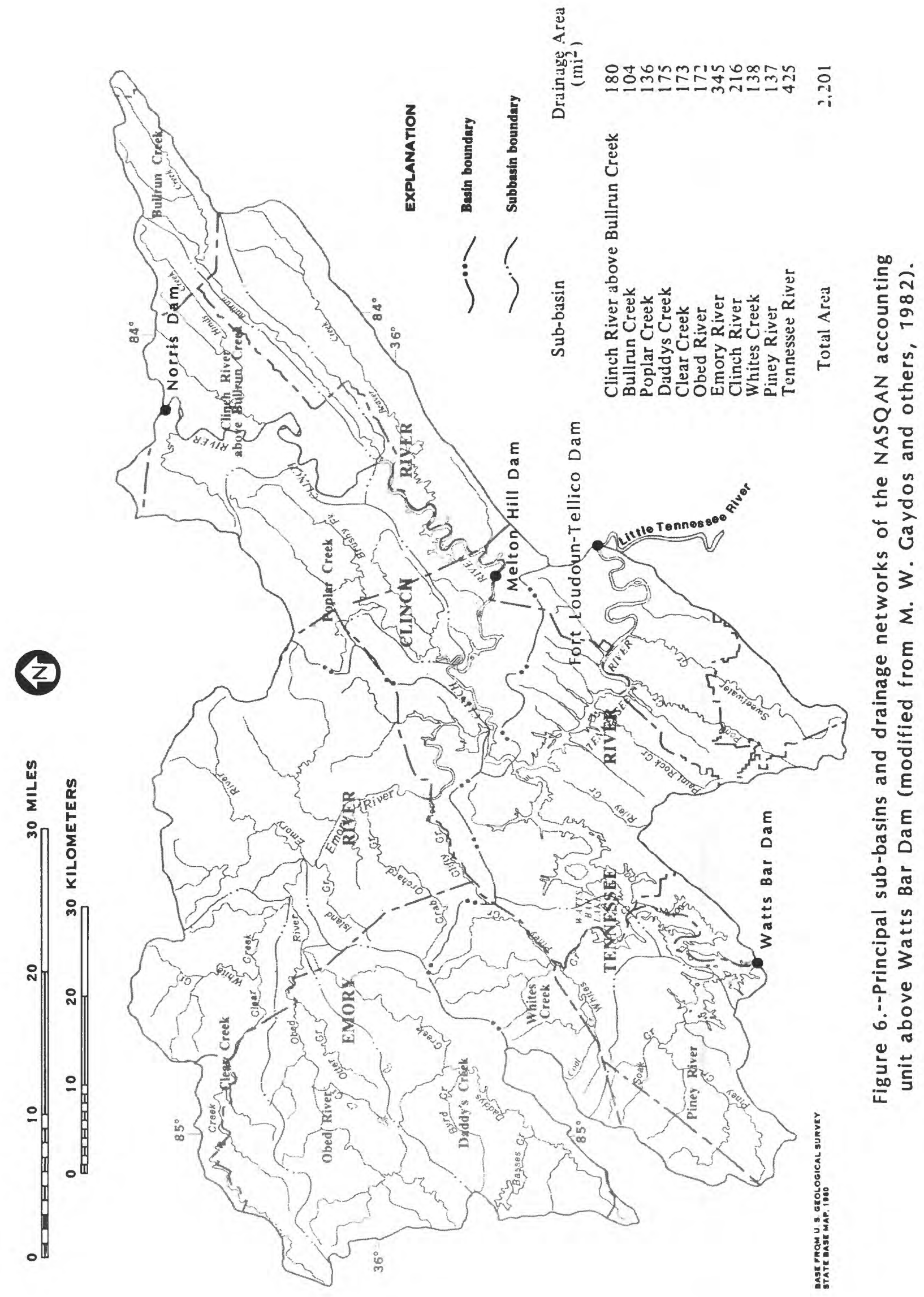


Table 3.--Flow duration of releases from Tennessee River and Clinch River Dams

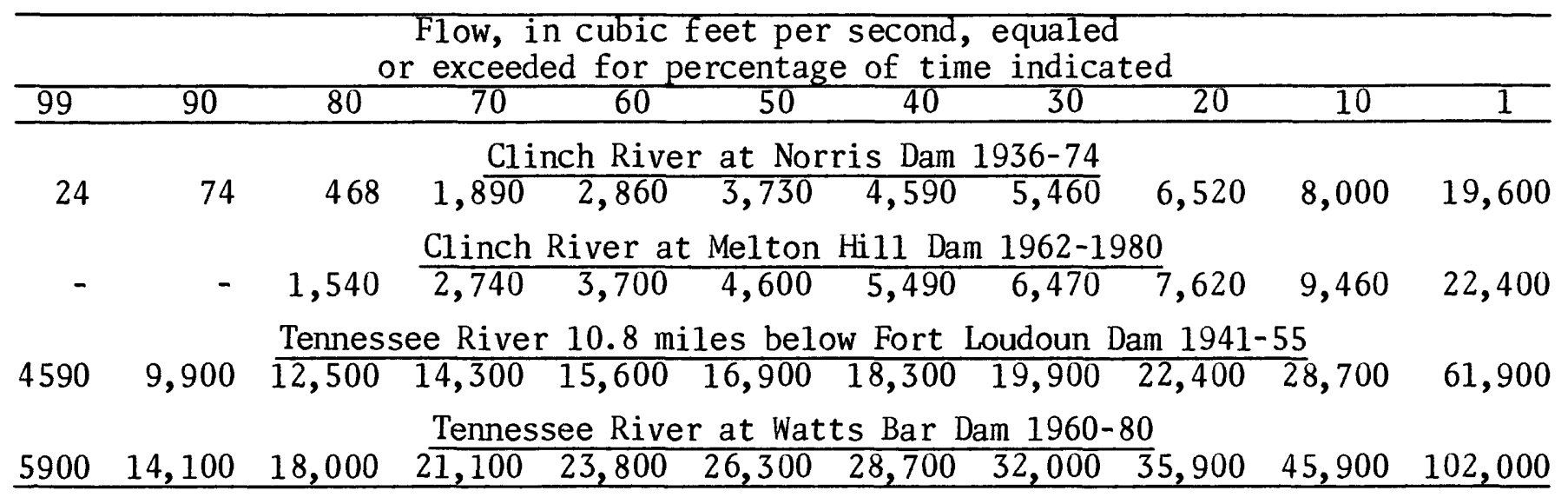

\section{Hydrologic Modifications}

Many farm ponds and small recreation lakes are scattered throughout the study area. In regions where strip-mining occurs, temporary settling ponds were constructed at many of the mine sites.

Upstream from Watts Bar Dam, the Tennessee River is regulated by several dams. These dams were placed into operation between 1936 and 1963. Release patterns for these dams vary daily and seasonally with different uses. The impoundments are used for flood control, power generation, and recreation. A typical pattern of flow releases from Melton Hill and Watts Bar Reservoirs is shown in figure 7.

Watts Bar Dam, at the outlet of the study basin (fig. 6), is a concrete dam with earth embankments. Storage began December 12, 1941. Total level pool capacity at an elevation of 745.00 feet, top of the gates, is 51.2 billion $\mathrm{ft}^{3}$.

Fort Loudoun-Tellico Dam is just upstream from the study area (fig. 6). Closure of Fort Loudoun Dam was made August 2, 1943. Closure of the Tellico Dam was made November 29, 1979. Maximum combined level-pool capacity at an elevation of 815.00 feet, top of the gates, is 56.1 billion $\mathrm{ft}^{3}$. The Tellico-Fort Loudoun canal, which connects Tellico and Fort Loudoun Lakes, was opened January 19, 1980. The spillway gates of Tellico Dam were closed February 7, 1980, diverting all flow from the Little Tennessee River.
Since that date the $t$ wo reservoirs have been operated as one. Prior to November 1979, all streamflow in the Little Tennessee River was discharged into the Watts Bar Lake below Fort Loudoun Dam.

Clinch River flow is regulated by Norris Dam just upstream of the study area and by Melton Hill Dam within the area (fig. 6). Closure of Norris Dam occurred on March 4, 1936, and the total capacity at an elevation of $1,034.11$ feet, top of the gates, is 111 billion $\mathrm{ft}^{3}$. Melton Hill Dam was closed May 1, 1963, and the total capacity at an elevation of 796 feet, top of the gates, is 5.5 billion $\mathrm{ft}^{3}$.

The system of dams and reservoirs on the Clinch and Tennessee Rivers has resulted in backwater along much of the main-channel reaches of the study area. Backwater from Melton Hill Dam at normal maximum reservoir level extends about 44 miles upstream. Backwater from Watts Bar Dam at normal maximum reservoir level extends upstream along the Tennessee River to Fort Loudoun Dam, upstream along the Clinch River to Melton Hill Dam, and to about 13.5 miles above the mouth of the Emory River.

Locations of wastewater discharge sites in the study area as compiled by the Tennessee Department of Public Health (1978) are shown in figure 8. The degree of treatment that the wastewater receives prior to discharge at these sites has not been compiled. 


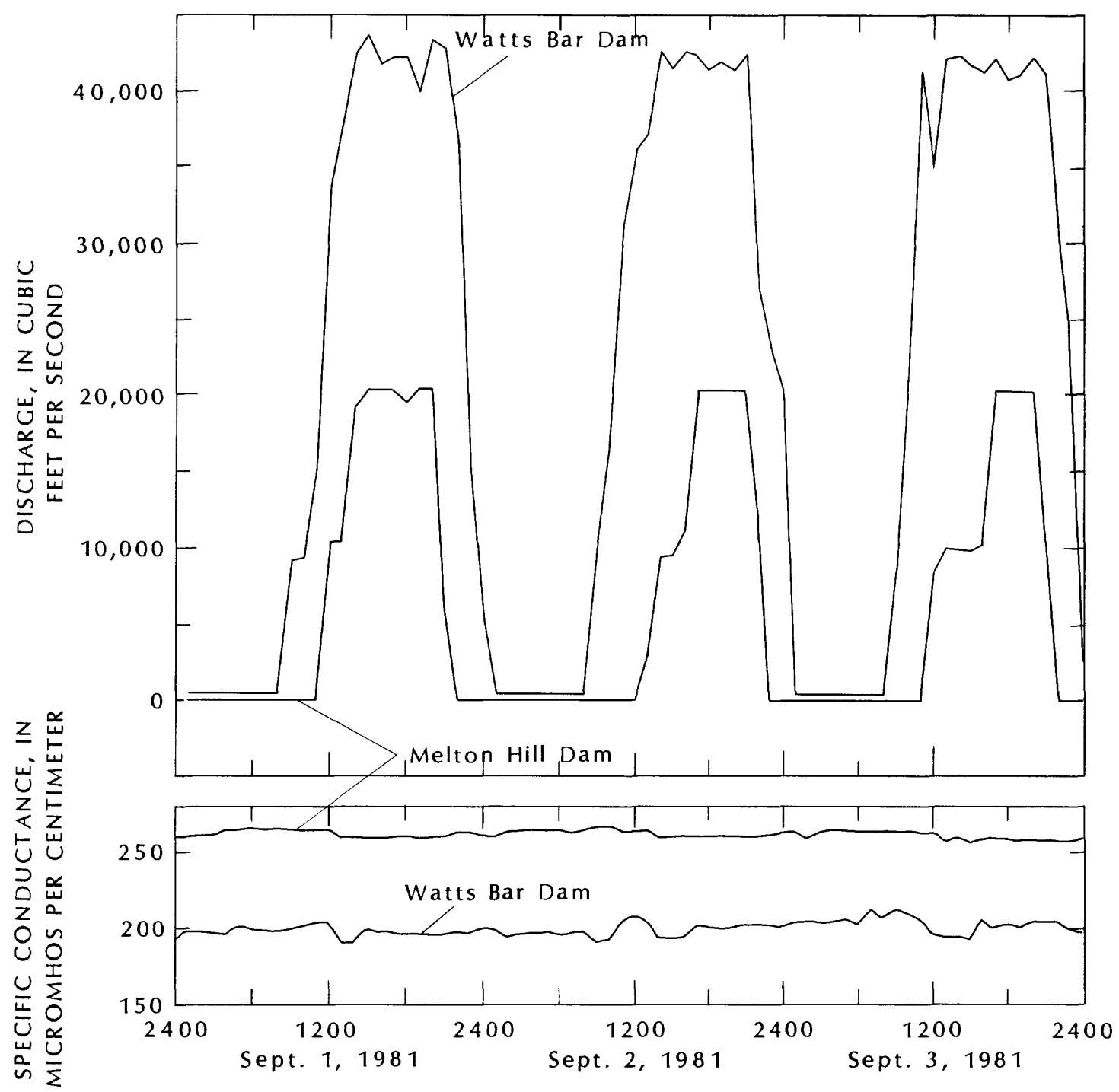

Figure 7.--Discharge and specific conductance of releases from Melton Hill Dam and Watts Bar Dam on September 1-3, 1981. 


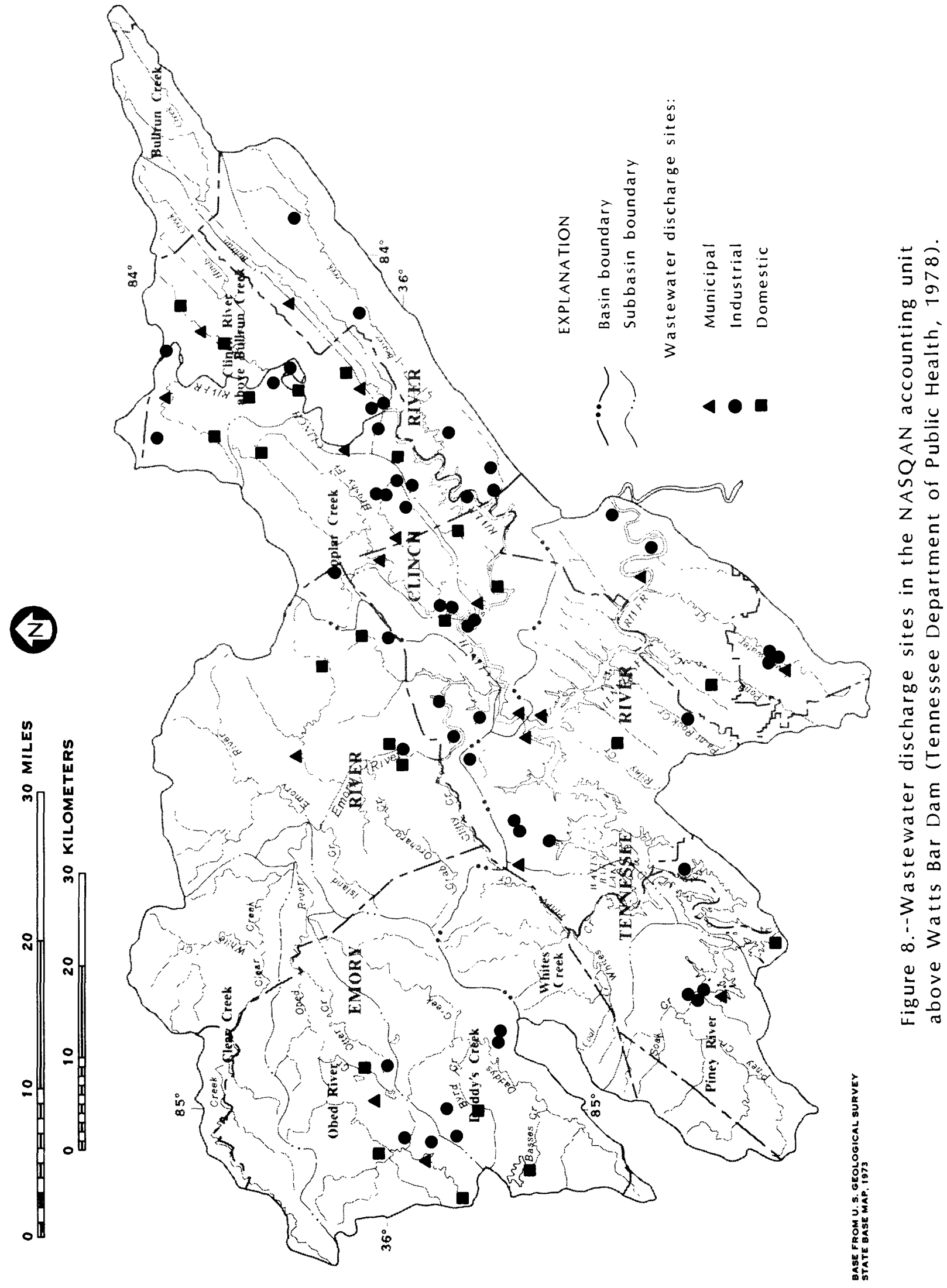




\section{QUALITY OF WATER DATA}

\section{Data Sources}

Most data collected by State and Federal agencies other than the U.S. Geological Survey and used in this report were obtained from STORET, the U.S. Environmental Protection Agency's computer file. The station locations and principal data-collection agency for each station are listed in table 4 and shown on figure 9.

\section{NASQAN Data}

NASQAN stations are operated in the study area on the Clinch River at mile 23.1 (below Melton Hill Dam), and on the Tennessee River at mile 529.9 (below Watts Bar Dam), and are referred to as "Melton Hill" and "Watts Bar" in this report. Continuous observations (hourly) of water temperature and specific conductance were obtained at Watts Bar from February 1976 to September 1981. Continuous observations (hourly) of water temperature and specific conductance were begun at Melton Hill in March 1981 and are currently being collected. Hourly discharge record for both stations is maintained by the Tennessee Valley Authority.

The NASQAN stations are sampled at relatively uniform time intervals, without consideration of streamflow. This temporal sampling scheme was designed to obtain water-quality data representative of what would be expected in a stream on an average day. In a natural stream system, this sampling pattern might be expected to reflect the full range of flow variability at the station. However, the NASQAN stations in the study area are not located on natural, uncontrolled stream systems.

Instantaneous flows at the time of sample collection at the NASQAN stations were compared to the daily mean flow duration tables for those stations (table 3). At Melton Hill, approximately 71 percent of the samples were collected during the upper 30 percent of the duration table, and approximately 16 percent were collected during the lower 30 percent of the duration table. At Watts Bar, approximately 71 percent of the samples were collected during the upper 30 percent of the duration table, and approximately 11 percent were collected during the lower 30 percent of the flow-duration table. These comparisons show the streamflow data obtained at the time of sample collection below Melton Hill Dam and Watts Bar Dam are not randomly distributed.

Duration statistics for daily specific-conductance values obtained at the two NASQAN stations are presented in table 5. A comparison was made of instantaneous specific conductance obtained at the time of sample collection to the parts of the daily specific-conductance duration table to which the values coincided. It was expected that by random sampling approximately 25 percent of the instantaneous observations of specific conductance should fall in the range of daily specific-conductance values equaled or exceeded 25 percent of the time, and approximately 25 percent of the instantaneous values should fall below the daily specific-conductance value equaled or exceeded 75 percent of the time. At Melton Hill, approximately 11 percent of the instantaneous specific-conductance observations were obtained during the upper 25 percent of the duration table and approximately 71 percent were obtained during the lower 25 percent. However, the duration table of continuous specific conductance for Melton Hill is based on only 2 years of record. At Watts Bar, which has 6 years of data, approximately 22 percent of the instantaneous conductance observations were obtained during the upper 25 percent of the duration table, and approximately 32 percent were obtained during the lower 25 percent. The specific-conductance duration table comparisons for Watts Bar indicates that the relatively uniform time interval sampling scheme of the NASQAN program was effective in obtaining randomly distributed samples.

Discharge relations to water quality could not be well defined. This conclusion is supported by comparisons of specific conductance to discharge using the following procedures:

(1) The relation between instantaneous discharge and specific conductance at the time of sample collection was obtained.

(2) The relation between daily mean discharge and daily mean specific conductance for stations with continuous water-quality monitors was obtained. 
Table 4.--Hydrologic data stations in the study area

[Agency codes: USGS, U.S. Geological Survey; TVA, Tennessee Valley Authority; TN, Tennessee Department of Health and Environment; EPA, U.S. Environmental Protection Agency]

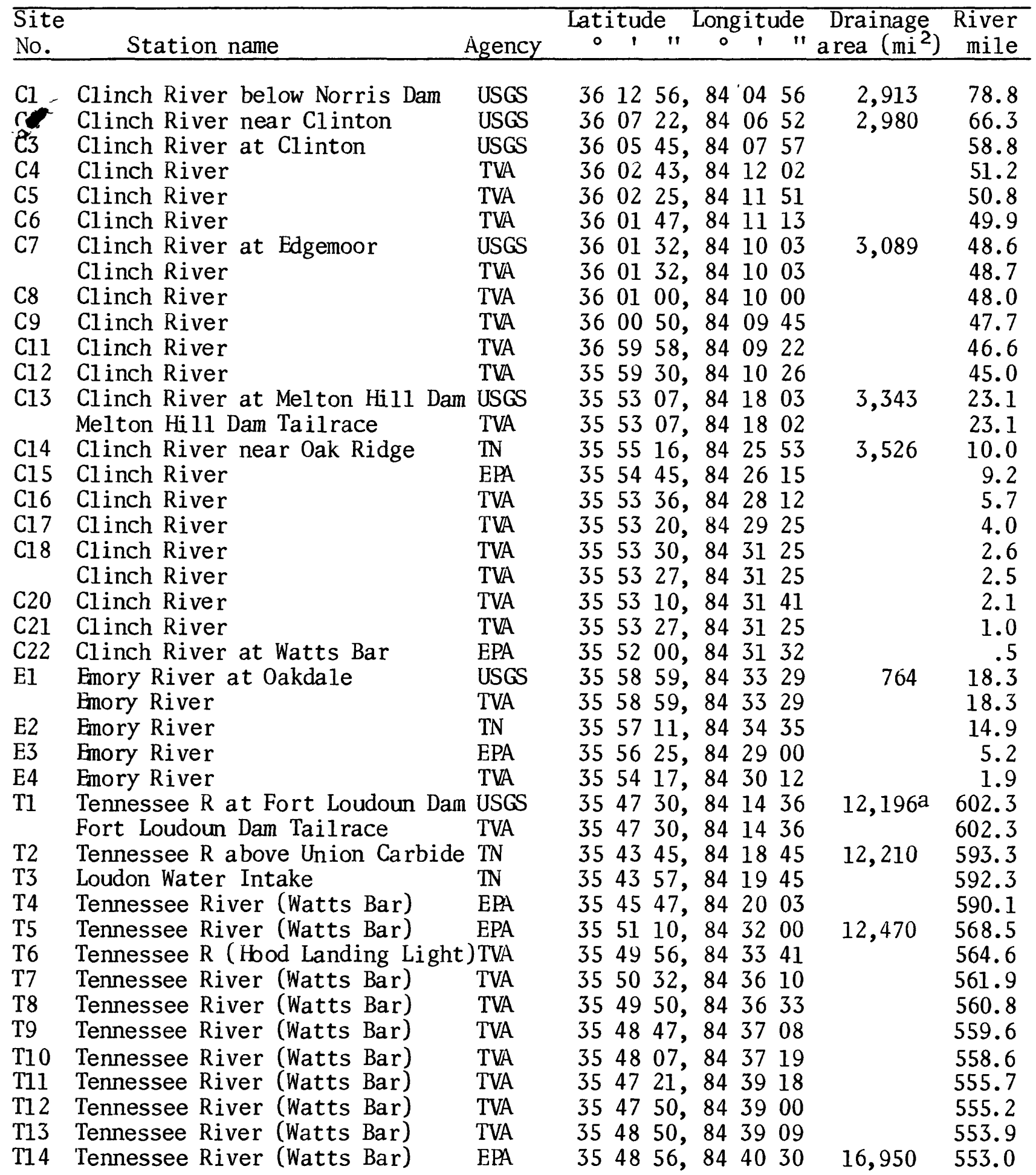


Table 4.--Hydrologic data stations in the study area--Continued

\begin{tabular}{|c|c|c|c|c|c|c|}
\hline $\begin{array}{l}\text { Site } \\
\text { No. }\end{array}$ & Station name & Agency & $\begin{array}{c}\text { Latitude } \\
0\end{array}$ & $\begin{array}{c}\text { Longitude } \\
0, "\end{array}$ & $\begin{array}{l}\text { Drainage } \\
\text { area }\left(\mathrm{mi}^{2}\right)\end{array}$ & $\begin{array}{r}\text { River } \\
\text { mile }\end{array}$ \\
\hline T15 & Tennessee River (Watts Bar) & TVA & 354538 , & $84 \quad 40 \quad 32$ & & 548.5 \\
\hline T16 & Tennessee River (Watts Bar) & EPA & 354056 , & $84 \quad 4452$ & & 538.0 \\
\hline $\mathrm{T} 17$ & Tennessee River (Watts Bar) & TVA & 353900 , & $84 \quad 4700$ & & 532.1 \\
\hline $\mathrm{T} 18$ & Tennessee River (Watts Bar) & EPA & 353721 , & $84 \quad 4700$ & & 530.0 \\
\hline \multirow[t]{2}{*}{ T19 } & Tennessee $\mathrm{R}$ at Watts Bar Dam & USGS & 353713 , & 844700 & 17,310 & 529.9 \\
\hline & Watts Bar Dam Tailrace & TVA & 353712 , & 844659 & & 52 \\
\hline \multirow[t]{2}{*}{$\mathrm{BCl}$} & Bullrun $\mathrm{Cr} \mathrm{nr}$ Halls Crossroads & USGS & 360652 , & 835916 & \multirow[t]{4}{*}{68.5} & 16.3 \\
\hline & Bull run Creek & TVA & 360652 , & 835916 & & \\
\hline $\mathrm{CAl}$ & Clear Creek near Andersonville & USGS & 361258 , & 840300 & & \\
\hline CA2 & Clear Creek at Norris & USGS & 361248 , & $8403 \quad 38$ & & \\
\hline CA3 & Coal Creek at Lake City & USGS & 361314 , & 840927 & \multirow[t]{2}{*}{24.5} & \\
\hline $\mathrm{CB} 1$ & Beaver Creek & TN & 360331 , & $83 \quad 5823$ & & \\
\hline $\mathrm{CCl}$ & White Creek at Twin Bridges & USGS & 361040 & $84 \quad 4801$ & 38.4 & \\
\hline $\mathrm{CC} 2$ & Clear Creek near Lancing & USGS & 360718 , & $8444 \quad 46$ & 153 & \\
\hline DC1 & Daddys Creek near Hebbertsburg & USGS & 355953 , & $84 \quad 49 \quad 24$ & 139 & \\
\hline ER1 & Rock Creek near Gobey & USGS & 360802 , & 843731 & 31.2 & \\
\hline ER2 & Emory River near Wartburg & USGS & 360646 , & $84 \quad 3654$ & 83.2 & \\
\hline ER3 & Island Creek near Catoosa & USGS & 360310 & $84 \quad 40 \quad 01$ & 18.4 & \\
\hline ER4 & Crooked Fork near Wartburg & USGS & 360505 , & 843318 & \multirow[t]{3}{*}{50.3} & \\
\hline \multirow[t]{2}{*}{ ER5 } & Crooked Fork at Wartburg & USGS & 360456 , & $8434 \quad 35$ & & \\
\hline & Crooked Fork Creek $4.22^{\circ}$ & TVA & 360455 , & 843435 & & \\
\hline ER6 & Crab Orchard near Deermont & USGS & 360040 , & 843644 & \multirow[t]{3}{*}{33.7} & \\
\hline ER7 & Emory River at Mahan Village & USGS & 361039 , & 842828 & & \\
\hline ER8 & Emory River 34.52 & TVA & 360647 , & 843655 & & \\
\hline ER9 & Emory River at Gobey & USGS & 360858 , & 843550 & \multirow[t]{5}{*}{43.3} & \\
\hline ER10 & Flat Fork near Petros & USGS & 360735 , & 843011 & & \\
\hline \multirow[t]{2}{*}{ OR1 } & Obed River near Crossville & USGS & 355827 & $8502 \quad 55$ & & \\
\hline & Obed River NW of Crossvile & TVA & 355828 , & 850255 & & \\
\hline OR2 & Obed River at Adams Bridge & USGS & 360342 , & 845742 & & \\
\hline OR3 & Obed River near Lancing & USGS & 360453 , & $84 \quad 40 \quad 15$ & 518 & 1.5 \\
\hline $\mathrm{PCl}$ & East Fork Poplar Creek & USGS & 355758 , & 842130 & 19.5 & 3.3 \\
\hline $\mathrm{PC} 2$ & Poplar Creek at Baily Road & USGS & 360157 , & 841816 & 30.3 & \\
\hline PC3 & Poplar Creek near Oak Ridge & USGS & 355955 , & 842023 & 82.5 & 13.8 \\
\hline \multirow[t]{2}{*}{ PR1 } & Piney River at Spring City & USGS & 354159 , & $84 \quad 51 \quad 17$ & \multirow[t]{2}{*}{95.9} & \\
\hline & Piney River 6.8 & TN & 354228 & $84 \quad 5131$ & & \\
\hline \multirow[t]{2}{*}{ PR2 } & Piney River above Spring City & USGS & 354302 , & 845308 & \multirow[t]{4}{*}{62.3} & \\
\hline & Piney River 9.0 & TN & 354256 , & 845251 & & \\
\hline PR3 & Piney River 12.6 & TN & 354128 , & $8454 \quad 40$ & & \\
\hline PR4 & Piney River 20.9 & TN & 353720 , & 845752 & & \\
\hline TR1 & Pond Creek near Adolphus & USGS & 354220 , & 842735 & \multirow[t]{2}{*}{30.8} & \\
\hline TR2 & Caney Creek 0.7 & TVA & 355119 , & 843554 & & \\
\hline WCl & Whites Creek at Bakers Bridge & USGS & 354750 , & 844843 & 33.8 & \\
\hline WC2 & Piney Creek near Westel & USGS & 355114 , & $\begin{array}{lll}84 & 44 & 17\end{array}$ & 19.0 & \\
\hline WC3 & Fal1 Creek near Ozone & USGS & 355016 & $\begin{array}{lll}84 & 47 & 56\end{array}$ & 21.1 & \\
\hline
\end{tabular}

aPrior to November, 1979, drainage area did not include that of the Little Tennessee River and was $9,550 \mathrm{mi}^{2}$. 


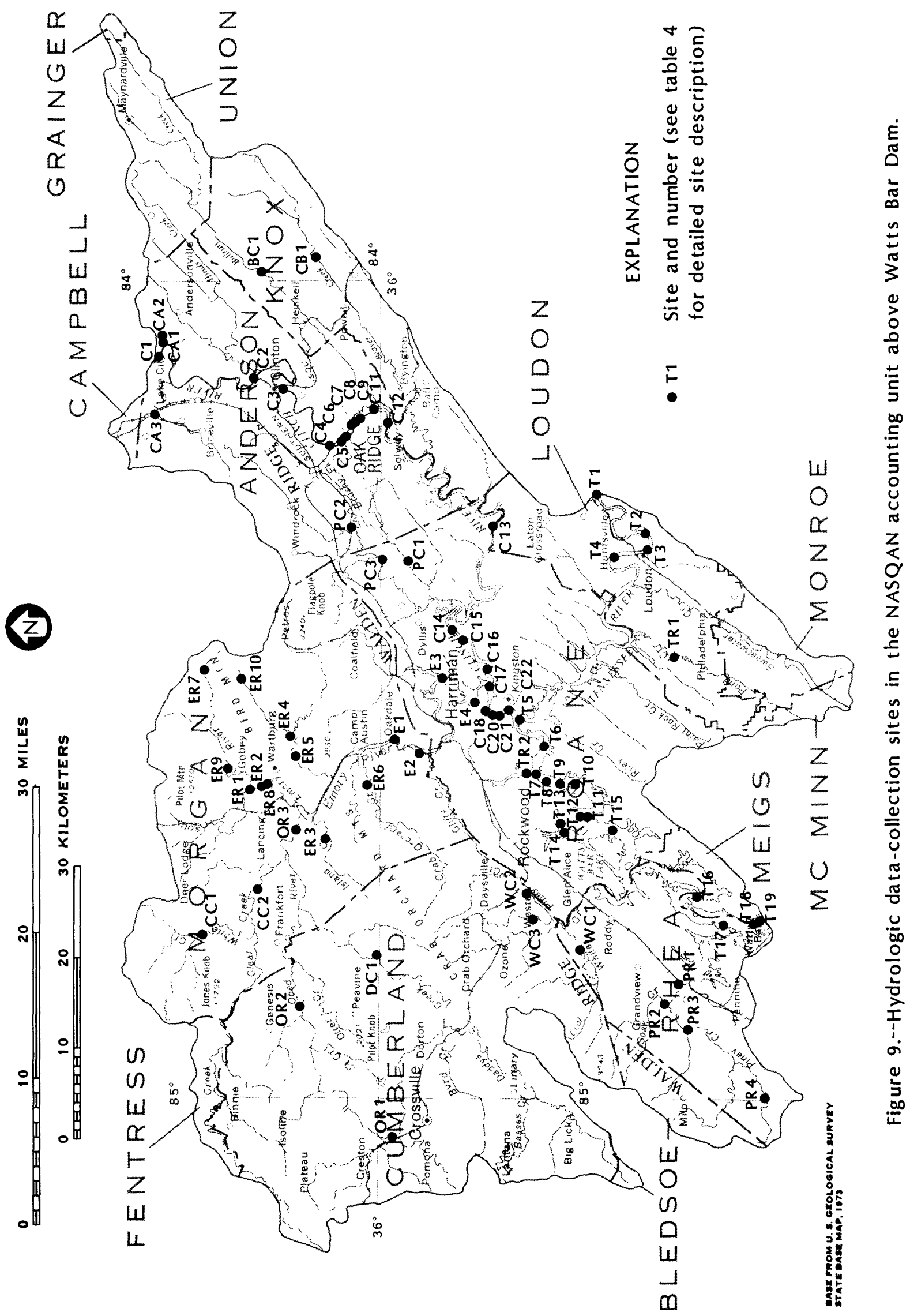


Table 5. - -Daily specific conductance, in microsiemens per centimeter at $25^{\circ} \mathrm{C}$, that was equaled or exceeded for the indicated percentage of time at the Melton Hill and Watts Bar NASQAN stations

\begin{tabular}{|c|c|c|c|c|c|c|c|c|c|c|c|}
\hline \multirow{2}{*}{$\begin{array}{l}\text { Site } \\
\text { No. }\end{array}$} & \multicolumn{3}{|c|}{ No. of days } & \multicolumn{8}{|c|}{ Percentage of time } \\
\hline & Station of & record & $\overline{1}$ & 5 & 10 & 25 & 50 & 75 & 90 & $\overline{95}$ & $\overline{99}$ \\
\hline 13 & $\begin{array}{l}\text { Melton Hi } 11 \\
(1981-82)\end{array}$ & 547 & 281 & 272 & 269 & 262 & 254 & 240 & 231 & 219 & 199 \\
\hline T19 & $\begin{array}{l}\text { Watts Bar } \\
(1976-81)\end{array}$ & 1792 & 208 & 200 & 191 & 177 & 161 & 150 & 137 & 130 & 110 \\
\hline
\end{tabular}

None of the regression results are considered significant. For example, the best model for comparison of mean daily discharge to mean daily specific conductance accounted for only 7 percent of the relation variation.

\section{TREND ANALYSIS TECHNIQUES}

The Seasonal Kendall test is a nonparametric test for trend applicable to data influenced by seasonal variations. By use of this test the effects of seasonal variations of the data is reduced by comparing only observations from the same time interval of the year.

The null hypothesis for the Seasonal Kendall test is that the random variable is independent and identically distributed. The resultant statistic (tau) has a value between -1 and +1 . Negative values indicate decreasing trends, positive values indicate increasing trends. If no trend exists in the data, tau approaches zero. A significance probability ( $p$-level) of the trend is computed that indicates the probability of erroneously rejecting the null hypothesis (that no trend exists). The Seasonal Kendall test is specifically designed to provide a single summary statistic for the entire record and will not indicate when there are trends in opposing directions.

The Seasonal Kendall Slope Estimator is an estimate of the magnitude of the trend defined by the Seasonal Kendall test. For this estimate the data value difference divided by the period of time separating the data values is computed. The median of these differences (expressed as slopes) is defined to be the change per year due to the trend. By using the median of these individual slope values, the trend estimate is resistant to the effect of extreme values in the data. The estimate is also unaffected by seasonal variations in the data because the slopes are always computed between values that are multiples of 12 months apart (Hirsch and others, 1982).

In many streams, some water-quality parameters are related to stream discharge. For example, much of the constituent loadings may be from point sources and any decrease in flow would tend to be accompanied by increases in concentration. Another example is that of rainfall over an urban area that results in washoff of accumulated pollutants into receiving waters thus increasing concentrations of some water-quality constituents. Conversley, increased stream discharge may result in lower concentrations because of dilution.

Compensation for the effects of discharge is necessary in order to identify trends in waterquality constituents caused by some process (source) change. To minimize the effects of discharge, a time series of flow-adjusted concentrations is developed and this time series is then tested for trend. For this report, regression equations were developed for each water-quality parameter for each data collection site. A conditional expected concentration was estimated for parameters having a well-defined relation to discharge. The Seasonal Kendall trend test procedures were applied to the actual concentrations minus the estimated conditional expected concentration (residual analysis). 
Some common models used for flow adjustment include the following (Crawford and others, 1983):
(1) $\mathrm{C}=\mathrm{a}+\mathrm{bQ}$
(2) $\quad C=a+b \ln (Q)$
(3) $\quad C=a+b(1 / 1+B Q)$
(4) $C=a+b(1 / Q)$
(5) $\quad C=a+b_{1} Q_{+}+b_{2} Q^{2}$
(6) $\ln C=a+b \ln Q$
(7) $\ln C=a+b \ln Q+b_{2}(\ln Q)^{2}$

where

$\mathrm{C}$ is the expected concentration,

$\mathrm{Q}$ is the discharge at the time of sampling, and

$\mathrm{B}$ is a constant typically in the range $10^{-3}$ $\mathrm{q}^{-1} \leq \mathrm{B} \leq 10^{2} \mathrm{q}^{-1}$

where $\mathrm{q}$ is the mean discharge.

The model selected for flow adjustment is generally the one that explains the greatest relation variance. If the probability of rejecting the null hypothesis that $b=0$ for the relation is high (greater than 0.10 for this study), then no flow adjustment is recommended. Note that for $C$ models the residuals have the dimensions of $\mathrm{C}$, but for In $\mathrm{C}$ models the residuals are dimensionless.

Results of Seasonal Kendall tests on discharge and specific-conductance data for continuous-record stations in the study area are shown in table 6. Discharge at all continuousrecord stations in the study area shows a significant decreasing trend during the 1972-82 water years. It is important to note that because of regulation, discharge versus water-quality relations for the Clinch River and Tennessee River stations in the study area are not well defined and no flow adjustment was possible. Therefore, the water-quality trends indicated in this report for the Clinch River and Tennessee River stations may only be reflective of the discharge trend rather than changes in the processes that affect the introduction and fate of a given constituent in the river.

\section{WATER-QUALITY SUMMARIES AND TREND TEST RESULTS}

Water-quality data obtained in the study area sub-basins are summarized in tables 7 and 8 .

Table 6.--Results of trend tests of discharge and specific conductance obtained at daily record stations at or above Watts Bar Dam during the 1972-82 water years

[Nvals, the number of seasonal values constructed. Seasons were based on weekly median values. Units are the reporting units, cubic feet per second or microsiemens per centimeter per year]

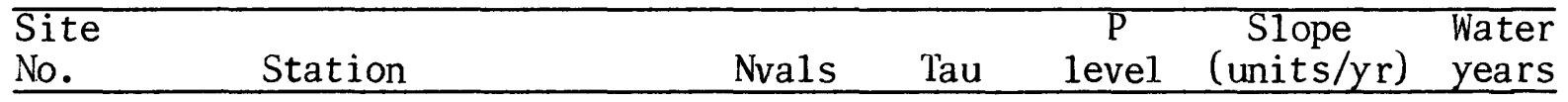

\section{$\underline{\text { Discharge (cubic feet per second) }}$}

T19 Tennessee R. at Watts Bar Dam

C13 Clinch R. at Melton Hi11 Dam

E1 Emory River at Oakdale

$\mathrm{BCl}$ Bullrun Cr. nr Halls Crossroads 572

PC3 Poplar Cr. near Oak Ridge

PCl E. Fork Poplar Creek

OR3 Obed River near Lancing
416

208

572

572

572

499

$$
\begin{array}{r}
-0.197 \\
-. .349 \\
-.123 \\
-.174 \\
-.193 \\
-.195 \\
-.149
\end{array}
$$

0
0
0
0
0
0
0

$-860$

$-730$

$-15$

$-1.0$

$-2.1$

$-.67$

$-11$
75-82

79- 82

72-82

72-82

72-82

72-82

73-82

Specific Conductance (microsiemens per centimeter at $25^{\circ} \mathrm{C}$ )

\begin{tabular}{llrrrrr} 
T19 Tennessee R. at Watts Bar Dam & 263 & .163 & 0.004 & 2.4 & $76-82$ \\
C13 C1inch R. at Melton Hi 11 Dan & 80 & -.679 & .001 & -16 & $81-82$ \\
\hline
\end{tabular}


Table 7.--Median value of selected water-quality in the sub-basins of the study

\begin{tabular}{|c|c|c|c|c|c|c|c|c|}
\hline \multirow[b]{2}{*}{$\begin{array}{l}\text { Site } \\
\text { No. }\end{array}$} & \multicolumn{2}{|c|}{$\begin{array}{l}\text { Specific } \\
\text { conductance }\end{array}$} & \multicolumn{2}{|c|}{$\mathrm{pH}$} & \multicolumn{2}{|c|}{$\begin{array}{l}\text { Total nitrite plus } \\
\text { nitrate nitrogen }\end{array}$} & \multicolumn{2}{|c|}{$\begin{array}{l}\text { Suspended } \\
\text { sediment }\end{array}$} \\
\hline & $\begin{array}{l}\text { No. of } \\
\text { samples }\end{array}$ & $\begin{array}{l}\text { Median } \\
\mu \mathrm{S} / \mathrm{cm}\end{array}$ & $\begin{array}{l}\text { No. of } \\
\text { samples }\end{array}$ & Median & $\begin{array}{l}\text { No. of } \\
\text { samples }\end{array}$ & $\begin{array}{l}\text { Median } \\
\text { (mg/L) }\end{array}$ & $\begin{array}{l}\text { No. of } \\
\text { samples }\end{array}$ & $\begin{array}{l}\text { Median } \\
(\mathrm{mg} / \mathrm{L})\end{array}$ \\
\hline $\mathrm{BCl}$ & 68 & 309 & 15 & 7.7 & 15 & 0.30 & & \\
\hline CA1 & 7 & 220 & 7 & 7.5 & & & & \\
\hline $\mathrm{CA} 2$ & 8 & 225 & 8 & 7.6 & & & & \\
\hline $\mathrm{CA} 3$ & 8 & 348 & 9 & 7.8 & 1 & .16 & 8 & 20 \\
\hline CB1 & 61 & 289 & & & 90 & .23 & & \\
\hline $\mathrm{CCl}$ & 4 & 27 & 4 & 6.6 & 1 & .06 & 3 & 1 \\
\hline $\mathrm{CC} 2$ & 11 & 48 & 11 & 7.0 & 1 & .04 & 10 & 4 \\
\hline $\mathrm{DCl}$ & 8 & 49 & 8 & 7.2 & 1 & .44 & 7 & 38 \\
\hline $\mathrm{ER} 1$ & 6 & 54 & 6 & 7.0 & 1 & .16 & 5 & 55 \\
\hline ER2 & 12 & 54 & 13 & 6.8 & 12 & .08 & & \\
\hline ER3 & 6 & 30 & 6 & 6.6 & 1 & .08 & 4 & 5 \\
\hline ER4 & 6 & 218 & 6 & 7.0 & & & 4 & 8 \\
\hline ER5 & 16 & 165 & 17 & 7.1 & 15 & .25 & & \\
\hline ER6 & 6 & 98 & 6 & 5.4 & 1 & .08 & 5 & 7 \\
\hline ER7 & 2 & 200 & 2 & 7.3 & & & & \\
\hline ER8 & 16 & 60 & 17 & 6.9 & 16 & .08 & & \\
\hline ER9 & 9 & 105 & 9 & 6.9 & 1 & .04 & 8 & 7 \\
\hline ER10 & 1 & 34 & 1 & 8.0 & & & & \\
\hline OR1 & 17 & 100 & $1 \overline{8}$ & 6.9 & 15 & .61 & & \\
\hline OR2 & 11 & 46 & 11 & 5.8 & 11 & .25 & & \\
\hline OR3 & 30 & 60 & & & & & & \\
\hline $\mathrm{PCl}$ & 43 & 340 & & & & & & \\
\hline PC2 & 6 & 198 & 6 & 7.5 & 1 & .11 & 5 & 20 \\
\hline PC3 & 59 & 240 & 23 & 7.5 & 2 & .53 & 23 & 31 \\
\hline PR1 & 6 & 54 & 7 & 7.0 & 2 & .12 & 5 & 3 \\
\hline PR2 & 6 & 44 & 7 & 6.6 & 2 & .06 & 5 & 14 \\
\hline PR3 & & & 1 & 6.3 & 1 & .01 & & \\
\hline PR4 & & & 1 & 5.5 & 1 & .11 & & \\
\hline TR1 & 8 & 272 & & & & & & \\
\hline TR2 & 6 & 191 & 6 & 7.8 & 6 & .30 & & \\
\hline WCl & 9 & 29 & 9 & 6.9 & 1 & .03 & 8 & 3 \\
\hline WC2 & 6 & 50 & 6 & 6.9 & 1 & .12 & 5 & 8 \\
\hline WC3 & 6 & 74 & 6 & 7.3 & 1 & .06 & 5 & 14 \\
\hline
\end{tabular}


parameters and number of samples obtained at stations area during the 1972-82 water years

\begin{tabular}{|c|c|c|c|c|c|}
\hline \multirow{2}{*}{\multicolumn{2}{|c|}{ 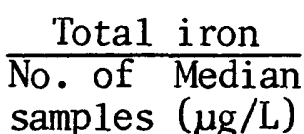 }} & \multirow{2}{*}{$\begin{array}{l}\text { Dissolved } \\
\text { No. of } \\
\text { samples }\end{array}$} & \multirow{2}{*}{$\begin{array}{l}\frac{\text { sulfate }}{\text { Median }} \\
(\mathrm{mg} / \mathrm{L})\end{array}$} & \multicolumn{2}{|c|}{ Dissolved solids } \\
\hline & & & & $\begin{array}{l}\text { No. of } \\
\text { samples }\end{array}$ & $\begin{array}{l}\text { Median } \\
(\mathrm{mg} / \mathrm{L})\end{array}$ \\
\hline 15 & 440 & 15 & 10 & 12 & 180 \\
\hline 7 & 40 & 7 & 2.9 & 7 & 127 \\
\hline 8 & 35 & 8 & 3.0 & 8 & 124 \\
\hline 9 & 510 & 9 & 84 & 4 & 258 \\
\hline 91 & 1300 & 91 & 12 & & \\
\hline 4 & 390 & 4 & 4.0 & 1 & 43 \\
\hline 9 & 200 & 9 & 7.3 & 5 & 33 \\
\hline 8 & 755 & 8 & 5.8 & 1 & 79 \\
\hline 6 & 880 & 6 & 7.4 & 1 & 88 \\
\hline 12 & 525 & 12 & 15 & 12 & 40 \\
\hline 6 & 240 & 6 & 7.7 & 1 & 26 \\
\hline 6 & 560 & 6 & 72 & 1 & 259 \\
\hline 16 & 410 & 16 & 49 & 16 & 110 \\
\hline 6 & 480 & 6 & 34 & 1 & 337 \\
\hline & & 2 & 72 & 2 & 101 \\
\hline 16 & 560 & 16 & 16 & 16 & 45 \\
\hline 8 & 470 & 9 & 30 & 4 & 68 \\
\hline & & 1 & 7.6 & 1 & 46 \\
\hline 15 & 360 & 17 & 10 & 12 & 55 \\
\hline 11 & 350 & 10 & 7.0 & 11 & 30 \\
\hline 6 & 565 & 6 & 48 & 1 & 226 \\
\hline 21 & 570 & 22 & 39 & 23 & 146 \\
\hline 7 & 150 & 6 & 7.8 & 1 & 56 \\
\hline 7 & 250 & 6 & 7.2 & 1 & 39 \\
\hline 1 & 180 & & & & \\
\hline 1 & 400 & & & & \\
\hline 3 & 465 & & & & \\
\hline 9 & 200 & 9 & 5.2 & 4 & 20 \\
\hline 6 & 215 & 6 & 5.7 & 1 & 64 \\
\hline 6 & 390 & 6 & 8.2 & 1 & 85 \\
\hline
\end{tabular}


Table 8. --Summaries of selected constituent values obtained in sub-basins above Watts Bar Dam during the 1972-82 water years

\begin{tabular}{|c|c|c|c|c|c|c|}
\hline Sub-basin & $\begin{array}{l}\text { Number of } \\
\text { samples }\end{array}$ & Minimum & Maximum & Median & Mean & $\begin{array}{l}\text { Standard } \\
\text { deviation }\end{array}$ \\
\hline \multicolumn{7}{|c|}{ Dissolved solids, residue at $180^{\circ} \mathrm{C}(\mathrm{mg} / \mathrm{L})$} \\
\hline $\begin{array}{l}\mathrm{Cl} \text { inch River } \\
\text { above Bullrun } \mathrm{Cr} \text {. }\end{array}$ & 19 & 85 & 270 & 131 & 146 & 58 \\
\hline Bullrun Creek & 12 & 160 & 210 & 180 & 182 & 18 \\
\hline Poplar Creek & 24 & 69 & 226 & 157 & 154 & 48 \\
\hline Daddys Creek & 1 & & 79 & & & \\
\hline Clear Creek & 6 & 25 & 46 & 34 & 36 & 7.7 \\
\hline Obed River & 23 & 20 & 180 & 40 & 59 & 42 \\
\hline Emory River & 67 & 20 & 337 & 80 & 90 & 67 \\
\hline Whites Creek & 6 & 18 & 85 & 26 & 40 & 28 \\
\hline Piney River & 2 & 39 & 56 & & & \\
\hline \multicolumn{7}{|c|}{ Specific conductance (microsiemens per centimeter at $25^{\circ} \mathrm{C}$} \\
\hline $\begin{array}{l}\text { Clinch River } \\
\text { above Bullrun } \mathrm{Cr} \text {. }\end{array}$ & 23 & 115 & 580 & 230 & 250 & 110 \\
\hline Bullrun Creek & 80 & 17 & 400 & 310 & 291 & 71 \\
\hline Poplar Creek & 108 & 80 & 480 & 268 & 267 & 86 \\
\hline Daddys Creek & 8 & 36 & 130 & 49 & 70 & 39 \\
\hline Clear Creek & 15 & 22 & 67 & 48 & 45 & 15 \\
\hline Obed Rivera & 68 & 36 & 350 & 69 & 98 & 81 \\
\hline Emory River & 92 & 20 & 695 & 108 & 130 & 110 \\
\hline $\begin{array}{l}\text { C1inch River } \\
\text { below Bull run } \mathrm{Cr} \text {. }\end{array}$ & 61 & 4 & 379 & 289 & 282 & 49 \\
\hline Whites Creek & 21 & 26 & 195 & 41 & 61 & 46 \\
\hline Piney River & 12 & 26 & 120 & 46 & 55 & 32 \\
\hline Tennessee River & 14 & 25 & 310 & 222 & 220 & 72 \\
\hline \multicolumn{7}{|c|}{$\mathrm{pH}$ (standard units) } \\
\hline $\begin{array}{l}\text { Clinch River } \\
\text { above Bullrun } \mathrm{Cr} .\end{array}$ & 24 & 6.8 & 8.7 & 7.6 & & \\
\hline Bullrun Creek & 27 & 7.0 & 8.1 & 7.7 & & \\
\hline Poplar Creek & 29 & 5.8 & 8.1 & 7.5 & & \\
\hline Daddys Creek & 8 & 6.6 & 7.8 & 7.2 & & \\
\hline Clear Creek & 15 & 6.1 & 7.5 & 6.9 & & \\
\hline Obed River & 40 & 5.1 & 7.9 & 6.8 & & \\
\hline Fmory River & 96 & 4.0 & 8.3 & 6.9 & & \\
\hline Whites Creek & 21 & 6.3 & 7.9 & 6.9 & & \\
\hline Piney River & 16 & 5.3 & 8.1 & 6.6 & & \\
\hline $\begin{array}{l}\text { Tennessee River } \\
\text { below Fort Loudour }\end{array}$ & 6 & 7.4 & 8.3 & 7.8 & & \\
\hline
\end{tabular}


Table 8. --Summaries of selected constituent values obtained in sub-basins above Watts Bar Dam during the 1972-82 water years--Continued

\begin{tabular}{|c|c|c|c|c|c|c|}
\hline Sub-basin & $\begin{array}{c}\text { Number of } \\
\text { samples }\end{array}$ & Minimum & Maximum & Median & Mean & $\begin{array}{l}\text { Standard } \\
\text { deviation }\end{array}$ \\
\hline \multicolumn{7}{|c|}{ Sulfate, dissolved $\left(\mathrm{mg} / \mathrm{L}\right.$ as $\left.\mathrm{SO}_{4}\right)$} \\
\hline $\begin{array}{l}\mathrm{Cl} \text { inch River } \\
\text { above Bull run } \mathrm{Cr} \text {. }\end{array}$ & 24 & 2.0 & 130 & 3.5 & 31 & 41 \\
\hline Bull run Creek & 27 & 1.0 & 16 & 10 & 9.3 & 4.6 \\
\hline Poplar Creek & 28 & 21 & 88 & 40 & 42 & 17 \\
\hline Daddys Creek & 8 & 5.0 & 8.7 & 5.8 & 6.2 & 1.2 \\
\hline Clear Creek & 13 & 2.9 & 9.8 & 5.7 & 6.1 & 2.2 \\
\hline Obed River & 37 & 5.0 & 32 & 8.0 & 9.8 & 5.0 \\
\hline Fmory River & 92 & 4.8 & 210 & 24 & 49 & 56 \\
\hline $\begin{array}{l}\text { Clinch River } \\
\text { below Bullrun } \mathrm{Cr} \text {. }\end{array}$ & 91 & 3.0 & 43 & 12 & 13 & 6.9 \\
\hline Whites Creek & 21 & 4.1 & 13 & 5.6 & 6.5 & 2.4 \\
\hline Piney River & 12 & 4.8 & 13 & 7.4 & 8.3 & 3.2 \\
\hline \multicolumn{7}{|c|}{ Iron, total recoverable ( $\mu \mathrm{g} / \mathrm{L}$ as $\mathrm{Fe}$ ) } \\
\hline $\begin{array}{l}\text { Clinch River } \\
\text { above Bullrun } \mathrm{Cr} \text {. }\end{array}$ & 41 & 10 & 44,000 & 45 & 2150 & 8900 \\
\hline Bull run Creek & 27 & 130 & 1,600 & 440 & 652 & 450 \\
\hline Popla & 27 & & 12,000 & 570 & 1900 & 3200 \\
\hline Daddys Creek & 8 & 180 & 3,400 & 755 & 1100 & 1100 \\
\hline $\mathrm{Cl}$ & 13 & 50 & 950 & 260 & 308 & 240 \\
\hline bed River & 36 & 150 & 2,000 & 368 & 478 & 410 \\
\hline Emory River & 88 & 80 & 10,000 & 495 & 999 & 1900 \\
\hline $\begin{array}{l}\mathrm{C} 1 \text { inch River } \\
\text { below Bullrun } \mathrm{Cr} \text {. }\end{array}$ & 91 & 150 & 3,900 & 1300 & 1360 & 750 \\
\hline Ihites Creek & 21 & 60 & 3,400 & 200 & 454 & 720 \\
\hline & 16 & 100 & 7,400 & 215 & 9 & 2000 \\
\hline $\begin{array}{l}\text { Tennessee River } \\
\text { below Fort Loudoun }\end{array}$ & 3 & 305 & 670 & 465 & 480 & 180 \\
\hline \multicolumn{7}{|c|}{$\mathrm{Nitrogen}$, total $\mathrm{NO}_{2}+\mathrm{NO}_{3}(\mathrm{mg} / \mathrm{L}$ as $\mathrm{N})$} \\
\hline $\begin{array}{l}\text { Clinch River } \\
\text { above Bull run } \mathrm{Cr} \text {. }\end{array}$ & & & 0.16 & & & \\
\hline Bull run Creek & 27 & 0.01 & .6 & 0.30 & 0.29 & 0.15 \\
\hline & 3 & .1 & & .48 & & .25 \\
\hline Daddys Creek & 1 & & .44 & & & \\
\hline Clea & 2 & .0 & .06 & & & \\
\hline & 36 & .0 & 5.6 & .42 & .95 & 1.3 \\
\hline & 60 & .0 & 5. & & & .94 \\
\hline $\begin{array}{l}\mathrm{Cl} \text { inch River } \\
\text { below Bullrun C }\end{array}$ & 90 & .01 & .87 & .23 & .24 & .15 \\
\hline White & 3 & .0 & .12 & .06 & .07 & .05 \\
\hline & 6 & & & & & .09 \\
\hline Tennessee River & 6 & .08 & .73 & .30 & .33 & .25 \\
\hline
\end{tabular}


Table 8.--Summaries of selected constituent values obtained in sub-basins above Watts Bar Dam during the 1972-82 water years--Continued

\begin{tabular}{|c|c|c|c|c|c|c|}
\hline Sub-basin & $\begin{array}{c}\text { Number of } \\
\text { samples }\end{array}$ & Minimum & Maximum & Median & Mean & $\begin{array}{l}\text { Standard } \\
\text { deviation }\end{array}$ \\
\hline \multicolumn{7}{|c|}{ Phosphorus, total (mg/L as P) } \\
\hline $\begin{array}{l}\text { C1 inch River } \\
\text { above Bull run } \mathrm{Cr} \text {. }\end{array}$ & 1 & & 0.05 & & & \\
\hline Bull run Creek & 27 & 0.01 & 0.11 & 0.03 & 0.03 & 0.02 \\
\hline Poplar Creek & 3 & .02 & .33 & .08 & .14 & .16 \\
\hline Daddys Creek & 1 & & .01 & & & \\
\hline Clear Creek & 2 & .01 & .02 & & & \\
\hline Obed River & 36 & .01 & 4.0 & .13 & .91 & 1.3 \\
\hline Emory River & 60 & .01 & .10 & .02 & .02 & .02 \\
\hline $\begin{array}{l}\text { C1inch River } \\
\text { below Bullrun } \mathrm{Cr} \text {. }\end{array}$ & 90 & .01 & .93 & .07 & .10 & .11 \\
\hline Whites Creek & 3 & .01 & .01 & .01 & & \\
\hline Piney River & 6 & .01 & .04 & .02 & .02 & .01 \\
\hline $\begin{array}{l}\text { Tennessee River } \\
\text { below Fort Loudoun }\end{array}$ & 6 & .02 & .04 & .02 & .02 & .01 \\
\hline \multicolumn{7}{|c|}{ Fecal coliform, $0.45 \mu \mathrm{m}-\mathrm{MF}$ (colonies $/ 100 \mathrm{~mL}$ ) } \\
\hline Bul1 run Creek & 5 & 20 & 630 & 250 & & \\
\hline Obed River & 29 & 10 & 1200 & 200 & & \\
\hline Emory River & 31 & 10 & 670 & 60 & & \\
\hline $\begin{array}{l}\text { Tennessee River } \\
\text { below Fort Loudoun }\end{array}$ & 3 & 10 & 30 & 10 & & \\
\hline \multicolumn{7}{|c|}{ Organic carbon, total (mg/L as C) } \\
\hline Emory River & 8 & 1.0 & 7.2 & $\overline{2.7}$ & 3.3 & 2.6 \\
\hline $\begin{array}{l}\text { Clinch River } \\
\text { below Bullrun } \mathrm{Cr} \text {. }\end{array}$ & 83 & 1.0 & 19 & 5.0 & 5.7 & 4.5 \\
\hline $\begin{array}{l}\text { Tennessee River } \\
\text { below Fort Loudoun }\end{array}$ & 3 & 1.8 & 2.2 & 2.2 & 2.1 & .25 \\
\hline \multicolumn{7}{|c|}{ Suspended sediment $(\mathrm{mg} / \mathrm{L})$} \\
\hline $\begin{array}{l}\text { Clinch River } \\
\text { above Bullrun Cr. }\end{array}$ & 8 & 2.0 & 2170 & 20 & 294 & 760 \\
\hline Poplar Creek & 28 & 2.0 & 685 & 28 & 66 & 130 \\
\hline Daddys Creek & 7 & 3.0 & 379 & 38 & 113 & 150 \\
\hline Clear Creek & 13 & 1.0 & 17 & 3.0 & 5 & 5.6 \\
\hline Obed River & 23 & 13 & 60 & 26 & 27 & 14 \\
\hline Emory River & 26 & 1.0 & 569 & 9.5 & 54 & 120 \\
\hline Whites Creek & 18 & 1.0 & 187 & 6.5 & 22 & 44 \\
\hline Piney River & 10 & 1.0 & 709 & 8.5 & 112 & 230 \\
\hline
\end{tabular}

a Includes summary of data obtained at Obed River mile 1.5 (Map No. OR3, table 4) which is located below confluence with the Daddys Creek and Clear Creek sub-basins. 
Long-term data were generally unavailable at specific stations in the sub-basins to define trends; therefore, trend test results are not presented. Water-quality data obtained at main-channel stations at or above the Watts Bar NASQAN station are summarized in table 9 for selected constituents. Trace constituents obtained at mainchannel stations at or above Watts Bar are summarized in table 10. Water-quality data obtained at main-channel stations at or above Watts Bar Dam were tested for trend using the Seasonal Kendall test and the results are presented in table 11. Trend tests were applied to data unadjusted for the effects of flow for all stations, and also to flow adjusted concentrations for the Emory River station at mile 18.3 (site E1).

\section{Water Type}

Water can be classified on the basis of the predominant inorganic constituents, and the relation between concentrations of constituents helps describe similarities and differences in water quality. Major constituent percent composition of water from main-channel stations and sub-basins of the study area are given in table 12. Water from both the Clinch and Tennessee Rivers is classified as a calcium bicarbonate type, but water from the Emory River is a calcium sulfate bicarbonate type which is believed to be a result of coal-mining activities on the Cumberland Pleateau.

The Seasonal Kendall test was applied to the percent composition data for Watts Bar and the results are shown in table 13. The percentage of individual constituents of the total cations or anions (in milliequivalents) was calculated. Slopes generated by the Seasonal Kendall tests are estimates of the change in percent composition (unitless) per year. Results of the trend tests based on percentage composition cannot estimate increases or decreases in specific constituent concentrations, but rather indicate the proportional change of water type over time. The following changes in the water from Watts Bar can be estimated using the percentage of composition from table 12, and the slope estimates from table 13:
Ratio

Change per year expressed as percent of mean ratio
Ca / Cations
$-0.6$
$\mathrm{Mg} /$ Cations
$+.8$
$(\mathrm{Na}+\mathrm{K}) /$ Cations
$+1.7$
$\mathrm{SO}_{4} /$ Anions
$+4.8$
$\mathrm{Cl} /$ Anions
$+6.3$
$\left(\mathrm{HCO}_{3}+\mathrm{CO}_{3}\right) /$ Anions
$-2.6$

\section{Common Constituents}

\section{Dissolved solids}

Values of median dissolved solids for stations in the Ridge and Valley physiographic province are generally higher than those for stations on the Cumberland Plateau (table 7). Two major sources of dissolved solids are indicated in the study area; dissolved calcium, magnesium, and bicarbonate from dissolution of the carbonate rocks of the Ridge and Valley, and dissolved sulfate resultant from mining activities of the Cumberland Plateau.

In general, concentrations of dissolved solids in streams of the study area show an increasing trend, at least in the Clinch and Emory River basins (table 11). No significant trend is evident in dissolved-solids concentrations in the Tennessee River as flow enters the study area at Fort Loudoun Dam, but an increasing trend is indicated at Watts Bar Dam. An increasing trend of dissolved solids is indicated on the Clinch River at mile 78.8 as it enters the study area at Norris Dam, and at mile 23.1 below Melton Hill Dam. However, data on the Clinch River at miles 66.3 and 48.6 , although indicating the possibility of an increasing trend, are not considered to define a significant trend. Data on the Emory River at mile 18.3 indicate an increasing trend in dissolved solids.

\section{Specific conductance}

Specific conductance is a measure of the ability of water to conduct an electrical current and is related to the quantity and types of ionized substances in water. Specific conductance can be 
Table 9.--Summary of water-quality parameters obtained at main-channel stations at or above Watts Bar Dam during the 1972-82 water years

[Estimated median, value estimated from specific-conductance regressions using the median value of continuous conductance record for the Tennessee River at mile 529.9 (site T19)]

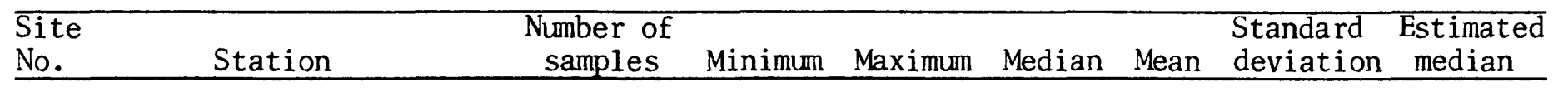

Dissolved solids, residue at $180{ }^{\circ} \mathrm{C}(\mathrm{mg} / \mathrm{L})$

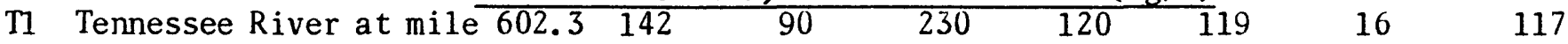

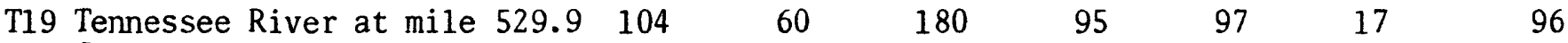

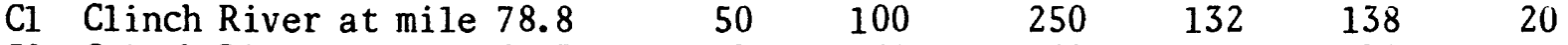

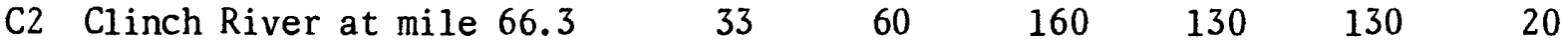

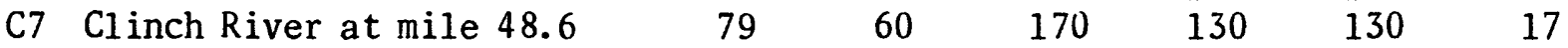

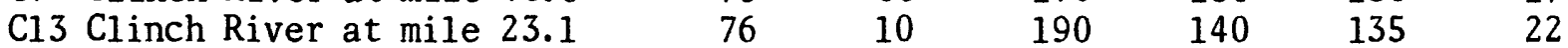

$\begin{array}{llllrrrr}\text { El Enory River at mile } 18.3 & 68 & 20 & 192 & 40 & 50 & 28 & 50\end{array}$

Specific conductance (microsiemens per centimeter at $25{ }^{\circ} \mathrm{C}$ )

$\begin{array}{llrrrrrrr}\text { T1 } & \text { Tennessee River at mile } 602.3 & 63 & 140 & 270 & 200 & 195 & 28 & 196 \\ \text { T3 } & \text { Tennessee River at mile 592.3 } & 54 & 101 & 230 & 160 & 159 & 26 & 164 \\ \text { T8 Tennessee River at mile 560.8 } & 14 & 125 & 250 & 167 & 169 & 32 & \\ \text { T11 Tennessee River at mile 555.7 } & 14 & 113 & 260 & 167 & 169 & 36 & \\ \text { T13 Tennessee River at mile 553.9 } & 14 & 126 & 260 & 171 & 173 & 34 & \\ \text { T15 Tennessee River at mile 548.5 } & 14 & 125 & 260 & 170 & 173 & 35 & \\ \text { T17 Tennessee River at mile 532.1 } & 12 & 154 & 251 & 178 & 179 & 26 & \\ \text { T19 Tennessee River at mile 529.9 } & 127 & 97 & 320 & 160 & 162 & 28 & 161 \\ \text { C1 Clinch River at mile 78.8 } & 54 & 160 & 440 & 230 & 229 & 36 & \\ \text { C2 Clinch River at mile 66.3 } & 38 & 200 & 270 & 220 & 222 & 16 & \\ \text { C3 Clinch River at mile 58.8 } & 11 & 210 & 250 & 230 & 227 & 13 & \\ \text { C7 Clinch River at mile 48.6 } & 84 & 94 & 310 & 220 & 221 & 30 & \\ \text { C13 Clinch River at mile 23.1 } & 86 & 156 & 290 & 235 & 232 & 25 & 233 \\ \text { C14 Clinch River at mile 10.0 } & 54 & 173 & 370 & 247 & 246 & 33 & 248 \\ \text { E1 Emory River at mile 18.3 } & 105 & 37 & 305 & 60 & 79 & 43 & 77 \\ \text { E2 Emory River at mile 14.9 } & 58 & 18 & 360 & 60 & 78 & 50 & 82\end{array}$

T1 Tennessee River at mile 602.3

$63 \frac{\mathrm{pH} \text { (standard units) }}{6.2} \quad 7.0$

$\begin{array}{llllll}\text { T17 Tennessee River at mile } & 532.1 & 12 & 7.3 & 8.2 & 7.6\end{array}$

$\begin{array}{llllll}\text { T19 Tennessee River at mile } & 529.9 & 123 & 6.0 & 8.9 & 7.5\end{array}$

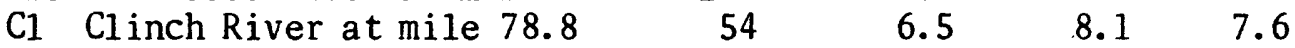

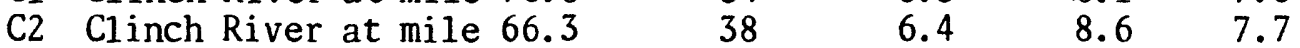

$\begin{array}{llllll}\text { C7 Clinch River at mile } & 48.6 & 72 & 6.4 & 8.6 & 7.6\end{array}$

$\begin{array}{llllll}\mathrm{C} 13 \mathrm{Cl} \text { inch River at mile } 23.1 & 88 & 6.8 & 8.6 & 7.7\end{array}$

$\begin{array}{llllll}\text { E1 Emory River at mile } 18.3 & 76 & 4.9 & 8.5 & 6.8\end{array}$ 
Table 9.--Sumnary of water-quality parameters obtained at main-channel stations at or above Watts Bar Dam during the 1972-82 water years--Continued

\begin{tabular}{|c|c|c|c|c|c|c|c|c|}
\hline \multirow[t]{2}{*}{$\begin{array}{l}\text { Site } \\
\text { No. }\end{array}$} & Station & $\begin{array}{l}\text { umber of } \\
\text { samples }\end{array}$ & Minimum & Maximum & Median & Mean & $\begin{array}{l}\text { Standard } \\
\text { deviation }\end{array}$ & $\begin{array}{c}\text { Estimat } \\
\text { median }\end{array}$ \\
\hline & \multicolumn{8}{|c|}{ Dissolved sulfate $\left(\mathrm{mg} / \mathrm{L}\right.$ as $\left.\mathrm{SO}_{4}\right)$} \\
\hline $\mathrm{T} 1$ & Tennessee River at mile 602.3 & 3150 & 2.0 & 37 & 18 & 17 & 4.1 & 16 \\
\hline T3 & Tennessee River at mile 592.3 & 3110 & 3.0 & 61 & 11 & 12 & 8.2 & 9.5 \\
\hline T19 & Tennessee River at mile 529.9 & 110 & 3.0 & 20 & 13 & 13 & 2.6 & 13 \\
\hline $\mathrm{Cl}$ & Clinch River at mile 78.8 & 51 & 7.0 & 25 & 18 & 18 & 3.3 & \\
\hline $\mathrm{C} 2$ & $\mathrm{Cl}$ inch River at mile 66.3 & 33 & 14 & 32 & 16 & 18 & 4.3 & \\
\hline $\mathrm{C} 7$ & Clinch River at mile 48.6 & 67 & 11 & 40 & 17 & 17 & 4.8 & \\
\hline $\mathrm{Cl3}$ & Clinch River at mile 23.1 & 81 & 4.0 & 24 & 17 & 17 & 3.9 & 17 \\
\hline $\mathrm{Cl} 4$ & Clinch River at mile 10.0 & 56 & 4.0 & 68 & 17 & 20 & 11 & \\
\hline E1 & Emory River at mile 18.3 & 71 & 3.0 & 86 & 13 & 17 & 12 & 17 \\
\hline E2 & Enory River at mile 14.9 & 88 & 7.0 & 35 & 12 & 14 & 6.5 & 13 \\
\hline
\end{tabular}

\begin{tabular}{llrrrrrr} 
& \multicolumn{7}{c}{ Iron, total recoverable $(\mu \mathrm{g} / \mathrm{L})$} \\
T1 & Tennessee River at mile 602.3 & 141 & 50 & 1900 & 390 & 446 & 245 \\
T3 & Tennessee River at mile 592.3 & 111 & 70 & 3800 & 600 & 758 & 658 \\
T19 Tennessee River at mile 529.9 & 76 & 70 & 2500 & 322 & 415 & 338 \\
C1 & Clinch River at mile 78.8 & 48 & 10 & 840 & 80 & 136 & 158 \\
C2 & Clinch River at mile 66.3 & 37 & 10 & 1600 & 90 & 285 & 413 \\
C7 & Clinch River at mile 48.6 & 79 & 20 & 8600 & 290 & 457 & 974 \\
C13 C1inch River at mile 23.1 & 67 & 80 & 1000 & 290 & 356 & 221 \\
C14 Clinch River at mile 10.0 & 56 & 25 & 2600 & 400 & 550 & 553 \\
E1 Emory River at mile 18.3 & 66 & 50 & 3700 & 245 & 398 & 519 \\
E2 & Emory River at mile 14.9 & 89 & 70 & 2800 & 390 & 633 & 587
\end{tabular}

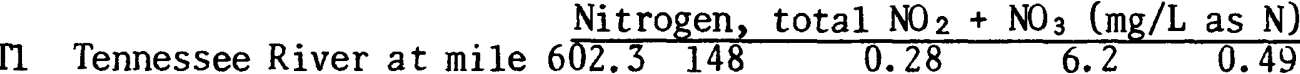

T3 Tennessee River at mile $592.3 \quad 102$

T17 Tennessee River at mile $532.1 \quad 10$

T19 Tennessee River at mile $529.9 \quad 107$

C1 Clinch River at mile 78.8

C2 Clinch River at mile 66.3

C7 Clinch River at mile 48.6

C13 Clinch River at mile 23.1

$\mathrm{Cl} 4 \mathrm{Cl}$ inch River at mile 10.0

EI Emory River at mile 18.3

E2 Emory River at mile 14.9

$38 \quad .19$

$21 \quad .19$

$67 \quad .12$

$80 \quad .09$

$99 \quad .01$

$54 \quad .01$

89

.01
1.1

.55

.68

1.1

.72

1.1

4.0

1.5

.39
.44

.25

.35

.51

.46

.50

.52

.42

.14

.15
0.60

.44

.29

.36

.54

.47

.48

.56

.44

.15

.20
0.58

.16

.15

.12

.24

.17

.18

.47

.27

.10

.16
0.14 .14 
Table 9.--Summary of water-quality parameters obtained at main-channel stations at or above Watts Bar Dam during the 1972-82 water years--Continued

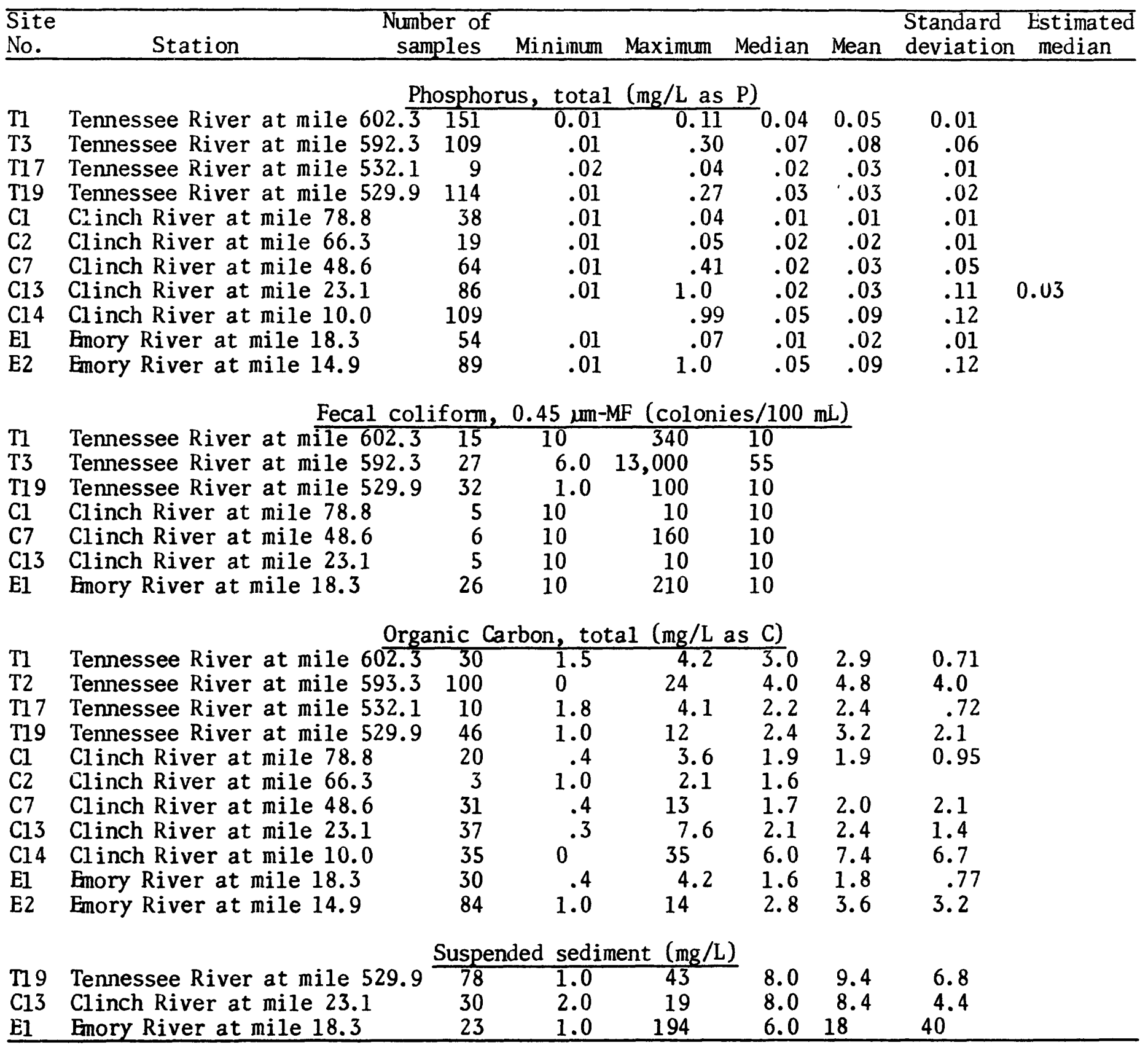


Table 10. --Summary of trace-constituent data obtained at main-channel stations at or above Watts Bar Dam during the 1972-82 water years

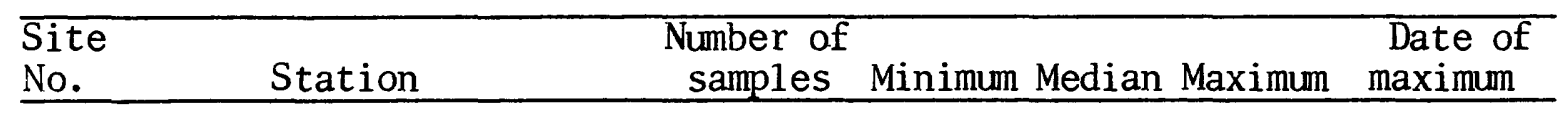

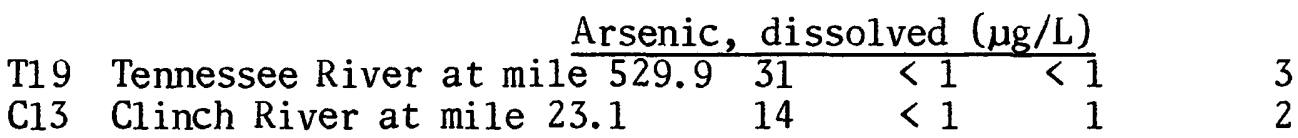

\begin{tabular}{|c|c|c|c|c|c|c|}
\hline & Arsenic, tot & $a 1$ & overa & $(\mu$ & & \\
\hline $\mathrm{T} 1$ & Tennessee River at mile 602.3 & 17 & $<2$ & $<5$ & $<10$ & \\
\hline $\mathrm{T} 3$ & Tennessee River at mile 592.3 & 58 & $<1$ & $<1$ & $<20$ & \\
\hline T19 & Tennessee River at mile 529.9 & 47 & $<1$ & $<2$ & $<10$ & \\
\hline $\mathrm{C} 1$ & Clinch River at mile 78.8 & 6 & $<2$ & $<5$ & $<5$ & \\
\hline $\mathrm{C} 2$ & Clinch River at mile 66.3 & 3 & $<2$ & $<2$ & $<2$ & \\
\hline C7 & C1inch River at mile 48.6 & 36 & $<2$ & $<4$ & 9 & $4-5-77$ \\
\hline $\mathrm{C} 13$ & Clinch River at mile 23.1 & 29 & $<1$ & $<5$ & 6 & $6-18-75$ \\
\hline $\mathrm{Cl} 4$ & Clinch River at inile 10.0 & 64 & $<1$ & $<1$ & 25 & $10-4-76$ \\
\hline E1 & Emory River at mile 18.3 & 17 & 1 & $<5$ & 7 & $8-12-75$ \\
\hline F? & Emory River at mile 14.9 & 62 & $<1$ & $<1$ & 4 & $9-1-74$ \\
\hline
\end{tabular}

Cadmium, dissolved ( $\mu \mathrm{g} / \mathrm{L})$

T19 Tennessee River at mile $\begin{array}{llll}529.9 & 31 & \text { ND ND } & \text { ND }\end{array}$

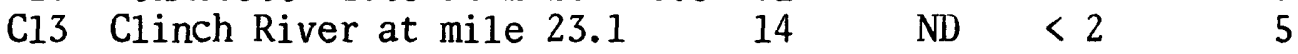

T1 Tennessee River at $\frac{\text { Cadmium, total recoverable }(\mu \mathrm{g} / \mathrm{L})}{\mathrm{mile} 602.3123<2<2}$

T19 Tennessee River at mile 529.9

Cl Clinch River at mile 78.8 23

$85<2$

$2<2$

$\mathrm{ND}<2$

$23<2<2$

2

C2 Clinch River at mile 66.3

C7 Clinch River at mile 48.6

$3<2$

$<2$

$35<2$

$<2$

$<2$

C13 Clinch River at mile 23.1

38

ND

C14 Clinch River at mile 10.0

E1 Emory River at mile 18.3

65

$<2$

$<2$

$<2$

34

ND

$<2$

E2 Emory River at mile 14.9

89

ND

$11-11-74$

240

8- $9-72$

8- 5-75

$<2$

$<2$

$<2$

4

3-12-74

$20 \quad 5-18-77$

$<2$

11- 1-77

T19 Tennessee River at mile $\frac{\text { Chromium, dissolved (ug/L) }}{529.9} 31$ ND 6

C13 Clinch River at mile 23.1

$14<20<20$

12- 3-79

Chromium, tota1 recoverable ( $\mathrm{\mu g} / \mathrm{L}$ )

T1 Tennessee River at mile 602.3 16

T3 Tennessee River at mile $592.3 \quad 84$

T19 Tennessee River at mile 529.947

$\mathrm{Cl}$ Clinch River at mile 78.8

C2 Clinch River at mile 66.3

C7 Clinch River at mile 48.6

C13 Clinch River at mile 23.1

C14 Clinch River at mile 10.0

E1 Emory River at mile 18.3

E2 Emory River at mile 14.9

\section{6}

3

35

29

64

17

84
$<2$

$<2$

$<5$

$<5$

$<5$

$<5$

$<2$

$<5$

$<2$
$<2$

8

$<5$

$<5$

$<5$

$<5$

$<2$

$<5$

$<2$
$<5$

14

$<5$

51 3- 7-78

$30 \quad 7-10-79$

$<40$

36 8- 9-76

21 9- $1-80$ 
Table 10.--Summary of trace-constituent data obtained at main-channel stations at or above Watts Bar Dam during the 1972-82 water years - -Continued

\begin{tabular}{llcc}
\hline Site & Number of & Date of \\
No. & Station & samples Minimum Median Maximum maximum \\
\hline
\end{tabular}

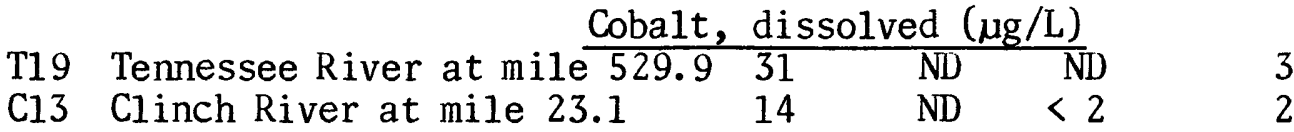

T1 Tennessee River at $\frac{\text { Cobalt, total recoverable }(\mathrm{ug} / \mathrm{L})}{\mathrm{mile} 602.32}<5$

T19 Tennessee River at mile $529.927 \quad$ ND $272<5$

C13 Clinch River at mile $23.1 \quad 15 \quad$ ND $<2<5$

E1 Emory River at mile $18.3<5<5$

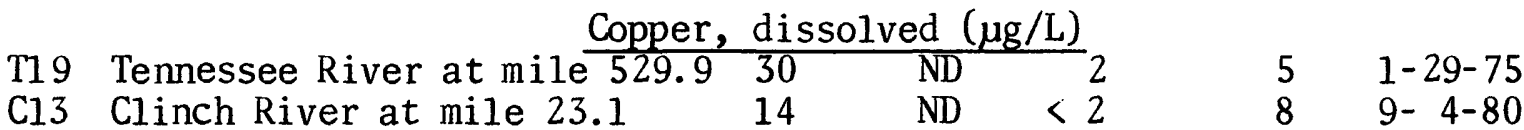

Copper, total recoverable ( $\mu \mathrm{g} / \mathrm{L})$

T1 Tennessee River at mile 602.3 $125<20<20$

$840 \quad 9-27-74$

T3 Tennessee River at mile $592.3 \quad 85$

$2 \quad 117$

1350

470

T19 Tennessee River at mile 529
C1 Clinch River at mile 78.8

$\mathrm{ND}<20$

140

C2 Clinch River at mile 66.3

23

$<20$

$<20$

$20 \quad 600$

5400

220

C7 Clinch River at mile 48.6

37

$<20$

45

C13 Clinch River at mile 23.1

39

$<2$

12

$65<20<20$

C14 Clinch River at mile 10.0

34

5

$<20$

E2 Emory River at mile 14.9

89

$13 \quad 239$

4- 1-80

5-23-78

$11-20-78$

4-28-77

$1-15-74$

80 5-15-78

$20 \quad 8-9-72$

$40 \quad 11-8-76$

1850 9- $1-74$

Lead, dissolved ( $\mu \mathrm{g} / \mathrm{L})$

T19 Tennessee River at mile $\begin{array}{lll}529.9 & 30 & \text { ND }\end{array}$

C13 C1inch River at mile 23.1

14

ND

$<2$

$8 \quad 6-13-77$

4 6-22-81

Lead, total recoverable ( $\mu \mathrm{g} / \mathrm{L})$

T1 Tennessee River at mile $602.3123 \quad<2<10$

T3 Tennessee River at mile $592.386<\begin{array}{lll}5 & 10\end{array}$

T19 Tennessee River at mile 529.948

ND $<10$

C1 Clinch River at mile 78.8

23

$<10$

$<10$

$<10$

21

C7 Clinch River at mile 48.6

$35<10$

$<10$

39

ND

$<10$

$66<2<10$

34

89

$<5$

$<10$

$<10$

8- 9-72

2- 4-75

3-15-77

27

19 11- 2-76

33 3-11-75

C14 Clinch River at mile 10.0

E2 Emory River at mile 14.9

Manganese, dissolved ( $\mathrm{mg} / \mathrm{L})$

T1 Tennessee River at mile 602.3 13

T19 Tennessee River at mile 529.948

C1 Clinch River at mile 78.8

C13 Clinch River at mile 23.1

8

$<10$

20

$<10$

$<10$

100

8- 9-72

22

5- 6-75

E1 Fmory River at mile 18.3

18

$<10$

35

75

$4-18-73$

410

8- 4-76

$40 \quad 11-19-80$

$71<10 \quad 50$

140

$11-6-74$ 
Table 10. --Summary of trace-constituent data obtained at main-channel stations at or above Watts Bar Dam during the 1972-82 water years - - Continued

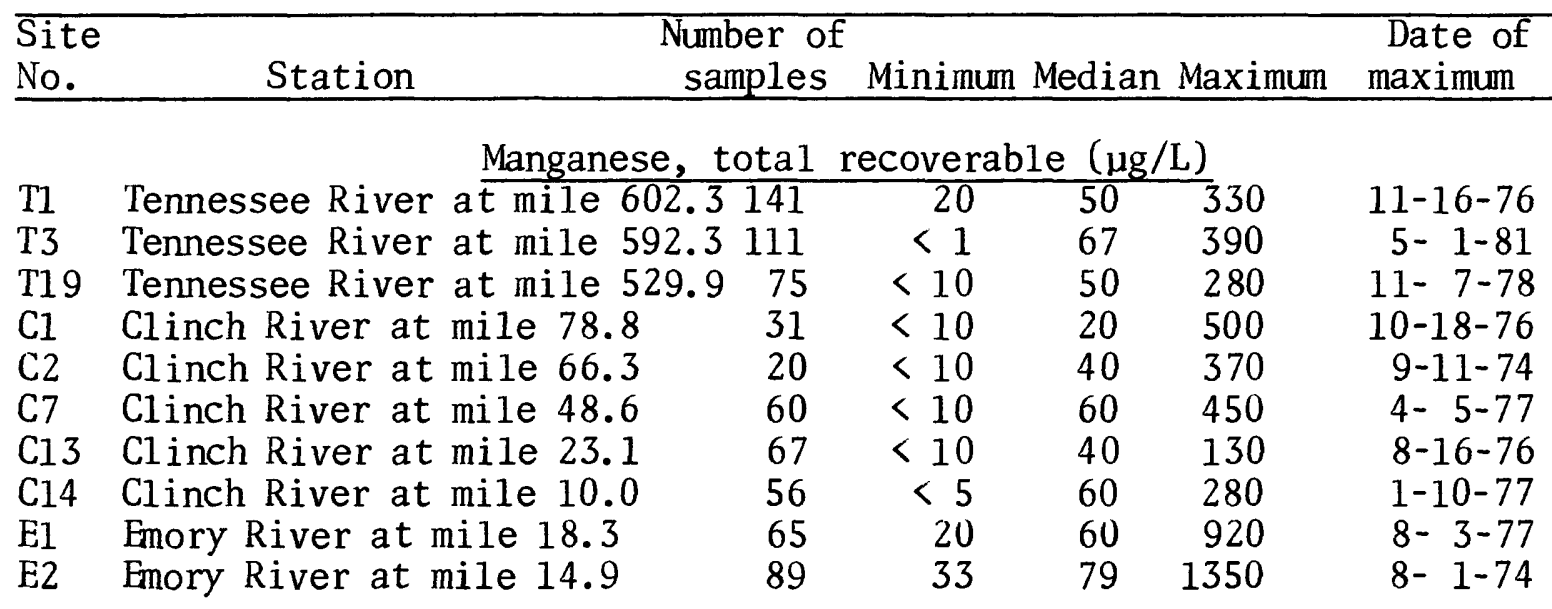

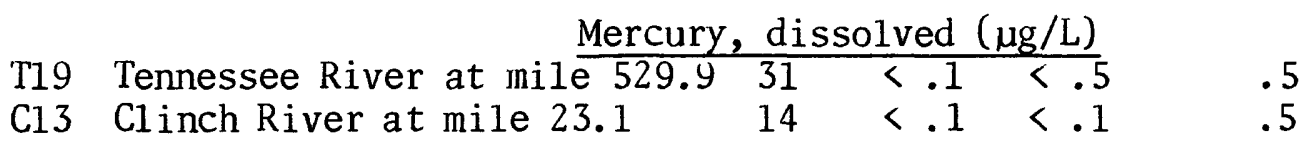

Mercury, total recoverable $(\mu \mathrm{g} / \mathrm{L})$

T1 Tennessee River at mile 602.3 $120<.2<.2$

T3 Tennessee River at mile $592.37<.2<.2$

T19 Tennessee River at mile $529.949<.1<.2$

C1 Clinch River at mile 78.8

C2 Clinch River at mile 66.3

C7 Clinch River at mile 48.6

C13 Clinch River at mile 23.1

C14 Clinch River at mile 10.0

El Emory River at mile 18.3

$23<.2<.2$

$3<.2<.5$

$34<.2<.2$

7.6

$3-12-74$

$<.5$

.9 5-15-74

$2.21-21-80$

$38<.1<.2$

$64<.2<.2$

$33 \quad .1<.2$

$<.5$

$<.5$

$9.14-23-74$

$<1.0$

$1.45-13-74$

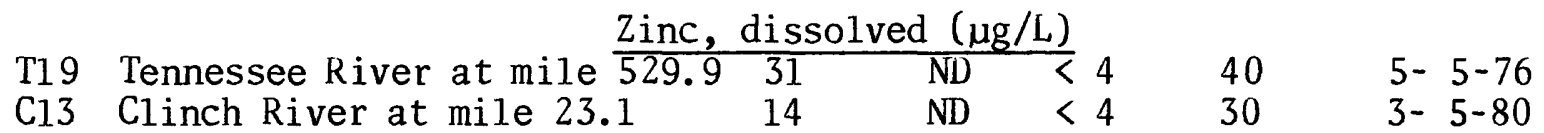

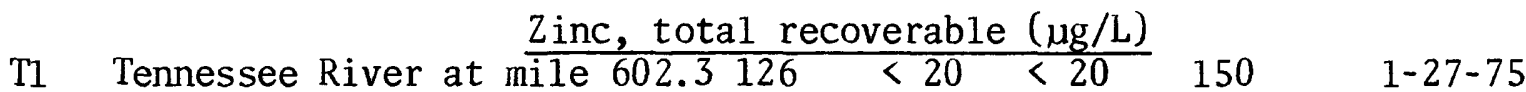

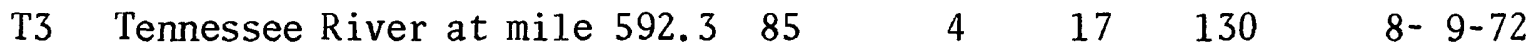

T19 Tennessee River at mile 529.9 $49 \quad<20 \quad 20 \quad 160 \quad 5-23-78$

C1 Clinch River at mile 78.8 $23 \quad<20 \quad 40 \quad 150 \quad 6-12-77$

$\begin{array}{lllllll}\text { C. Clinch River at mile } 66.3 & 3 & 50 & 80 & 200 & 12-7-76\end{array}$

$\begin{array}{lllllll}\text { C7 Clinch River at mile 48.6 } & 35 & <20 & 70 & 150 & 7-11-78\end{array}$

$\begin{array}{lllllll}\text { C13 Clinch River at mile 23.1 } & 39 & 9 & 20 & 90 & 6-18-74\end{array}$

C14 Clinch River at mile $10.0 \quad 11<2<20 \quad 63 \quad 5-30-79$

El Emory River at mile $18.3 \quad 34<20 \quad 20 \quad 90 \quad 5-4-77$

E2 Emory River at mile $14.9 \quad 89 \quad<2 \quad 14 \quad 112 \quad 6-1-79$ 
Table 11. - Trends in water-quality parameters obtained at main-channel stations at or above Watts Bar Dam

[Flow adjustment equation used: HYP, hyperbolic; INV, inverse; QAD, quadratic; LOG, logarithmic; NST indicates no significant trend at the 90 percent confidence interval; a, Units means the individual constituent reporting units; for example milligrams per liter. However, if a logarithmic flow adjustment equation is used the slope is unitless ]

\begin{tabular}{llcccc}
\hline Site & Station & N & Slope & & Water \\
No. & Nvals & Tau & level & (units/yr)a Notes & years \\
\hline
\end{tabular}

$$
\text { Dissolved solids, residue at } 180^{\circ} \mathrm{C}(\mathrm{mg} / \mathrm{L})
$$

T1 Tennessee River at mile 602.3 $49-0.122 \quad 0.426$

T19 Tennessee River at mile $529.9 \quad 86 \quad .216 \quad .019$

C1 Clinch River at mile 78.8

$50 \quad .411 \quad .003$

1.42

C2 Clinch River at mile 66.3

$33 \quad .094 \quad .751$

C7 Clinch River at mile 48.6

$\begin{array}{lll}68 & .121 & .272\end{array}$

C13 C1inch River at mile 23.1

$\begin{array}{lll}66 & .382 \quad .001\end{array}$

1.16

$63 \quad .383$

.001

$\begin{array}{lll}62 & .328 \quad .005\end{array}$

$\begin{array}{ll}\text { NST } & 74-80 \\ & 74-82 \\ & 72-80 \\ \text { NST } & 72-77 \\ \text { NST } & 72-78 \\ & 74-82 \\ & 74-81 \\ \text { INV } & 74-81\end{array}$

Specific conductance (microsiemens per centimeter at $25^{\circ} \mathrm{C}$ )

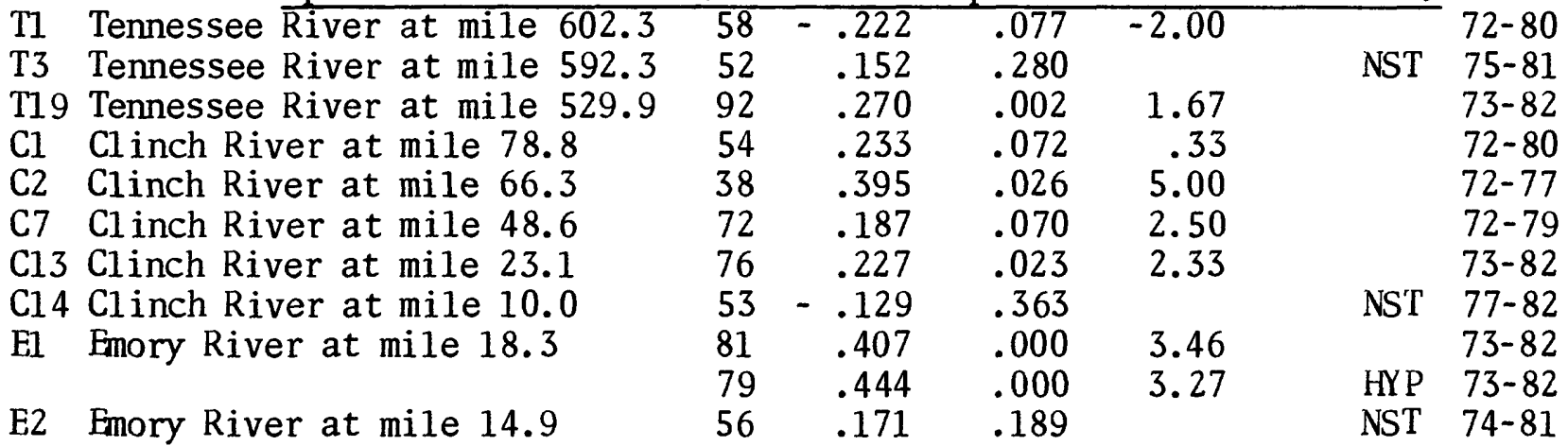

T1 Tennessee River at mile 602.3

T19 Tennessee River at mile 529.9

C1 Clinch River at mile 78.8

C2 Clinch River at mile 66.3

C7 Clinch River at mile 48.6

C13 Clinch River at mile 23.1

El Emory River at mile 18.3
$\mathrm{pH}$ (standard units)

$\begin{array}{rrr}58 & .060 & .668 \\ 90 & -.046 & .625 \\ 54 & .046 & .772 \\ 38 & -.047 & .887 \\ 60 & .117 & .348 \\ 77 & .091 & .375 \\ 69 & .0512 & 0\end{array}$

NST $\quad 72-80$

NST 73-82

NST $72-80$

NST 72-77

NST $72-79$

NST $73-82$

74-81

NST $\quad 72-80$

$72-82$

$73-82$

$72-80$

NST $\quad 72-77$

$72-78$

73-82

NST $\quad 72-77$

$73-81$

LOG 73-81

NST 74-82 $\begin{array}{llll}65 & .467 & .000 & .88\end{array}$

$\begin{array}{llll}63 & .307 & .008 & .65\end{array}$

$84 \quad .052 \quad .583$ 
Table 11.--Trends in water-quality parameters obtained at main-channel stations at or above Watts Bar Dam--Continued

\begin{tabular}{|c|c|c|c|c|c|c|c|}
\hline $\begin{array}{l}\text { Site } \\
\text { No. }\end{array}$ & Station & Nvals & $\mathrm{Tau}$ & $\begin{array}{c}\mathrm{P} \\
\text { level }\end{array}$ & $\begin{array}{c}\text { Slope } \\
\text { (units/yr) }\end{array}$ & Notes & $\begin{array}{l}\text { Water } \\
\text { years }\end{array}$ \\
\hline \multicolumn{8}{|c|}{ Iron, total recoverable ( $\mu \mathrm{g} / \mathrm{L})$} \\
\hline $\mathrm{T} 1$ & Tennessee River at mile $\overline{602.3}$ & $\overline{48}$ & -0.346 & 0.019 & -56.7 & & $72-79$ \\
\hline T3 & see River at mile 59 & 104 & -.258 & .001 & -35 & & $72-82$ \\
\hline T19 & see River at mile 52 & 70 & -.500 & .000 & -34 & & 82 \\
\hline $\mathrm{Cl}$ & Clinch River at mile 7.8 .8 & 48 & .545 & .000 & 20 . & & $72-79$ \\
\hline $\mathrm{C} 2$ & Clinch River at mile 66.3 & 37 & .714 & .000 & 40. & & $72-77$ \\
\hline $\mathrm{C} 7$ & Clinch River at mile 48.6 & 73 & .267 & .010 & 32.5 & & $72-79$ \\
\hline $\mathrm{C} 13$ & Clinch River at mile 23.1 & 64 & -.269 & .018 & -22.0 & & $73-82$ \\
\hline $\mathrm{C} 14$ & h River at mile 10.0 & 5 & -.151 & .255 & & & $72-77$ \\
\hline $\mathrm{E} 1$ & Emory River at mile 18.3 & 6 & -.05 & .436 & & NS & \\
\hline & & & -.16 & .171 & & & \\
\hline 52 & Emory River at mile 14.9 & 84 & .366 & & -80.0 & & -82 \\
\hline
\end{tabular}

$\begin{array}{llcccccr} & & \text { Nitrogen, total } & \mathrm{NO}_{2}+\mathrm{NO}_{3} \text { (mg/L as N) } & & \\ \text { T1 Tennessee River at mile 602.3 } & 55 & -.095 & .496 & & & \text { NST } & 73-80 \\ \text { T3 Tennessee River at mile 592.3 } & 96 & .009 & .945 & & \text { NST } & 73-82 \\ \text { T19 Tennessee River at mile 529.9 } & 85 & -.253 & .006 & -.01 & & 73-82 \\ \text { C1 C1inch River at mile 78.8 } & 38 & .319 & .082 & .04 & & 75-80 \\ \text { C7 } & \text { C1inch River at mile 48.6 } & 55 & .297 & .023 & .03 & & 74-79 \\ \text { C13 C1inch River at mile 23.1 } & 70 & -.136 & .209 & & \text { NST } & 73-81 \\ \text { C14 C1inch River at mile 10.0 } & 98 & -.126 & .134 & & \text { NST } & 73-82 \\ \text { E1 Emory River at mile 18.3 } & 53 & .216 & .108 & & \text { NST } & 73-80 \\ \text { E2 Emory River at mile 14.9 } & 84 & .547 & 0 & .03 & & 74-82\end{array}$

Phosphorus, total (mg/L as P)

\begin{tabular}{|c|c|c|c|c|c|c|c|}
\hline $\mathrm{T} 1$ & Tennessee River at mile $6 \overline{02.3}$ & 58 & -.333 & .007 & .002 & & $72-80$ \\
\hline T3 & Tennessee River at mile 592.3 & 103 & -.254 & .001 & -.005 & & $72-82$ \\
\hline $\mathrm{T} 19$ & Tennessee River at mile 529.9 & 91 & .010 & .940 & & NST & $73-82$ \\
\hline $\mathrm{C} 1$ & Clinch River at mile 78.8 & 38 & .213 & .215 & & NST & $75-80$ \\
\hline $\mathrm{C7}$ & $\mathrm{Cl}$ inch River at mile 48.6 & 53 & .0 & 1.000 & & NST & $74-79$ \\
\hline $\mathrm{C} 13$ & Clinch River at mile 23.1 & 76 & .0 & 1.000 & & NST & $73-82$ \\
\hline $\mathrm{C} 14$ & Clinch River at mile 10.0 & 108 & .103 & .187 & & NST & 7 \\
\hline $\mathrm{E} 1$ & Emory River at mile 18.3 & 53 & .175 & .176 & & NST & 80 \\
\hline E2 & Emory River at mile 14.9 & 85 & .150 & .006 & -.007 & & \\
\hline
\end{tabular}

Fecal coliform, $0.45 \mu \mathrm{m}-\mathrm{MF}$ (colonies/100 mL)

$\begin{array}{llrrrrr}\text { T3 Tennessee River at mile } 592.3 & 27 & -.368 & .197 & \text { NST } & 72-82 \\ \text { T19 } & \text { Tennessee River at mile 529.9 } & 26 & -.080 & .860 & \text { NST } & 72-82 \\ \text { E1 Emory River at mile 18.3 } & 26 & .174 & .551 & \text { NST } & 73-82 \\ & & 24 & .053 & 1.000 & \text { NST QAU } & 73-82\end{array}$


Table 11.--Trends in water-quality parameters obtained at main-channel stations at or above Watts Bar Dam--Continued

\begin{tabular}{|c|c|c|c|c|c|c|c|}
\hline $\begin{array}{l}\text { Site } \\
\text { No. }\end{array}$ & Station & Nvals & Tau & $\begin{array}{c}\mathrm{P} \\
\text { 1 eve1 }\end{array}$ & $\begin{array}{c}\text { Slope } \\
\text { (units/yr) }\end{array}$ & Notes & $\begin{array}{l}\text { Water } \\
\text { years } \\
\end{array}$ \\
\hline $\begin{array}{l}\text { T1 } \\
\text { T3 } \\
\text { T19 } \\
\text { C1 } \\
\text { C7 } \\
\text { C13 } \\
\text { C14 } \\
\text { E1 } \\
\text { E2 }\end{array}$ & $\begin{array}{l}\text { Tennessee River at mile } \frac{\text { Organi }}{602.3} \\
\text { Tennessee River at mile } 592.3 \\
\text { Tennessee River at mile } 529.9 \\
\text { Clinch River at mile } 78.8 \\
\text { Clinch River at mile } 48.6 \\
\text { Clinch River at mile } 23.1 \\
\text { Clinch River at mile } 10.0 \\
\text { Emory River at mile } 18.3 \\
\text { Emory River at mile } 14.9\end{array}$ & $\begin{array}{c}\text { carbc } \\
30 \\
95 \\
41 \\
20 \\
28 \\
34 \\
35 \\
30 \\
80\end{array}$ & $\begin{array}{l}\frac{1, \text { tot }}{0.351} \\
-.219 \\
.198 \\
.333 \\
0 \\
.104 \\
.073 \\
.095 \\
-.121\end{array}$ & $\begin{array}{r}(\mathrm{mg} / \mathrm{L} \\
0.110 \\
.010 \\
.201 \\
.359 \\
1.000 \\
.640 \\
.789 \\
.706 \\
.198\end{array}$ & as C) & $\begin{array}{l}\text { NST } \\
\text { NST } \\
\text { NST } \\
\text { NST } \\
\text { NST } \\
\text { NST } \\
\text { NST }\end{array}$ & $\begin{array}{l}74-80 \\
72-82 \\
73-82 \\
75-80 \\
74-78 \\
73-82 \\
72-77 \\
73-80 \\
74-82\end{array}$ \\
\hline $\begin{array}{l}\text { T19 } \\
\text { C13 } \\
\text { E1 }\end{array}$ & $\begin{array}{l}\text { Tennessee River at mile } 529.9 \\
\text { Clinch River at mile } 23.1 \\
\text { Emory River at mile } 18.3\end{array}$ & $\begin{array}{c}\text { ende } \\
74 \\
24 \\
22 \\
22\end{array}$ & $\begin{array}{l}\text { sedim } \\
-.175 \\
-.550 \\
-.833 \\
-.167\end{array}$ & $\begin{array}{c}(\mathrm{mg} / \mathrm{l} \\
.087 \\
.043 \\
.014 \\
.784\end{array}$ & $\begin{array}{l}-.33 \\
-1.88 \\
-8.00\end{array}$ & NST QAD & $\begin{array}{l}72-82 \\
72-82 \\
73-82 \\
73-82\end{array}$ \\
\hline
\end{tabular}


Table 12.--Mean values of milliequivalent ratios expressed as percent of cations $(\mathrm{Ca}+\mathrm{Mg}+\mathrm{Na}+\mathrm{K})$ or anions $\left(\mathrm{SO}_{4}+\mathrm{Cl}+\mathrm{HOO}_{3}+\mathrm{CO}_{3}\right)$

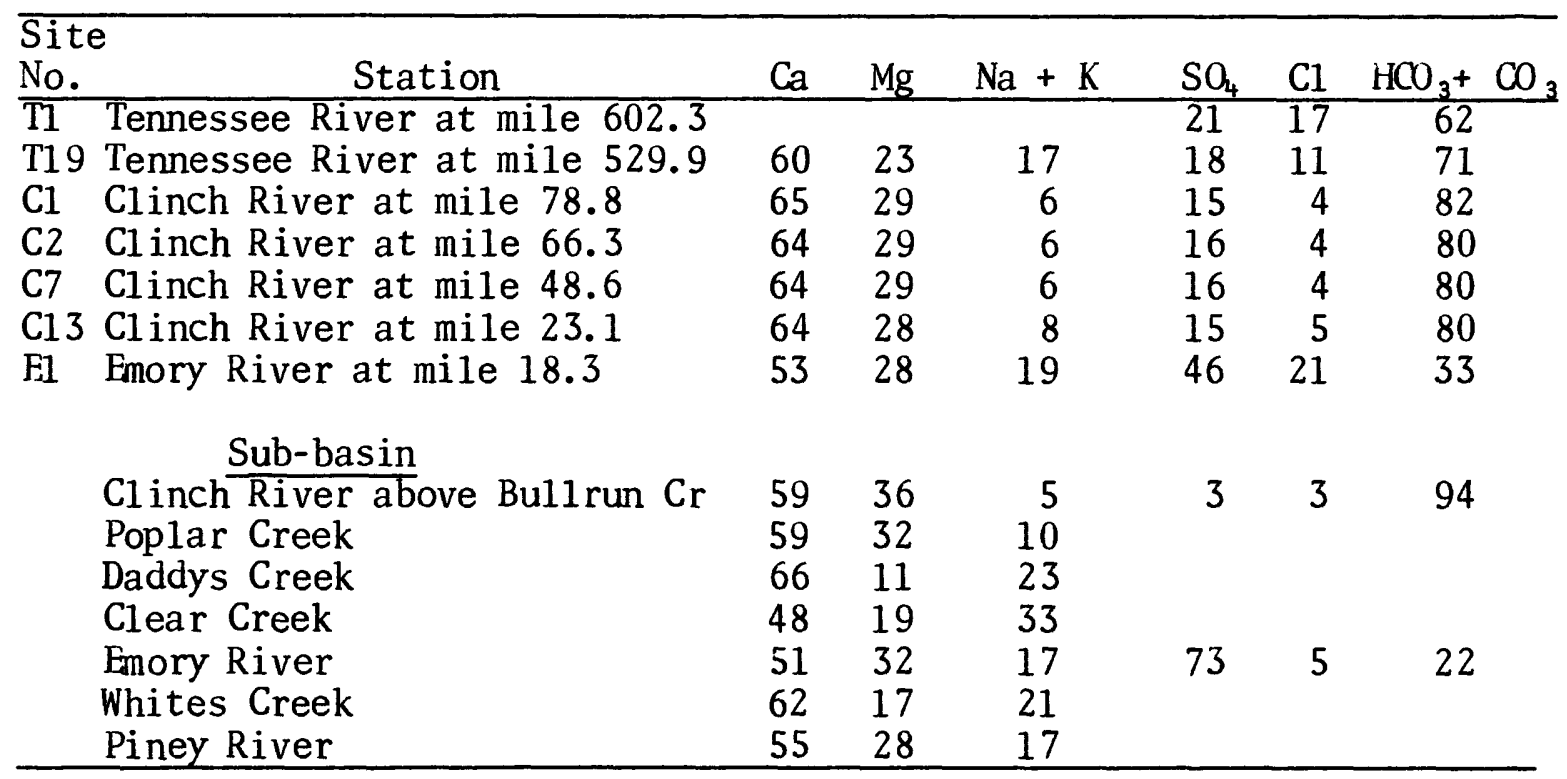

Table 13. --Trend test of percent composition data for the Watts Bar NASQAN station ( site T19)

\begin{tabular}{lrrrr}
\hline Composition & Nvals & Tau & level & Slope \\
\hline $\mathrm{Ca}$ & 73 & -0.361 & 0.000 & -0.00363 \\
$\mathrm{Mg}$ & 73 & .144 & $.171^{*}$ & .00186 \\
$\mathrm{Na}+\mathrm{K}$ & 73 & .206 & .048 & .00295 \\
$\mathrm{SO}_{4}$ & 26 & .368 & $.204^{*}$ & .00841 \\
$\mathrm{HCO}_{3}+\mathrm{CO}_{3}$ & 26 & -.368 & $.204^{*}$ & -.01846 \\
$\mathrm{C} 1$ & 26 & .263 & $.397^{*}$ & .00720 \\
\hline
\end{tabular}

*Not significant at the 90 percent confidence interval. 
used as a general indicator of dissolved solids. Median specific-conductance values for stations in the Ridge and Valley physiographic province are generally higher than those for stations on the Cumberland Plateau (table 7). This is in agreement with the dissolved-solids data obtained in the study area.

In general, conductance of water from streams in the study area shows an increasing trend, at least in the Clinch and Emory River basins (table 11). The dissolved-solids trends of the main-channel stations generally agree with the pattern of specific-conductance trends.

Conductance of water from the Tennessee River shows a slight decreasing trend at Fort Loudoun Dam as water enters the study area. Instantaneous observations of specific conductance indicate a slight increasing trend at the outlet of the study area at Watts Bar Dam, which is in agreement with the trend test of continuous specific conductance record. Trend tests of instantaneous specific-conductance observations on the Clinch River between Norris and Melton Hill Dams indicate increased conductance during the 1972-82 water years. This does not agree with the trend test of continuous specific-conductance record of Melton Hill Dam (table 6), perhaps because the daily record reflects only the period 1981-82. The Clinch River at mile 10 does not show a significant trend in conductance. But, since this station is affected by backwater from Watts Bar Reservoir, the data are inconclusive. Trend tests of the Emory River at mile 18.3 indicate an increasing trend in specific conductance, whereas no significant trend is indicated at mile 14.9. No major inflow occurs between these sites, but less data were available for analysis at mile 14.9 than at mile 18.3 which may be the cause for this inconsistency.

Sufficient data for trend analysis were available at only five sub-basin stations. No significant trends were indicated by two stations in the Poplar Creek sub-basin, nor were trends indicated by stations in the Bullrun Creek or Clinch River below Bullrun Creek sub-basins. An increasing conductance trend was indicated at mile 1.5 on the Obed River which includes drainage from the Clear Creek, Daddys Creek, and Obed River sub-basins.
Because of its relation to ionized substances, specific conductance can be used to estimate dissolved-solids concentrations and concentrations of some individual dissolved chemical constituents in water. If a satisfactory set of relations between conductance and other constituents can be developed, individual constituent concentrations can be estimated simply by measuring conductance. Sampling could be directed toward determination of constituents which do not correlate with conductance.

Regression statistics describing the relation between specific conductance and several waterquality constituents were determined for stations on the Clinch, Emory, and Tennessee Rivers. Statistical parameters for these relations are given in table 14. Sufficient data were generally unavailable at stations of the sub-basins for regression analysis. The concentration of a particular constituent can be estimated by the equation:

where

$$
C=R(S C)+B
$$

$\mathrm{C}$ is concentration, in milligrams per liter;

$\mathrm{R}$ is the regression coefficient;

$\mathrm{SC}$ is specific conductance in microsiemens per centimeter at $25^{\circ} \mathrm{C}$; and

$B$ is the regression constant.

Note: The regression equations should be used with caution in estimating concentrations of constituents at some stations due to relatively small sample sizes. To guide the data user, table 14 contains the values of percent explained variance of the relations between conductance and the other constituents, as well as the standard error of estimate for each regression.

A specific-conductance profile of the mainchannel system of the study area based on observations obtained during the same day at several main-channel stations is shown in figure 10 . Also displayed in figure 10 is a profile based on the median values of specific conductance obtained at main-channel stations which had at least 12 observations (see table 9). The median value profiles generally agree with the shapes of the "same-day" profiles and are considered a good representation of specific-conductance variability along the main channels of the study area. 
Table 14.--Regression statistics describing the relations between specific conductance and several water-quality parameters obtained at main-channel stations at or above Watts Bar Dam during the 1972-82 water years

[Al1 relations shown are above the 90 percent confidence interval]

\begin{tabular}{|c|c|c|c|c|c|}
\hline Constituent & $\begin{array}{c}\text { Number } \\
\text { of } \\
\text { comparisons }\end{array}$ & $\underset{R}{\text { Slope }}$ & $\underset{B}{\text { Intercept }}$ & $\begin{array}{l}\text { Standard } \\
\text { error of } \\
\text { estimate }\end{array}$ & $\begin{array}{l}\text { Percent } \\
\text { explained } \\
\text { variance }\end{array}$ \\
\hline
\end{tabular}

Tennessee River at mile 602.3 (site T1)

Specific-conductance range $=140$ to 270 microsiemens

Chloride, dissolved (mg/L as C1) $61 \quad 1.249 \times 10^{-1} \quad-13.2$

Hardness ( $\mathrm{mg} / \mathrm{L}$ as $\mathrm{CaCO}_{3}$ )

$35 \quad 2.524 \times 10^{-1} \quad 21.4$

Sulfate, dissolved ( $\mathrm{mg} / \mathrm{L}$ as $\mathrm{SO}_{4}$ )

$629.679 \times 10^{-2}$

$-3.23$

Silica, dissolved $\left(\mathrm{mg} / \mathrm{L}\right.$ as $\left.\mathrm{SiO}_{2}\right) \quad 23 \quad-2.172 \times 10^{-2} \quad 9.49$

Solids, residue a $180^{\circ} \mathrm{C}$, dissolved $54 \quad 3.326 \times 10^{-1} \quad 52.3$

$\begin{array}{cc}4.37 & 39 \\ 14.6 & 14 \\ 4.87 & 23 \\ .94 & 19 \\ 21.9 & 12\end{array}$

Tennessee River at mile 592.3 (site T3)

Specific-conductance range $=101$ to 230 microsiemens

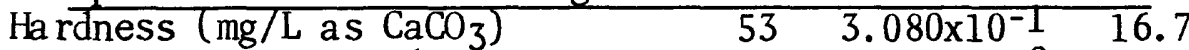

$\begin{array}{llll}\left.\text { Sulfate, dissolved (mg/L as } \mathrm{SO}_{4}\right) & 54 & 4.402 \times 10^{-2} & 2.32\end{array}$

$7.77 \quad 50$

$2.25 \quad 20$

Tennessee River at mile 529.9 (site T19)

Specific-conductance range $=97$ to 230 microsiemens

$\mathrm{pH}$ (standard units) $122 \quad 5.490 \times 10^{-3} 6.50$

Bicarbonate ( $\mathrm{mg} / \mathrm{L}$ as $\left.\mathrm{HOO}_{3}\right)$

$34 \quad 1.308 \times 10^{-1}$

46.8

.43

5.22

12

Carbonate ( $\mathrm{mg} / \mathrm{L}$ as $\left.\mathrm{CO}^{3}\right)$

29

$2.918 \times 10^{-2}$

$-4.63$

.54

39

Ha rdness ( $\mathrm{mg} / \mathrm{L}$ as $\left.\mathrm{CaCO}^{3}\right)$

100

3. $212 \times 10^{-1}$

15.1

Calcium, dissolved (mg/L as Ca) 77

7. $376 \times 10^{-2}$

7.66

6.10

78

Magnesium, dissolved (mg/L as $\mathrm{Mg}$ ) 78

$2.045 \times 10^{-2}$

1.27

1.76

53

Sodium, dissolved (mg/L as $\mathrm{Na}) \quad 78$

6. $399 \times 10^{-2}$

$-4.74$

Potassium, dissolved ( $\mathrm{mg} / \mathrm{L}$ as $\mathrm{K}$ ) 78

$4.047 \times 10^{-3}$

.748

.41

41

Chloride, dissolved (mg/L as C1) 109

Sulfate, dissolved (mg/L as $\left.\mathrm{SO}_{4}\right) 108$

Solids, residue @ $180^{\circ} \mathrm{C}$ dissolved 103

$1.023 \times 10^{-1}$

$-9.93$

4. $330 \times 10^{-2}$

6.14

$5.524 \times 10^{-1}$

7.38

1.11

48

Solids, sum of constituents,

$$
\text { dissolved ( } \mathrm{mg} / \mathrm{L})
$$

63

$4.407 \times 10^{-1}$

18.2

.17

56

18

$2.04 \quad 62$

$2.38 \quad 18$

$9.35 \quad 70$

Clinch River at mile 78.8 (site $\mathrm{C} 1$ )

Specific-conductance range $=160$ to $440 \mathrm{microsiemens}$

Bicarbonate (mg/L as $\mathrm{HCO}_{3}$ ) $393.911 \times 10^{-1} \quad 30$.

Magnesium, dissolved (mg/L as $\mathrm{Mg}$ ) 17

Sulfate, dissolved $\left(\mathrm{mg} / \mathrm{L}\right.$ as $\left.\mathrm{SO}_{4}\right) \quad 49$

$2.337 \times 10^{-2}$

3.38

9.16

46

.65

$2.613 \times 10^{-2}$

11.6

3.28

$4.173 \times 10^{-1}$

42.1

11.3

30

Solids, residue \& $180^{\circ} \mathrm{C}$, dissolved 48

.173x10-1

42.1

Clinch River at 66.3 (site $\mathrm{C} 2$ )

Specific-conductance range $=200$ to $270 \mathrm{microsiemens}$

$\mathrm{Bi}$ carbonate $\left(\mathrm{mg} / \mathrm{L}\right.$ as $\left.\mathrm{HOO}_{3}\right) \quad 27 \quad 2.662 \times 10^{-1} 54$.

$\mathrm{Ni}$ trogen, total $\mathrm{NO}_{2}+\mathrm{NO}_{3}(\mathrm{mg} / \mathrm{L}$ as $\mathrm{N}) 2$

Ha rdness ( $\mathrm{mg} / \mathrm{L}$ as $\mathrm{CaCO}_{3}$ )

$-4.926 \times 10^{-3}$

1.59

2. $778 \times 10^{-2}$

48.6

Magnesium, dissolved (mg/L as $\mathrm{Mg}$ ) 17

5. $334 \times 10^{-2}$

$-3.02$

Sodium, dissolved ( $\mathrm{mg} / \mathrm{L}$ as $\mathrm{Na}$ )

17

$5.334 \times 10^{-2}$
$-1.550 \times 10^{-2}$

6.06

4. $505 \times 10^{-1}$

30.3

$\begin{array}{rr}8.58 & 22 \\ .15 & 26 \\ 11.5 & 9 \\ 1.01 & 29 \\ .30 & 27 \\ 19.2 & 9\end{array}$


Table 14.--Regression statistics describing the relations between specific conductance and several water-quality parameters obtained at main-channel stations at or above Watts Bar Dam during the 1972-82 water years--Continued

\begin{tabular}{ccccc}
\hline Constituent & Number & Standard & Percent \\
& of & Slope & Intercept \\
comparisons & $\mathrm{R}$ & $\begin{array}{c}\text { error of explained } \\
\text { estimate }\end{array}$ & $\begin{array}{c}\text { expriance } \\
\text { variance }\end{array}$ \\
\hline
\end{tabular}

Clinch River at mile 48.6 (site $\mathrm{C} 7$ )

Specific-conductance range $=94$ to 130 microsiemens

$\begin{array}{lcccrr}\text { Bicarbonate (mg/L as } \mathrm{HCO}_{3} \text { ) } & 24 & 4.949 \times 10^{-1} & 7.47 & 8.06 & 78 \\ \text { Phosphorus, total (mg/L as P) } & 63 & -7.017 \times 10^{-4} & .184 & .03 & 21 \\ \text { Hardness (mg/L as CaCO3) } & 55 & 2.729 \times 10^{-1} & 47.6 & 15.7 & 16 \\ \text { Magnesium, dissolved (mg/L as Mg) } & 17 & 5.044 \times 10^{-2} & -2.34 & .86 & 43 \\ \text { Chloride, dissolved (mg/L as C1) } & 67 & 5.746 \times 10^{-3} & 2.00 & .86 & 4 \\ \text { Solids, residue a } 180^{\circ} \mathrm{C} \text {, dissolved } 79 & 3.481 \times 10^{-1} & 53.1 & 14.6 & 30 \\ \text { Solids, sum of constituents, } & 17 & 2.447 \times 10^{-1} & 72.9 & 6.98 & 21\end{array}$

dissolved $(\mathrm{mg} / \mathrm{L})$

Clinch River at mile 23.1 (site $\mathrm{Cl3}$ )

Specific-conductance range $=156$ to $290 \mathrm{microsiemens}$

Bicarbonate (mg/L as $\mathrm{HOO}_{3}$ ) 10

Phosphorus, total (mg/L as P) 85

$\mathrm{Hardness}\left(\mathrm{mg} / \mathrm{L}\right.$ as $\left.\mathrm{CaCO}_{3}\right)$

$\begin{array}{lll}10 & 7.890 \times 10^{-1} & -61.9\end{array}$

$85 \quad 9.299 \times 10^{-4} \quad-.184$

$8.56 \quad 80$

$55 \quad 2.935 \times 10^{-1}$

42.1

Magnesium

$30 \quad 7.820 \times 10^{-2}$

13.1

$3.636 \times 10^{-2}$

.014

Potassium, dissolved ( $\mathrm{mg} / \mathrm{L}$ as K) 30

Sulfate, dissolved ( $\mathrm{mg} / \mathrm{L}$ as $\left.\mathrm{SO}_{4}\right) \quad 80$

Silica, dissolved ( $\mathrm{mg} / \mathrm{L}$ as $\left.\mathrm{SiO}_{2}\right) \quad 54$

Solids, Residue a $180^{\circ} \mathrm{C}$, dissolved 76

Solids, sum of constituents, $\quad 30$

2. $352 \times 10^{-3}$

.843

$8.567 \times 10^{-2}$

$-3.23$

$-2.007 \times 10^{-2}$

8.70

$5.483 \times 10^{-1}$

7.27

$3.906 \times 10^{-1}$

37.7

.10

4

11.0

31

$1.54 \quad 70$

$.61 \quad 76$

.20

11

$3.35 \quad 27$

$1.16 \quad 16$

$17.7 \quad 33$ dissolved (mg/L)

$5.72 \quad 81$

Emory River at mile 18.3 (site E1) Specific-conductance range $=156$ to 290 microsiemens

Streamflow, instataneous ( $\left.\mathrm{ft}^{3} / \mathrm{s}\right) \quad 103 \quad-2.102 \times 10 \quad 3100$

pH (standard units)

Bicarbonate ( $\mathrm{mg} / \mathrm{L}$ as $\left.\mathrm{HOO}_{3}\right)$

$\mathrm{Nitrogen}$, total $\mathrm{NO}_{2}+\mathrm{NO}_{3}$

$75 \quad 6.962 \times 10^{-3}$

6.18

1921

$10 \quad 1.884 \times 10^{-1}$

1.28

$54-1.095 \times 10^{-3}$

.229 (mg/L as $\mathrm{N}$ )

Hardness ( $\mathrm{mg} / \mathrm{L}$ as $\left.\mathrm{CaCO}_{3}\right)$

Chloride, dissolved ( $\mathrm{mg} / \mathrm{L}$ as $\mathrm{Cl}$ )

$39 \quad 3.313 \times 10^{-1}$

2.18

50

1. $226 \times 10^{-2}$

2.50

Sulfate, dissolved ( $\mathrm{mg} / \mathrm{L}$ as $\mathrm{SO}_{4}$ )

71

2. $429 \times 10^{-1}$

$-1.91$

$-1.548 \times 10^{-2}$

4.19

$5.469 \times 10^{-1} \quad 7.48$

.58

2.82

.07

18

Silica, dissolved $\left(\mathrm{mg} / \mathrm{L}\right.$ as $\left.\mathrm{SiO}_{2}\right) \quad 24$

$5.14 \quad 84$

$1.29 \quad 10$

$5.12 \quad 83$

$.89 \quad 28$

$11.1 \quad 84$

Emory River at mile 14.9 (site E2)

Specific-conductance range $=18$ to 360 microsiemens

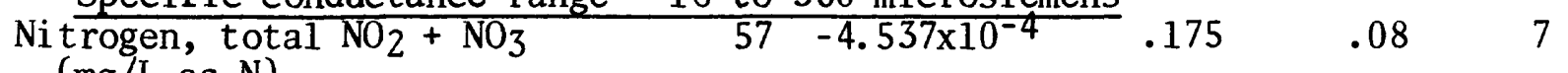
(mg/L as $\mathrm{N}$ )

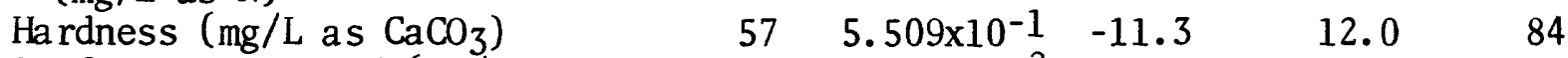

Sulfate, dissolved (mg/L as $\mathrm{SO}_{4} \quad \begin{array}{rrrrr}58 & 6.599 \times 10^{-2} & 8.05 & 3.90 & 42\end{array}$ 


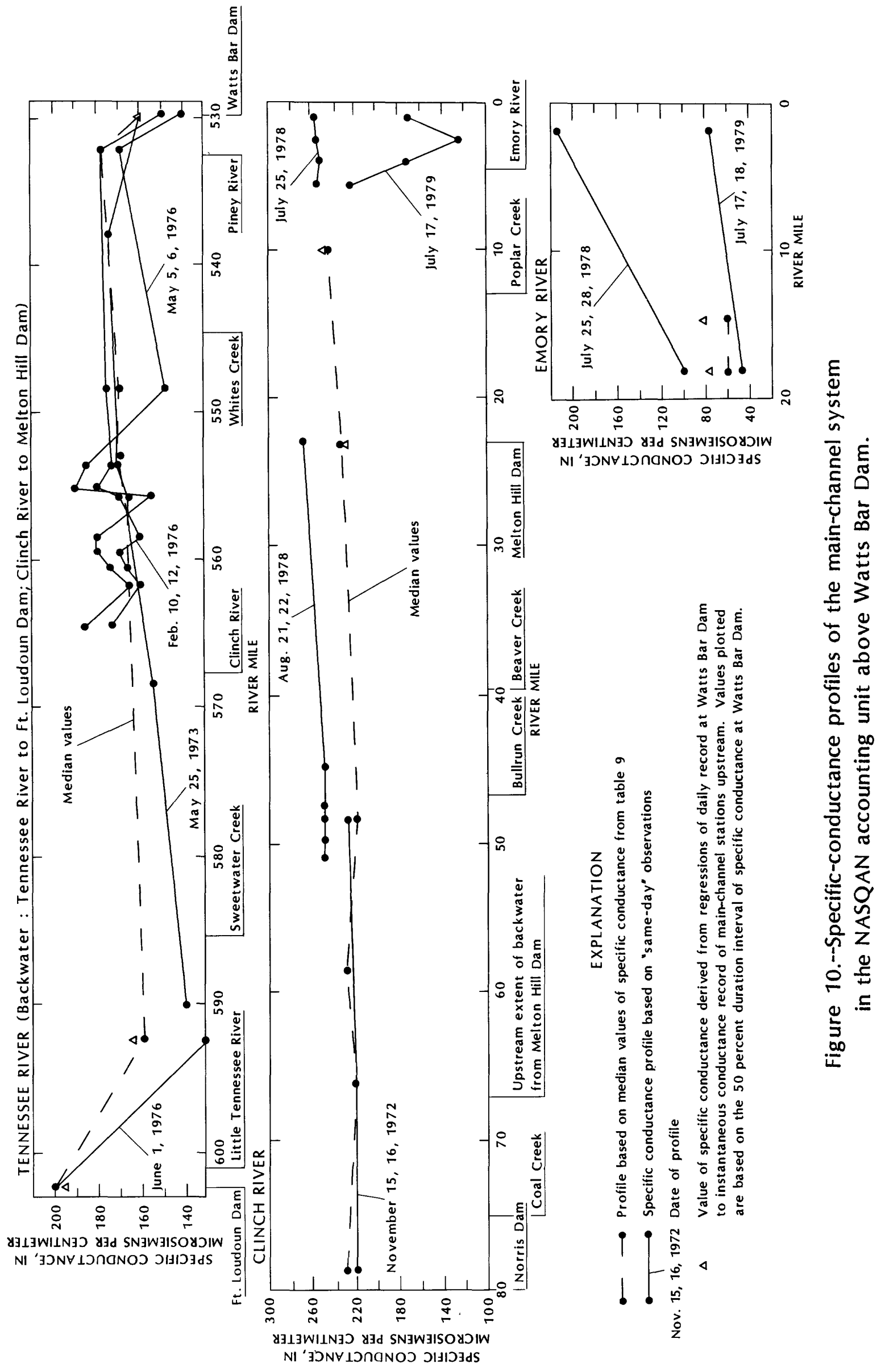


The daily mean values of specific conductance at the Watts Bar NASQAN station were regressed against the instantaneous observations of specific conductance made the same day at other main-channel stations (table 15). Sufficient concurrent data were not available for regressions based on the daily conductance record of the Melton Hill NASQAN station. The regression relations presented in table 15 were used to estimate the specific conductance at other main-channel stations that correspond to the 50 percent duration interval (median) value of the Watts Bar daily conductance record. These estimated median values compare favorably with the medians of observed conductance values and are plotted on figure 10. It is considered that through specific conductance relations the NASQAN station is able to represent the water-quality of the main-channel system of the accounting unit. The specific-conductance profile of estimated median values were used with the regression statistics presented in table 14 to generate the estimated median values of selected constituents presented in table 9.

$$
\text { Hydrogen-ion activity }(\mathrm{pH})
$$

The most acidic waters of the study area (minimum $\mathrm{pH}$ values, table 8 ) come frorn subbasins in which known mining activities have occurred.

No significant $\mathrm{pH}$ trends were indicated from data of the $\mathrm{Clinch} \mathrm{River}$ and Tennessee River stations, however an increasing $\mathrm{pH}$ trend was indicated on the Emory River at mile 18.3 (table 11). This trend for the Emory River, which drains an area of extensive coal mining, may be in part due to reduced acid-mine runoff since implementation of the Surface Mining Control and Reclamation Act of 1977 (Public Law 95-87). The Act specifies that the $\mathrm{pH}$ of mine effluents must be between 6.0 and 9.0 units. It is not surprising that this increasing $\mathrm{pH}$ trend is not reflected at the NASQAN station at Watts Bar because the Emory River basin is only 5 percent of the drainage area.

Table 15.--Regression statistics describing the relations between daily specific conductance obtained at the Watts Bar NASQAN station and instantaneous specific-conductance observations obtained at main channel stations above Watts Bar Dam

\begin{tabular}{|c|c|c|c|c|c|c|}
\hline $\begin{array}{l}\text { Site } \\
\text { No. }\end{array}$ & Station & $\begin{array}{c}\text { Number } \\
\text { of } \\
\text { comparisons }\end{array}$ & $\begin{array}{c}\text { Slope } \\
\mathrm{R}\end{array}$ & $\begin{array}{c}\text { Intercept } \\
\cdot \mathrm{B} \\
\end{array}$ & $\begin{array}{l}\text { Standard } \\
\text { error of } \\
\text { estimate }\end{array}$ & $\begin{array}{l}\text { Percent } \\
\text { explained } \\
\text { variance }\end{array}$ \\
\hline $\mathrm{T} 1$ & $\begin{array}{l}\text { Tennessee River } \\
\text { at mile } 602.3 \text {. }\end{array}$ & 27 & 0.7832 & 69.7 & 20.0 & 37 \\
\hline $\mathrm{T} 2$ & $\begin{array}{l}\text { Tennessee River } \\
\text { at mile } 593.3 .\end{array}$ & 46 & .5357 & 78.0 & 22.0 & 18 \\
\hline C13 & $\begin{array}{l}\mathrm{Cl} \text { inch River } \\
\text { at mile } 23.1 .\end{array}$ & 44 & . 4989 & 153 & 25.1 & 14 \\
\hline $\mathrm{Cl} 4$ & $\begin{array}{l}\mathrm{Cl} \text { inch River } \\
\text { at mile } 10.0 .\end{array}$ & 39 & . 6997 & 136 & 31.0 & 19 \\
\hline $\mathrm{El}$ & $\begin{array}{l}\text { Emory River } \\
\text { at mile } 18.3 .\end{array}$ & 72 & .6201 & -22.7 & 35.5 & 11 \\
\hline E2 & $\begin{array}{l}\text { Emory River } \\
\text { at mile } 14.9 .\end{array}$ & 46 & 1.214 & -114 & 48.8 & 19 \\
\hline
\end{tabular}




\section{Sulfate}

Median values of dissolved sulfate obtained at stations in the sub-basins of the study area during the 1972-82 water years are presented in table 7. As might be expected, the highest dissolved sulfate values were obtained on streams that drain coal-mining areas of the Cumberland Plateau (CA $384 \mathrm{mg} / \mathrm{L}$ and ER $472 \mathrm{mg} / \mathrm{L}$ ).

In general, dissolved sulfate concentrations showed an increasing trend in the Clinch and Emory River basins during the 1972-82 water years (table 11). These rivers drain areas in which coal-mining is prevalent. No increasing trend in dissolved sulfate was indicated on the Tennessee River above its confluence with the Clinch River, but below the confluence, a slightly increasing trend was indicated.

No significant trend in dissolved sulfate was indicated on the Tennessee River at mile 602.3, but a decreasing trend was indicated at mile 592.3. The major inflow between Tennessee River miles 602.3 and 592.3 is from the Little Tennessee River. An increasing trend in sulfate was indicated on the Clinch River at miles 78.8, 48.6, and 23.1 (Melton Hill), but no significant trend was indicated at mile 66.3. Fewer determinations of dissolved sulfate were obtained at Clinch River mile 66.3 than at the other locations which may be the reason for this inconsistency. No significant trend was indicated on the Clinch River at mile 10.0 which is affected by backwater from Watts Bar Reservoir. An increasing trend in dissolved sulfate was indicated on the Emory River at mile 18.3 but not at mile 14.9. This inconsistency cannot be fully explained, but it should be noted that a trend test of flow-adjusted concentrations performed on Emory River at mile 18.3 data indicates a lesser increasing trend than the unadjusted trend test. A slightly increasing trend in dissolved sulfate was indicated at the outlet of the study area at Watts Bar Dam.

\section{Trace Constituents}

Concentrations of a variety of constituents occur naturally in surface waters in trace amounts only. Certain trace constituents such as arsenic, cadmium, lead, and mercury can be highly toxic to both humans and wildlife. Other constituents, such as copper and zinc, are believed to be essential to life. Some trace constituents, such as iron and manganese, may cause undesirable water taste, or may cause industrial problems such as scaling in pipes and boilers.

Several different analytical procedures with different levels of detection were used to determine trace constituent data during the 1972-82 water years. Differing, detection levels and accuracies can be attributed to both laboratory procedure inconsistencies of the various data collection agencies and improvements of analytical techniques during the period. To reduce the possibility of detecting false trends, the following procedure was used:

(1) The least sensitive detection limit of all the analytical procedures used for each constituent at each station was determined.

(2) All values reported as less than the least sensitive detection limit were set to one-half the value of the detection limit.

The Seasonal Kendall test was applied only to data from the main-channel stations due to a lack of trace constituent data in most of the sub-basins. The test, which was performed on a quarterly seasonal basis, showed no significant trends except for the following:

Total recoverable copper on the Clinch $\mathrm{River}$ at mile 48.6, indicated a decreasing trend estimate of $10 \mu \mathrm{g} / \mathrm{L}$ per year.

- Total recoverable manganese on the Clinch River at mile 48.6, indicated a decreasing trend of about $12 \mu \mathrm{g} / \mathrm{L}$ per year.

- Total recoverable manganese on the Clinch River at mile 23.1, indicated a decreasing trend estimate of $2 \mu \mathrm{g} / \mathrm{L}$ per year.

\section{Mercury}

Very few natural waters contain readily detectable concentrations of mercury (Hem, 1970). Concentrations of mercury in unpolluted rivers in areas where no natural mercury deposits are 
known is generally less than $0.1 \mu \mathrm{g} / \mathrm{L}$ (Wershaw, 1970). The national drinking-water regulations recommend a limit of $2 \mu \mathrm{g} / \mathrm{L}$ dissolved mercury for domestic water supply.

An estimated 2.4 million pounds of mercury were lost or otherwise unaccounted for from the Oak Ridge National Laboratory between 1950 and 1977 , with an estimated 475,000 pounds discharged to streams in the Poplar Creek basin (TVA, 1983). This mercury entered the stream system at the headwaters of East Fork Poplar Creek, which flows into Poplar Creek at mile 5.5, and then into the Clinch River at mile 12.

The maximum value of total recoverable mercury determined 1972-82 in water obtained at the Watts Bar NASQAN station (below the mercury spill) or at the Melton Hill NASQAN station (above the mercury spill) did not exceed $0.5 \mu \mathrm{g} / \mathrm{L}$.

\section{Iron}

The maximum values of total recoverable iron in sub-basins of the study area (table 8) are highest in basins where coal mining is known to have occurred. However, comparison of median total recoverable iron values obtained at stations in the sub-basins (table 7) to land-use information (fig. 4) shows high iron values in some streams draining areas in which no mining activities have been documented. Notably, a median value of $1,300 \mu \mathrm{g} / \mathrm{L}$ was obtained on Beaver Creek which drains a predominately urban area.

Total recoverable iron data indicate decreasing trends at stations on the Tennessee River at miles 602.3, 593.3, and 529.9 (Watts Bar) (table 11). Total recoverable iron also shows a decreasing trend or no significant trend near the mouths of the Clinch and Emory Rivers. However, increasing trends in iron concentrations are indicated on the Clinch River from mile 78.8 to 48.6 . Between Clinch River miles 48.6 and 23.1 (Melton Hill) the indicated trend reverses. It is probable that iron adsorption to sediment that settles-out in the reservoir above Melton Hill Dam may be the reason that the total recoverable iron increasing trend is not observed below the reservoir.

\section{Nutrients}

Nitrogen

Median values of total nitrite plus nitrate nitrogen $\left(\mathrm{NO}_{2}+\mathrm{NO}_{3} \mathrm{mg} / \mathrm{L}\right.$ as $\left.\mathrm{N}\right)$ obtained at stations in the sub-basins of the study area during the 1972-82 water years are presented in table 7 . Although not conclusive, comparisons of median total nitrite plus nitrate-nitrogen values obtained at sub-basin stations to wastewater discharge sites (fig. 8) suggest that stations downstream of known wastewater discharge sites have higher nitrogen values than stations above known wastewater discharges.

Trend test results for main-channel station nitrogen data are given in table 11 . An increasing trend in total nitrite plus nitrate nitrogen is indicated on the Clinch River at mile 78.8 and mile 48.6, however no significant trend is indicated below Melton Hill Dam at Clinch River mile 23.1. No significant trends are indicated on the Tennessee River at mile 602.3 and mile 593.3, but a slight decreasing trend in nitrogen is indicated below Watts Bar Dam at Tennessee River mile 529.9. Station data for the Emory River, which flows into Watts Bar Reservoir, indicates no significant trend at mile 18.3 but an increasing trend in total nitrite plus nitrate nitrogen at mile 14.9 .

\section{Phosphorus}

In general, a desirable guideline for allowable limits of total phosphorus is $0.1 \mathrm{mg} / \mathrm{L}$ for rivers, and $0.05 \mathrm{mg} / \mathrm{L}$ where streams enter lakes or reservoirs (National Technical Advisory Committee, 1968). The median values of total phosphorus for main-channel stations in the study area are generally within the recommended limit for streams entering reservoirs (table 9). However, the maximum total phosphorus values obtained at many of these main-channel stations exceeded the recommended limit.

No significant total phosphorus trends were indicated on the Clinch River from mile 78.8 to mile 10.0. A slightly increasing trend in total phosphorus was indicated on the Tennessee River at mile 602.3, and a slightly decreasing trend was indicated at mile 592.3. Most of the samples 
collected at Tennessee River mile 602.3 did not include the flow of the Little Tennessee River which may account for the difference in trends at these two locations. No significant trend in total phosphorus was indicated on the Emory River at mile 18.3, however a decreasing trend was indicated on the Emory River at mile 14.9 where a greater number of samples were obtained. No significant trend in total phosphorus was indicated at Watts Bar Dam, the discharge end of the study area.

\section{Organics and Biological}

Fecal coliform bacteria

The maximum values of fecal coliform bacteria obtained in the Bullrun Creek, Obed River, and Emory River sub-basins ranged from 630 to 1,200 colonies per $100 \mathrm{~mL}$ (table 8). However, insufficient data were available on an area-wide basis to determine the possible sources. The maximum value of fecal coliform bacteria obtained on the Tennessee River at mile 593.3 was 13,000 colonies per $100 \mathrm{~mL}$ (table 9). According to the Knoxville News-Sentinel (May 20, 1983), raw sewage has occasionally bypassed treatment plants and entered Fort Loudoun Lake above the study area. Samples taken from one tributary to Fort Loudoun Lake showed a fecal coliform bacteria count of 81,000 colonies per $100 \mathrm{~mL}$. The report also states that during wet weather 5 to 10 million gallons of raw sewage bypasses the treatment plant daily. No other main-channel station of the study area had unusually high fecal coliform values, however, data were very limited.

\section{Organic Carbon}

No significant trends in total organic carbon were indicated at main-channel stations except on the Tennessee River at mile 592.3 (table 11).

\section{Sediment}

According to a sediment study by Trimble and Carey (1984), the Tennessee River and Clinch River Reservoirs in the study area act as sediment traps. Sediment yield, accumulation, and outflow of reservoirs in the study areas as computed by Trimble and Carey are given in table 16.

Table 16.-- Sediment yield, accumulation, and outflow of Norris, Melton Hi11, Fort Loudoun, and Watts Bar Reservoirs

[a, Average yield of contributing drainage a rea between reservoirs. Watts Bar calculations include the drainage area of the Little Tennessee River and the Fort Loudoun calculations do not; from Trimble and Carey, 1984]

\begin{tabular}{|c|c|c|c|c|c|c|c|c|}
\hline Reservoir & $\begin{array}{c}\text { Bulk } \\
\text { density } \\
\left(1 \mathrm{~b} / \mathrm{ft}^{3}\right)\end{array}$ & $\begin{array}{c}\text { Local } \\
\text { sediment } \\
\text { yielda } \\
{\left[\left(\text { ton } / \mathrm{mi}^{2}\right) / y r\right]}\end{array}$ & $\begin{array}{l}\text { Sediment } \\
\text { outflow } \\
\text { (tons/yr) }\end{array}$ & $\begin{array}{l}\text { Sediment } \\
\text { accumu- } \\
\text { lation } \\
\text { (tons/yr) }\end{array}$ & $\begin{array}{c}\text { Trap } \\
\text { efficiency } \\
\text { (Brune } \\
\text { percent) }\end{array}$ & $\begin{array}{l}\text { Local trap } \\
\text { efficiency } \\
\text { (Churchill } \\
\text { percent) }\end{array}$ & $\begin{array}{l}\text { Outflow trap } \\
\text { efficiency } \\
\text { (Churchill } \\
\text { percent) }\end{array}$ & $\begin{array}{l}\text { Outflow } \\
\text { routed } \\
\text { to: }\end{array}$ \\
\hline Norris & 55 & 310 & 0 & 884,000 & 100 & 100 & 95 & Melton $\mathrm{Hi} 11$ \\
\hline Melton Hill & 55 & 150 & 9,700 & 56,000 & 75 & 85 & 60 & Watts Bar \\
\hline Fort Loudoun & 50 & 490 & 160,000 & 620,000 & 75 & 80 & 50 & Watts Bar \\
\hline Watts Bar & 55 & 630 & 343,000 & $1,650,000$ & 80 & 85 & 60 & \\
\hline
\end{tabular}




\section{Suspended sediment}

The maximum known values of suspended sediment in sub-basins of the study area range from $17 \mathrm{mg} / \mathrm{L}$ in the Clear Creek basin where little or no coal mining has occurred, to $2,170 \mathrm{mg} / \mathrm{L}$ in the Clinch River basin above Bullrun Creek where mining is prevalent (table 8). Maximum known values of suspended sediment below Watts Bar Dam and Melton Hill Dam are only $43 \mathrm{mg} / \mathrm{L}$ and $19 \mathrm{mg} / \mathrm{L}$, respectively.

Suspended-sediment data unadjusted for the effects of flow indicate decreasing trends at Watts Bar, Melton Hill, and the Emory River at mile 18.3 (table 11). However, the trend test of flow adjusted concentrations of the Emory River at mile 18.3 showed no significant trend. This probably indicates that the decreasing sediment trends of unadjusted concentrations reflect the decreasing flow trend of the study area during the 1972-82 water years.

\section{Bed material}

Small particle-size bed material is virtually nonexistent in the channel reaches below Watts Bar Dam and Melton Hill Dam where water-quality sampling for NASQAN is conducted. This is probably due to high flow energies during dam operations. Available data for constituents in bed material are summarized in table 17 and show that concentrations of mercury, chromium, copper, lead, and nickel in East Fork Poplar Creek, Poplar Creek, and the Clinch River are generally above background concentrations (TVA, 1983).

Table 17.-- Mean concentrations of trace constituents in bed material samples obtained from streams above Watts Bar Dam during the period 1970-83

[Values in microgram per gram dry weight]

Location Mercury Cadmium Chromium Copper Lead Nickel Zinc Aluminum Beryllium Manganese

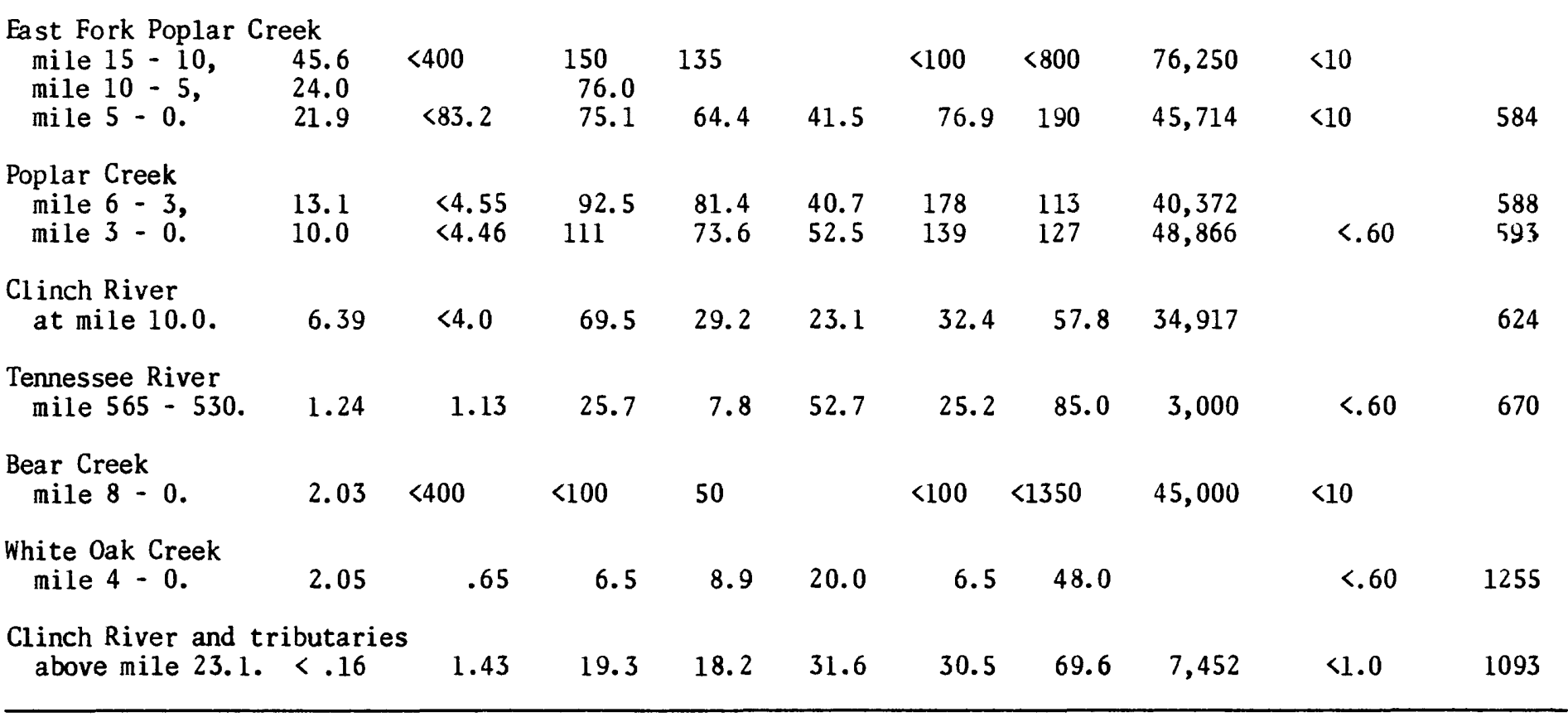

Compilation by the Tennessee Valley Authority. 


\section{WATER TEMPERATURE}

Measurements of continuous water temperatures were obtained at the two NASQAN stations in the study area. Daily average water temperatures were analyzed using a statistical technique of Steele (1974) to fit the data to a harmonic (sinusoidal) equation. The harmonic expression used to represent daily temperature has the form:

$$
T^{\prime}(D)=M+A \sin [0.0172 \times(D)+C]
$$

where

$T^{\prime}(D)$ is estimated temperature on the Dth day, in ${ }^{\circ} \mathrm{C}$;

$D$ is a day of the year (October 1 , the beginning of the water year, is represented by integer 1);

$M$ is the harmonic mean temperature, in ${ }^{\circ} \mathrm{C}$;

$A$ is the harmonic amplitude of the stream temperature curve, in ${ }^{\circ} \mathrm{C}$; and

$\mathrm{C}$ is the phase angle, in radians.

The harmonic coefficients ( $M, A$, and $C)$, the standard error of estimate of a daily temperature value in ${ }^{\circ} \mathrm{C}$, and the percentage of the variation in daily temperature values that is accounted for by the harmonic function are shown in table 18. Standard errors of estimate of stream temperature at the two NASQAN stations were less than $2^{\circ} \mathrm{C}$, and the explained variations were 85 percent or greater. Comparisons of estimated water temperatures from the harmonic analyses to average observed water temperatures at Watts Bar and Melton Hill are shown in figure 11.

\section{LOAD COMPUTATIONS}

As stated previously, the relation between water-quality constituents and discharge are not well defined on the Clinch and Tennessee Rivers due to regulation. However, relations of specific conductance to other water-quality parameters were evaluated, and continuous specific-conductance and discharge records were available at the NASQAN stations. This information was used to estimate constituent loads of the two NASQAN stations presented in table 19 by the following procedure:

- Constituent to specific-conductance linear regressions were computed (table 14).

- Duration tables of daily specific conductance were compiled from the NASQAN station records (table 5 ).

- Duration tables of other constituents were computed from the specific-conductance duration tables by use of constituent to specificconductance regressions. A weighted mean concentration was estimated from the constituent duration tables.

- These average yearly constituent concentrations were then multiplied by the average discharge of the station (table 2) to give an estimate of yearly constituent loads.

Constituent load estimates for other main-channel stations were not possible using this method because continuous specific-conductance records were not available. Also, sufficient data were not available for estimates of sub-basin constituent loads.

Table 18.--Harmonic analyses of stream temperature records of Melton Hill. Dam and Watts Bar Dam

[Form of equation: $T^{\prime} D=M+A \times \sin (0.0172 \times D+C)$ ]

\begin{tabular}{lrrrrrrr}
\hline $\begin{array}{l}\text { Site } \\
\text { No. }\end{array}$ & Station & $\begin{array}{c}\text { Sample } \\
\text { size }\end{array}$ & $\begin{array}{c}\text { Harmonic } \\
\text { mean } \\
\left.\text { ( }{ }^{\circ} \mathrm{C}\right)\end{array}$ & $\begin{array}{c}\text { Amplitude } \\
\text { A } \\
\left({ }^{\circ} \mathrm{C}\right)\end{array}$ & $\begin{array}{c}\text { Phase } \\
\text { angle-C } \\
\text { radians })\end{array}$ & $\begin{array}{c}\text { Variation } \\
\text { explained } \\
\text { (percent })\end{array}$ & $\begin{array}{c}\text { Standard } \\
\text { error } \\
\left({ }^{\circ} \mathrm{C}\right)\end{array}$ \\
\hline $\mathrm{C} 13$ & Melton Hi11 & 547 & 14.50 & 6.44 & 2.60 & 85 & 1.84 \\
T19 & Watts Bar & 1808 & 16.29 & 10.29 & 2.52 & 95 & 1.59 \\
\hline
\end{tabular}




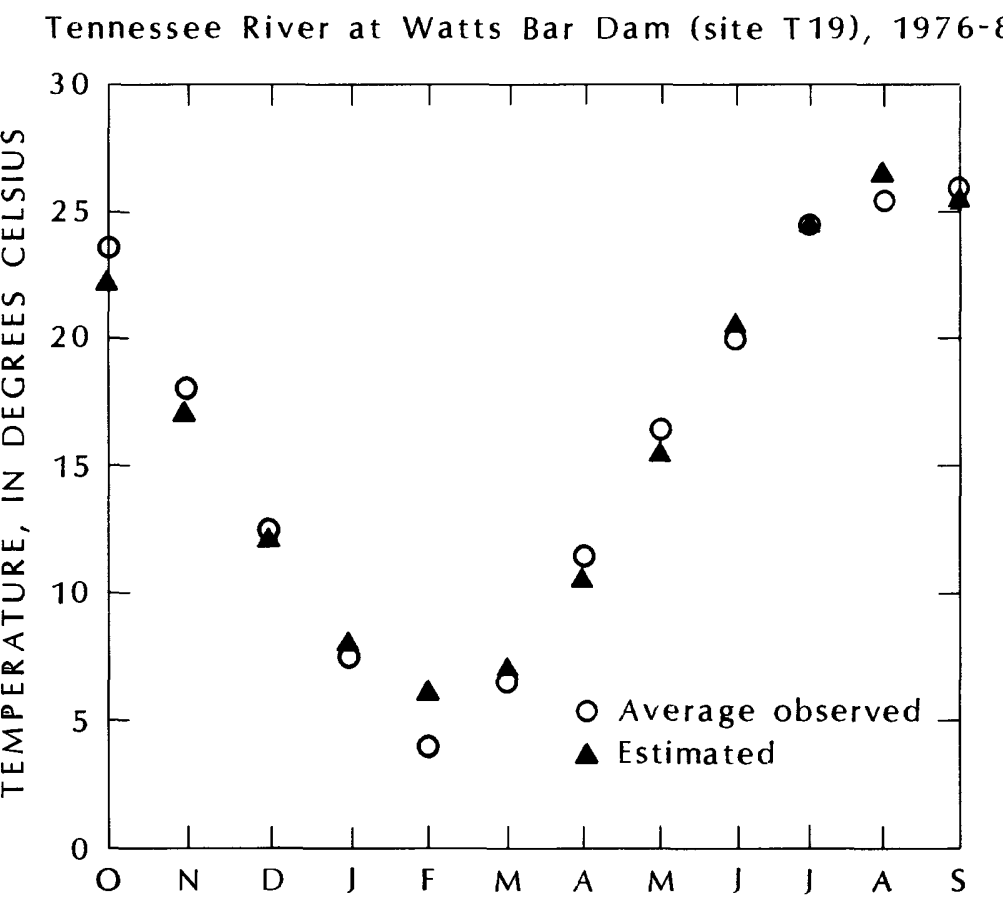

Clinch River at Melton Hill Dam (site C13), 1981-82

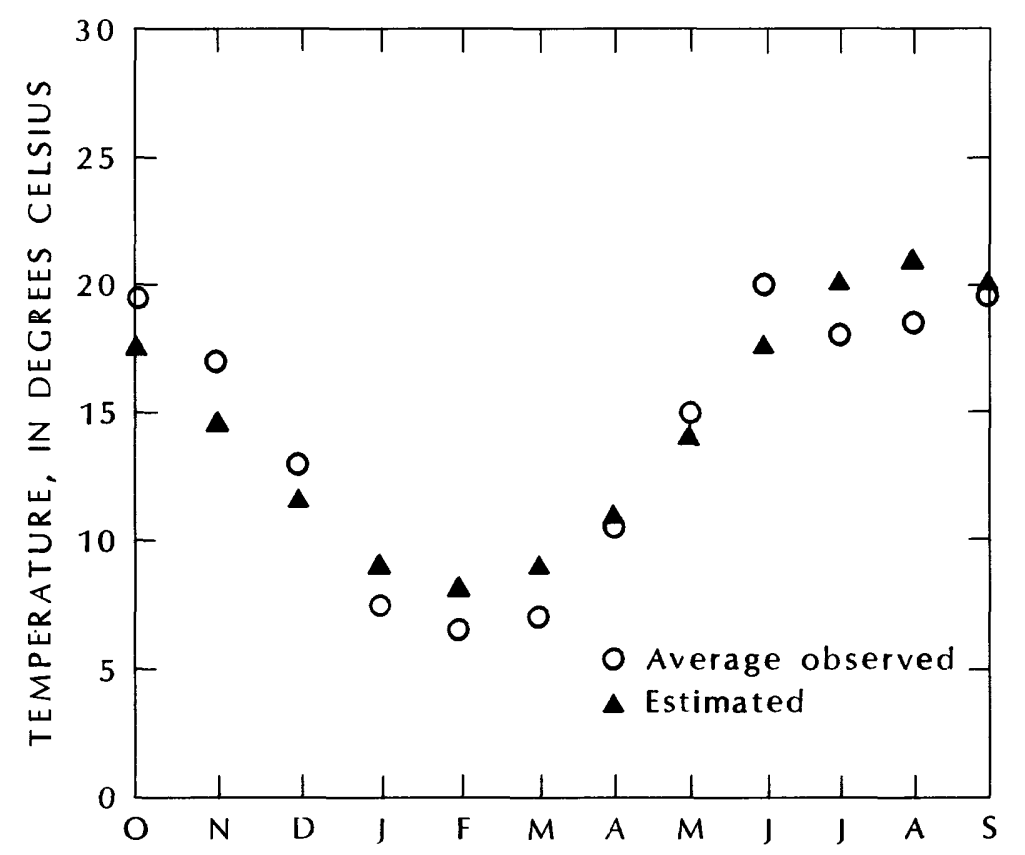

Figure 11.--Comparison of estimated water temperatures from harmonic analyses to the average observed water temperatures at the Watts Bar and Melton Hill NASQAN stations. [Form of equation: $T^{\prime} D=M+A \sin (0.0172 \times D+C)$ ] 
Table 19.--Load estimates of selected constituents sampled at the Watts Bar and Melton Hill NASQAN stations

\begin{tabular}{ccc}
\hline Constituent & $\begin{array}{c}\text { Weighted mean } \\
\text { concent ration estimate } \\
(\mathrm{mg} / \mathrm{L})\end{array}$ & $\begin{array}{c}\text { Load } \\
\text { estimate } \\
\left.\text { (tons } / \mathrm{yr}^{\mathrm{r}}\right)\end{array}$ \\
\hline
\end{tabular}

$\underline{\text { Tennessee River at Watts Bar Dam (site T19) }}$

$\begin{array}{lcr}\text { Solids, residue at } 180^{\circ} \mathrm{C} \text {, dissolved } & 99 & 2,800,000 \\ \text { Solids, sum of constituents, dissolved } & 90 & 2,550,000 \\ \text { Calcium, dissolved } & 20 & 566,000 \\ \text { Magnesium, dissolved } & 4.6 & 130,000 \\ \text { Sodium, dissolved } & 5.7 & 161,000 \\ \text { Sulfate, dissolved } & 13 & 368,000 \\ \text { Chloride, dissolved } & 6.7 & 190,000 \\ \text { Bicarbonate } & 68 & 1,930,000\end{array}$

Clinch River at Melton Hil1 Dam (site C13)

$\begin{array}{lcr}\text { Solids, residue at } 180^{\circ} \mathrm{C} \text {, dissolved } & 145 & 664,000 \\ \text { Solids, sum of constituents, dissolved } & 135 & 618,000 \\ \text { Calcium, dissolved } & 33 & 151,000 \\ \text { Magnesium, dissolved } & 9.1 & 42,000 \\ \text { Sulfate, dissolved } & 18 & 82,000 \\ \text { Bicarbonate } & 135 & 618,000 \\ \text { Silica, dissolved } & 3.7 & 17,000\end{array}$

\section{RESER VOIR STRATIFICATION}

Significant water-quality differences can occur between the surface, mid-depth, and bottom of a lake or reservoir. Water released from an impoundment from one vertical position therefore may not be fully representative of the upstream impoundment. The river profile of specific conductance presented in figure 10 indicates that specific conductance is higher upstream of Watts Bar Dam than downstream. Additional same-day data show higher specific-conductance values upstream of Watts Bar Dam than downstream of the dam (table 20). Values of $\mathrm{pH}$ obtained above Watts Bar Dam are also generally higher than those obtained below the dam, however neither total phosphorus nor total nitrite plus nitrate nitrogen data showed discernible differences above or below Watts Bar Dam.
Flow through the power-generation turbines accounted for more than 95 percent of the dam releases for the dates of sample collection listed in table 20. The normal minimum operating level of Watts Bar Reservoir is at an elevation of 735 feet. There are five turbine intakes with three bays each. Each bay opening is 21.08 feet wide by 47.46 feet high, with the top of the intake located at an elevation of 712.5 feet. The center line of the turbine distributor is at an elevation of 676 feet. Design of the turbine intakes may result in releases from stratified layers of the impoundment; therefore, further study is needed to determine whether the NASQAN data obtained below Watts Bar Dam is representative of the water quality of Watts Bar Reservoir. No data were available both above and below Melton Hill Dam for comparison. 
Table 20. - Water-quality parameters obtained the same day above and below Watts Bar Dam (sites T17 and T19)

\begin{tabular}{|c|c|c|c|c|c|c|c|c|}
\hline \multirow[t]{2}{*}{ Date } & \multirow{2}{*}{\multicolumn{2}{|c|}{$\begin{array}{c}\text { Specific } \\
\text { conductance } \\
\text { above below }\end{array}$}} & \multicolumn{2}{|c|}{$\mathrm{pH}$} & \multicolumn{2}{|c|}{$\begin{array}{c}\text { Total } \\
\text { phosphorus } \\
\text { (mg/L as P) }\end{array}$} & \multicolumn{2}{|c|}{$\begin{array}{c}\text { Total } \\
\mathrm{NO}_{2}+\mathrm{NO}_{3} \\
\text { nitrogen } \\
(\mathrm{mg} / \mathrm{L} \text { as } \mathrm{N})\end{array}$} \\
\hline & & & above & below & above & below & above & below \\
\hline $\begin{array}{r}5-19-75 \\
2-12-76 \\
5-5-76 \\
8-4-76 \\
11-4-76 \\
2-9-77 \\
5-3-77 \\
8-2-77 \\
11-8-77\end{array}$ & $\begin{array}{l}154 \\
178 \\
169 \\
159 \\
178 \\
193 \\
154 \\
183 \\
180\end{array}$ & $\begin{array}{l}150 \\
150 \\
141 \\
150 \\
177 \\
180 \\
140 \\
162 \\
180\end{array}$ & $\begin{array}{l}7.5 \\
7.5 \\
7.8 \\
7.6 \\
7.4 \\
7.9 \\
7.5 \\
7.7 \\
7.3\end{array}$ & $\begin{array}{l}7.4 \\
7.5 \\
7.5 \\
7.2 \\
7.4 \\
7.8 \\
6.5 \\
7.5 \\
7.4\end{array}$ & $\begin{array}{r}0.040 \\
.020 \\
.023 \\
.023 \\
.017 \\
.023 \\
.020 \\
.043\end{array}$ & $\begin{array}{r}0.040 \\
.020 \\
.030 \\
.024 \\
.020 \\
.020 \\
.027 \\
.025\end{array}$ & $\begin{array}{r}0.55 \\
.21 \\
.21 \\
.29 \\
.47 \\
.36 \\
.15 \\
.38\end{array}$ & $\begin{array}{r}0.53 \\
.21 \\
.29 \\
.31 \\
.42 \\
.37 \\
.25 \\
.35\end{array}$ \\
\hline
\end{tabular}

\section{ANALYSIS OF TREND PROCEDURES}

The major problem with the use of trend procedures for this study was the lack of a means to perform flow adjustments. Identification of trends caused by process (source) change was therefore not possible on the Clinch and Tennessee Rivers. The fact that flow itself indicated a decreasing trend throughout the study area compounded this problem. Thus indicated trends in concentrations of chemical constituents may be reflections of the trends in discharge rather than of source changes.

The Seasonal Kendall test provides a single summary statistic for the available record. Comparison of constituent trends from two or more stations along a channel should be restricted to periods of concurrent record because trends in opposing directions outside of the concurrent record period could result in inconsistent trend indications. For example, an increasing trend in specific conductance is indicated at Emory River mile 18.3 but no significant trend is indicated at mile 14.9. No major inflows occur between these sites and both locations are above backwater from Watts Bar Reservoir. The reason for this inconsistency was judged to be differences in completeness of the record and some nonconcurrent record periods. Trends of data from Emory River miles 18.3 and 14.9 are not in agreement for several of the other constituent tests [total phosphorus, total nitrite plus nitrate nitrogen, total recoverable iron, and dissolved sulfate].

\section{SUMMARY AND CONCLUSIONS}

The Clinch, Emory, and Tennessee Rivers compose the main-channel systems of the study area. The Clinch and Tennessee Rivers are highly regulated by flood-control and power-generation control structures. Two NASQAN stations are located in the study area; one is below Watts Bar Dam on the Tennessee River, and the other is below Melton Hill Dam on the Clinch River. Comparison of data from these NASQAN stations to waterquality data from the drainage basins upstream of the dams was made to determine if NASQAN data obtained below impoundments can be used to meet the objectives of the NASQAN program.

The following findings of this study have shown that NASQAN data obtained below impoundments may be inadequate to describe a composite picture of water quality in the accounting unit: 
Extreme concentrations of constituents that might be expected in a free-flowing strearn appear to be moderated due to storage in the reservoirs. Comparison of the ranges of constituent values obtained in study area subbasins to the ranges of values observed at the two NASQAN stations shows sub-basin data to be much more variable.

Significant water-quality differences can occur between the surface, mid-depth, and bottom of a lake or reservoir. Comparisons of data obtained above and below Watts Bar Dam suggest that the water sampled at the NASQAN station comes from stratified layers of the impoundment.

Total recoverable iron data suggests that because of adsorption to sediments in the impoundments, some constituents are not accurately described by data obtained below dams.

Relations between specific conductance and common ionic constituents were defined for several main-channel stations. Relations were also defined between the continuous specific-conductance record of the NASQAN station below Watts Bar Dam and the instantaneous observations of specific conductance obtained at upstream main channel stations of the study area. Using these specific-conductance relations, the variability of several common constituents along the main-channel system could be described. Estimates of common constituent loads at the two NASQAN stations were developed from specific-conductance relations and from duration tables of specific conductance.

Relations between water-quality constituents and flow at stations on the Clinch and Tennessee Rivers are not well defined because of regulation. Compensation for the effects of discharge prior to application of the Seasonal Kendall test for trends was therefore impossible and identification of trends in water-quality constituents caused by some process (source) change was impossible. Some water-quality trends indicated at stations on the Clinch and Tennessee Rivers might be reflections of the decreasing trend in discharge during the 1972-82 water years. Thus the stations below Watts Bar Dam and below Melton Hill Dam inadequately meet the NASQAN objective to detect and assess long-term changes in stream quality.

\section{REFERENCES CITED}

Bevans, H.E., 1980, A procedure for predicting concentrations of dissolved solids and sulfate ion in streams draining areas strip mined for coal: U.S. Geological Survey Water-Resources Investigations Report 80-764, $17 \mathrm{p}$.

Crawford, C.G., Slack, J.R., and Hirsch, R.M., 1983, Nonparametric tests for trends in water-quality data using the Stastical Analysis System: U.S. Geological Survey Open-File Report 83-550, 102 p.

Elder, J.A., and Springer, M.E., 1978, General soil map, Tennessee: U. S. Soil Conservation Service, scale 1:750,000.

Fenneman, N.M., 1938, Physiography of eastern United States: New York and London, McGraw-Hill, 714 p.

Gaydos, M.W., and others, 1982, Hydrology of area 19, eastern coal province, Tennessee: U.S. Geological Survey Water-Resources Investigations Report 81-901, 75 p.

Hardeman, W.D., 1966, Geologic map of Tennessee, east-central sheet: Tennessee Division of Geology, scale 1:250,000.

Hem, J.D., 1970, Study and interpretation of the chemical characteristics of natural water $(2 d$ ed.): U.S. Geological Survey Water-Supply Paper 1473, 363 p.

Hirsch, R.M., Slack, J.R., and Smith, R.A., 1982 Techniques of trend analysis for monthly water quality data: Water Resources Research, v. 18, no. 18, p. 107-121.

Miller, R.A., 1974, The geologic history of Tennessee: Tennessee Division of Geology Bulletin 74, $63 \mathrm{p}$.

National Technical Advisory Committee, 1968, Water-quality criteria, a report of the $\mathrm{Na}$ tional Technical Advisory Committee to the Secretary of the Interior: Washington, D. C., U.S. Government Printing Office.

Simmons, C.E., and Heath, R.C., 1979, Waterquality characteristics of streams in forested and rural areas of North Carolina: U.S. Geological Survey Water-Resources Investigations Report 79-108, 49 p.

Steele, T.D., 1974, Harmonic analysis of stream temperatures: U.S. Geological Survey Cornputer Center Contribution, Program no. B260, PB-239 016/AS, 48 p. 
Swift, L.W., and Swank, W.T., Jr., 1981, Longter $m$ responses of streamflow following clearcutting and regrowth: Hydrological Sciences Bulletin, v. 26, p. 245-256.

Tennessee Department of Public Health, 1978, Water quality management plan for the Clinch River basin: Nashville, Tennessee, Division of Water Quality Control, 89 p.

Tennessee Valley Authority, 1983, Summary of existing water, sediment, fish, and soil data in the vicinity of the Oak Ridge Reservation: Knoxville, Tennessee, Tennessee Valley Authority.

Trimble, S.W., and Carey, W.P., 1984, Sediment characteristics of Tennessee streams and reservoirs: U.S. Geological Survey Open-File Report 84-749, 32 p.
U.S. Department of Commerce, 1961, Rainfall frequency atlas of the United States: U.S. Weather Bureau Technical Paper no. 40, $115 \mathrm{p}$.

U.S. Environmental Protection Agency, 1976a, Forest Harvesting and water quality: Environmental Protection Agency Report 625/5-76$013,18 \mathrm{p}$.

----- 1976b, Erosion and sediment control surface mining in the eastern U.S.: Environmental Protection Agency Report 625/3-76-006, Part $1,102 \mathrm{p}$.

U.S. 95th Congress, 1977, Public law 95-87, 91 Statute 445, 88 p.

Wershaw, R.L., 1970, Mercury in the environment: U.S. Geological Survey Professional Paper 713, p. 29-31. 